WSRC-TR-2002-00318, Rev. 0

\title{
THERMODYNAMIC MODELING OF THE SRS EVAPORATORS: PART III. TEMPERATURE, EVAPORATION, AND COMPOSITION EFFECTS ON PROCESS CONTROL STRATEGY (U)
}

C. M. Jantzen, K.G. Brown, T.B. Edwards and J.M. Pareizs

July 23, 2002

TTP \#: SR-1-9-WT-31, Subtask D

Approved by:

W.L. Tamosaitis, Research Manager

Waste Processing Technology 
This document was prepared in conjunction with work accomplished under Contract No. DE-AC09-96SR18500 with the U. S. Department of Energy.

\section{DISCLAIMER}

This report was prepared as an account of work sponsored by an agency of the United States Government. Neither the United States Government nor any agency thereof, nor any of their employees, makes any warranty, express or implied, or assumes any legal liability or responsibility for the accuracy, completeness, or usefulness of any information, apparatus, product or process disclosed, or represents that its use would not infringe privately owned rights. Reference herein to any specific commercial product, process or service by trade name, trademark, manufacturer, or otherwise does not necessarily constitute or imply its endorsement, recommendation, or favoring by the United States Government or any agency thereof. The views and opinions of authors expressed herein do not necessarily state or reflect those of the United States Government or any agency thereof.

This report has been reproduced directly from the best available copy.

Available for sale to the public, in paper, from: U.S. Department of Commerce, National Technical Information Service, 5285 Port Royal Road, Springfield, VA 22161, phone: (800) 553-6847, fax: (703) 605-6900

email: orders@ntis.fedworld.gov

online ordering: http://www.ntis.gov/help/index.asp

Available electronically at http://www.osti.gov/bridge

Available for a processing fee to U.S. Department of Energy and its contractors, in paper, from: U.S. Department of Energy, Office of Scientific and Technical Information, P.O. Box 62, Oak Ridge, TN 37831-0062,

phone: (865)576-8401,

fax: (865)576-5728

email: $\underline{\text { reports@ adonis.osti.gov }}$ 
WSRC-TR-2002-00318, Rev. 0

Distribution Category: Unlimited

Keywords: Evaporators, activity diagrams, zeolite, $2 \mathbf{H}$ Evaporator

Retention: Permanent

\title{
THERMODYNAMIC MODELING OF THE SRS EVAPORATORS: PART III. TEMPERATURE, EVAPORATION, AND COMPOSITION EFFECTS ON PROCESS CONTROL STRATEGY (U)
}

\author{
C. M. Jantzen, K.G. Brown, T.B. Edwards and J.M. Pareizs
}

Publication Date: July 23, 2002

TTP \#: SR-1-9-WT-31, Subtask D

Approved by:

W.L. Tamosaitis, Research Manager

Waste Processing Technology 
WSRC-TR-2002-00318, Rev. 0

Savannah River Technolegy Center

Westinghouse Savannah River Company

Savannah River Site

Aiken, SC 29808

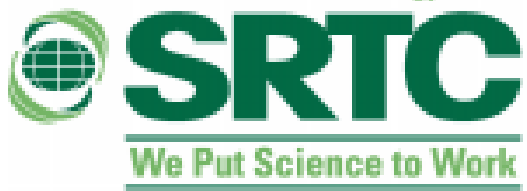

PREPARED FOR THE U.S. DEPARTMENT OF ENERGY UNDER CONTRACT NO. DE-AC09-96SR18500 
WSRC-TR-2002-00318, Rev. 0

\section{Approvals}

C. M. Jantzen, Author, Immobilization Technology

Date

$\overline{\text { W.R. Wilmarth, Technical Reviewer, Waste Processing Tech. }} \overline{\text { Date }}$

D.T. Hobbs, Technical Reviewer, Waste Processing Technology

Date

Richard E. Edwards, Manager, HLW Process Engineering

Date

E.J. Freed, Technical Reviewer, CST Engineering

Date

R.H. Spires, Manager, Immobilization Technology

Date

W.L. Tamosaitis, Manager, Waste Processing Technology

Date 


\section{WSRC-TR-2002-00318, Rev. 0}

\section{EXECUTIVE SUMMARY}

Accumulations of two solid phases (a nitrated aluminosilicate) and sodium diuranate, in the form of scale, caused the SRS $2 \mathrm{H}$ Evaporator pot to become completely inoperable in October 1999. The accumulation of the sodium diuranate phase, which selectively precipitated with the aluminosilicate phase, caused criticality concerns in the $2 \mathrm{H}$ Evaporator. In order to understand the role of steady state saturation on the scale formation, solutions processed from the SRS $2 \mathrm{H}, 2 \mathrm{~F}$, and $3 \mathrm{H}$ Evaporators were evaluated with a commercially available thermodynamic equilibrium code known as Geochemist's Workbench (GWB).

Reactive oxides, soluble silicates, and soluble aluminates in caustic solution can form a sodium aluminosilicate gel $\left(\mathrm{NAS}_{\text {gel }}\right)$ at ambient temperature when the solution stoichiometry of the aluminate and silicate species is $\sim 1: 1$. The $\mathrm{NAS}_{\text {gel }}$ converts to Zeolite-A under hydrothermal conditions similar to those existing in the SRS evaporators. The nitrated-cancrinite/sodalite formed in the SRS 2H Evaporator was found to have

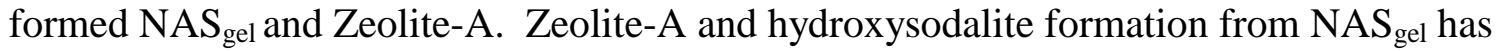
also been observed in evaporators used in the wood pulp industry while formation of $\mathrm{NAS}_{\text {gel }}$ and transformation into Zeolite- $\mathrm{A} \rightarrow$ sodalite $\rightarrow$ cancrinite has been observed in the Bayer aluminum process. Thermodynamic data developed for the pulp and aluminum processes were used to augment the database of Geochemist's Workbench.

The potential to form the $\mathrm{NAS}_{\text {gel }}$ phase in the evaporator was modeled because this phase is the primary phase from which all the other aged crystalline product species are derived. In addition, the formation of the $\mathrm{NAS}_{\text {gel }}$ phase is kinetically the most rapid step in the formation sequence [species in solution] $\rightarrow \mathrm{NAS}_{\text {gel }} \rightarrow$ Zeolite- $\mathrm{A} \rightarrow$ sodalite $\rightarrow$ cancrinite. Modeling the denser crystalline phases, which are more thermodynamically stable but less soluble than the $\mathrm{NAS}_{\text {gel }}$, would unnecessarily constrict the solution chemistry range of the SRS evaporators.

A saturation index, $\log (\mathrm{Q} / \mathrm{K})_{\text {NAS }}$, was calculated for the $\mathrm{NAS}_{\text {gel }}$ using Geochemist's Workbench. The saturation index was calculated assuming a $40 \mathrm{wt} \%$ nominal evaporation for each of the SRS evaporators $(2 \mathrm{H}, 2 \mathrm{~F}$, and $3 \mathrm{H})$. Nominal operating temperatures of $120-140^{\circ} \mathrm{C}$ were also assumed based on evaporator operational history from $1995-2001$. The $\log (\mathrm{Q} / \mathrm{K})_{\mathrm{NAS}}$ calculated for a $40 \mathrm{wt} \%$ evaporation at $120-140^{\circ} \mathrm{C}$ was regressed against the molar concentrations of $\mathrm{Al}, \mathrm{Si}$, and $\mathrm{OH}$ measured routinely in the evaporator tanks at ambient temperature, $\log \mathrm{Q}(\mathrm{NAS})_{25^{\circ} \mathrm{C}}$. A process control strategy was developed to relate the ambient $\log \mathrm{Q}(\mathrm{NAS})_{25^{\circ} \mathrm{C}}$ in the feed tank to the saturation of that feed in the evaporator pot $\left(\log (\mathrm{Q} / \mathrm{K})_{\mathrm{NAS}}\right)$ at elevated temperature after a nominal 40 wt \% evaporation.

In this study the process control strategy is expanded to different evaporation concentrations between $10 \%$ and $60 \%$ and temperatures up to $180^{\circ} \mathrm{C}$. The $\log (\mathrm{Q} / \mathrm{K})_{\mathrm{NAS}}$ is fairly independent of evaporator operating temperature in the range of $120-180^{\circ} \mathrm{C}$ based on the solubility data of the $\mathrm{NAS}_{\mathrm{gel}}$ as measured in the Bayer aluminum process. In addition, an orthogonal latin hypercube (OLH) design was used to generate compositions over this expanded evaportion and temperature space. The Geochemist's Workbench 


\section{WSRC-TR-2002-00318, Rev. 0}

results for these OLH points demonstrate that the process control model are applicable to compositions outside the range of the original evaporator solutions modeled.

Operational histories of the SRS 2H, 2F, and 3H evaporators from 2001-2002 were also reviewed. Production samples from the SRS 3H Evaporator system (January 2002) confirmed the operational process control limit previously determined based on production samples from the SRS 2F Evaporator system. 


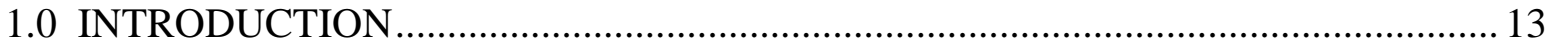

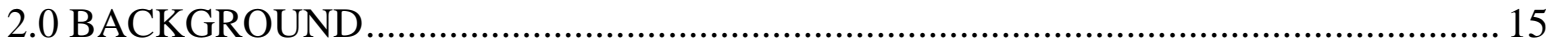

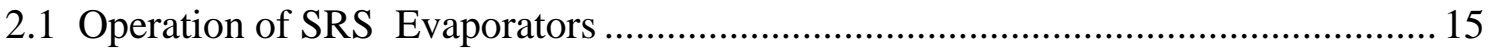

2.2 Geochemist's Workbench (GWB) ………………......................................... 16

2.3 Latin Hypercube Statistical Analysis ................................................................... 18

2.4 The Role of Kinetics in Thermodynamic Modeling ……………......................... 20

3.0 PROCESS MODELING FOR NOMINAL EVAPORATOR OPERATION ${ }^{3}$................24

4.0 RECENT ANALYTIC DATA AVAILABLE FOR EVAPORATOR MODELING .....29

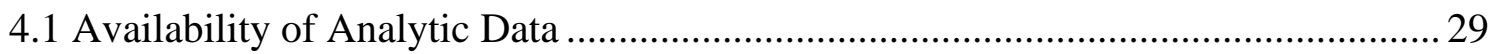

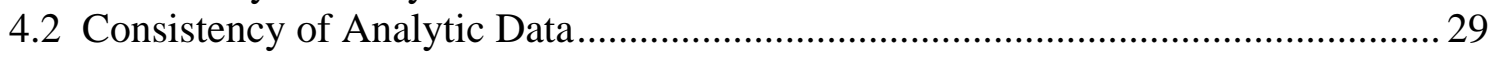

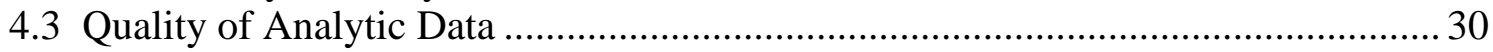

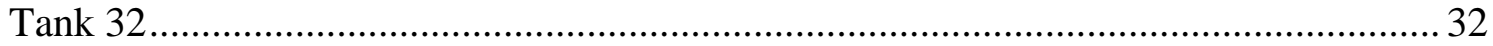

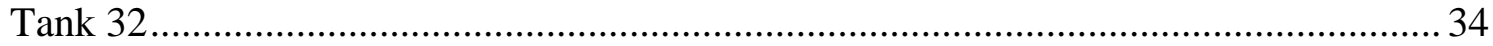

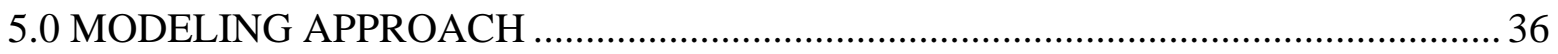

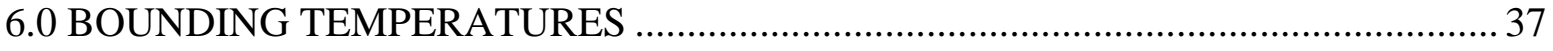

6.1 Upper and Lower Temperature Bounds ................................................................ 38

6.2 Operational Process Control Limit........................................................................... 39

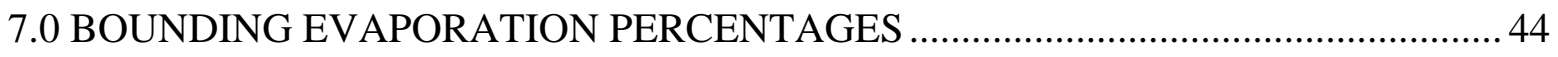

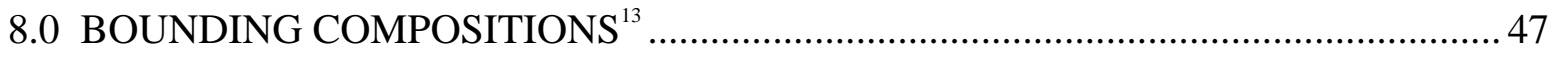

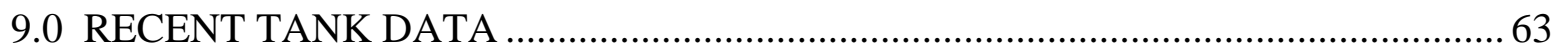

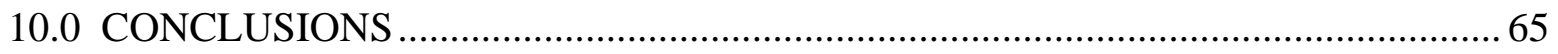

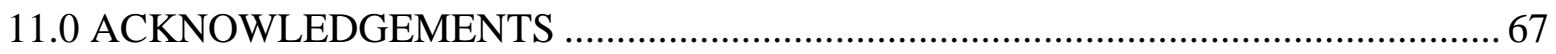

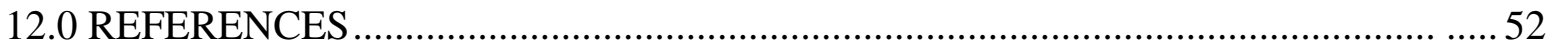


Figure 1 Scatterplot matrix for the Optimized OLH Design.

Figure 2. Typical formation and aging (densification) sequence of $\mathrm{NAS}_{\text {gel }} \rightarrow$ Zeolite$\mathrm{A} \rightarrow$ sodalite $\rightarrow$ cancrinite phases

Figure 3. Pictorial diagram showing the differences between a sol, gel, and precipitate (after references and).

Figure 4. Nominal process control model for the SRS evaporators .28

Figure 5. Temperature variation of the nominal process control model. 41

Figure 6. Difference in $\log \mathrm{Q} / \mathrm{K}$ calculation between pooled $120^{\circ} / 140^{\circ} \mathrm{C}$ and $180^{\circ} \mathrm{C} \ldots \ldots . .43$

Figure 7. Relation of $\log \mathrm{Q}(\mathrm{NAS})_{25^{\circ} \mathrm{C}}$ to percent evaporation for process control. 45

Figure 8. Evaporator model at various weight percent evaporations varying from $10 \%$ to 60

Figure 9. Bivariate Fit of $\log \mathrm{Q} / \mathrm{K}$ for $\mathrm{NAS}_{\text {gel }}$ versus $\log \mathrm{Q}(\mathrm{NAS})_{25^{\circ} \mathrm{C}}\left(\mathrm{K}_{\mathrm{sp}}\right)$ for the optimized Orthogonal Latin Hypercube model.

Figure 10. Comparison of the OLH composition space analysis at temperatures of $40^{\circ} \mathrm{C}-180^{\circ} \mathrm{C}$, at evaporations spanning zero to $80 \%$ compared to the SRS evaporator nominal model at $120-140^{\circ} \mathrm{C}$ operating temperature and $40 \%$ evaporation.

Figure 11. Recent Tank Data (February 2001-June 2002). 64 


\section{LIST OF TABLES}

Table I. Calculated $\log (\mathrm{Q} / \mathrm{K})_{\mathrm{NAS}}$ for Operational Bounds Defined By Tank 46 Process Samples

Table II. Calculated $\log (\mathrm{Q} / \mathrm{K})_{\mathrm{NAS}}$ for Historic (1992) Samples from 27

Table III. Available Tank 30 and 32 Analytic Data for Recent SRS Evaporator Operation

Table IV. Available Tank 26, 46, 43 and 38 Analytic Data for Recent SRS Evaporator Operation 33

Table V. Tank 30 and 32 Modeling Data for Recent SRS Evaporator Operation 34

Table VI. Tank 26, 46, 43 and 38 Modeling Data for Recent SRS Evaporator Operation

Table VII. Calculated $\log (\mathrm{Q} / \mathrm{K})_{\mathrm{NAS}}$ for Operating Limit Samples from Tank 46 and Tank 30 at Varying Temperature

Table VIII Percent Evaporation Vs. Ksp(NAS) Values for Process Control........................ 45

Table IX. Ranges Modeled in Part I and Part II of This Study 47

Table X. Tank Farm Bounding Regions Including Logarithmic Transformations Assumed in the OLH Statistical Analysis

Table XI. OLH Logarithm-Based Design Matrix Corresponding to the Optimized T Matrix (concentrations are molar) .....................................................................5 50

Table XII. GWB Results Corresponding to the Optimized Design Matrix .............................58

Table XIII.Recent Tank Data in the SRS 3H Evaporator System......................................... 64 
WSRC-TR-2002-00318, Rev. 0

\section{LIST OF ACRONYMS}

ACT-2: $\quad$ ACTivity Diagram Subroutine in GWB

DOE: $\quad$ United States Department of Energy

GDL: Gravity Drain Line

GWB: $\quad$ The Geochemist's Workbench Software

HLW: High Level Waste

LHS: $\quad$ Left Hand Side

LLNL: $\quad$ Lawrence Livermore National Laboratory

NAS: $\quad$ Sodium Aluminosilicate gel

OLS: $\quad$ Ordinary Least Squares

OLH: $\quad$ Orthogonal Latin Hypercube

ORNL: $\quad$ Oak Ridge National Laboratory

PNNL: $\quad$ Pacific Northwest National Laboratory

REACT: $\quad$ Reaction Path Subroutine in GWB

RHS: $\quad$ Right Hand Side

RW-0333P: DOE Level of Quality Assurance

SRS: $\quad$ Savannah River Site

SRTC: $\quad$ Savannah River Technology Center

VDS: $\quad$ Variable Depth Samples

WSRC: $\quad$ Westinghouse Savannah River Company 



\title{
THERMODYNAMIC MODELING OF THE SRS EVAPORATORS: PART III. TEMPERATURE, EVAPORATION, AND COMPOSITION EFFECTS ON PROCESS CONTROL STRATEGY (U)
}

\author{
C. M. Jantzen, K.G. Brown, T.B. Edwards, and J.M. Pareizs \\ Savannah River Technology Center \\ Westinghouse Savannah River Company \\ Aiken, South Carolina 29808
}

\subsection{INTRODUCTION}

Accumulations of two solid phases (a nitrated aluminosilicate $f$ and sodium diuranate*) formed scale deposits in the Savannah River Site (SRS) 2H Evaporator system. ${ }^{1,2}$ The aluminosilicate scale deposits caused the evaporator pot to become inoperable in October 1999. Accumulations of the diuranate phase have caused criticality concerns in the SRS $2 \mathrm{H}$ Evaporator. In Part I of this study, ${ }^{3}$ thermodynamically derived activity diagrams, also known as stability diagrams, were used on historic $2 \mathrm{H}$ feed tank (Tank 43) and drop tank (Tank 38) chemistries in order to understand the effects of tank chemistry on solids formation in the $2 \mathrm{H}$ Evaporator. Evaluation of the $2 \mathrm{~F}$ feed tank (Tank 26) and drop tank (Tank 46) chemistries evaluated in Part I of this study showed that the SRS 2F Evaporator system had not and was not near saturation with respect to aluminosilicate scale. In order to ensure that similar deposits had not and were not depositing in the SRS 3H Evaporator, a similar evaluation was performed specific to the feeds processed from Tank 32 (feed tank) and Tank 30 (drop tank) in Part II of this study.

Activity diagram representation was used to calculate if an evaporator feed tank composition fell in the formation field of the undesirable aluminosilicate species, e.g. was a given evaporator solution saturated or supersaturated with respect to the undesirable aluminosilicate species that caused scaling. Modeling the deposition of the aluminosilicates and sodium diuranate in the SRS evaporators entailed calculations in the complex Na-N-Si-Al-U-H $\mathrm{H}_{2} \mathrm{O}$ system at elevated temperatures and at high ionic strengths (I 8.5). Modeling accuracy was evaluated against the following parameters:

- $\quad$ quality of the chemical data available from the feed and drop tanks

- $\quad$ how representative the analytic dip samples from the feed and drop tank are of the feed entering the evaporator

- $\quad$ quality of the solubility data used from the literature

- $\quad$ quality of the approximations that must be made to determine the activity coefficients for high ionic strength solutions.

\footnotetext{
$f$ a mixture of nitrated cancrinite, $\mathrm{Na}_{8} \mathrm{Al}_{6} \mathrm{Si}_{6} \mathrm{O}_{24}\left(\mathrm{NO}_{3}\right)_{2} \bullet 4 \mathrm{H}_{2} \mathrm{O}$, and nitrated sodalite, $\mathrm{Na}_{8} \mathrm{Al}_{6} \mathrm{Si}_{6} \mathrm{O}_{24}\left(\mathrm{NO}_{3}\right)_{2}$

* $\mathrm{Na}_{2} \mathrm{U}_{2} \mathrm{O}_{7}$
} 
The quality of the solubility data used from the Bayer aluminum process and the paper and pulp industry and the quality of the approximations that are used to model high ionic strength solutions are discussed in Part I of this study. ${ }^{3}$ Validation of the calculation approach in simple one component systems and in the complex $\mathrm{Na}-\mathrm{N}-\mathrm{Si}-\mathrm{Al}-\mathrm{U}-\mathrm{H}_{2} \mathrm{O}$ system is also discussed in Part I of this study. ${ }^{3}$ The quality of the chemical data available for the SRS $2 \mathrm{H}$ and $2 \mathrm{~F}$ Evaporators is also discussed in Part I of this study ${ }^{3}$ while the quality of the chemical data for the SRS 3H Evaporator is discussed in Part II of this study.

A process control strategy was developed in Part I of this study ${ }^{3}$ to relate the ambient temperature chemistry in an evaporator feed tank to the saturation of that feed in the evaporator pot at elevated temperature during a nominal $40 \mathrm{wt} \%$ evaporation. In this study (Part III) the usage of this process control strategy is expanded to $10 \%, 20 \%, 30 \%$, $50 \%$, and $60 \%$ evaporation and temperatures spanning $120-180^{\circ} \mathrm{C}$. In addition, the model applicability and Geochemist's Workbench are validated with a statistically designed tank composition data set which included composition ranges far outside those modeled in Part $\mathrm{I}^{3}$ and $\mathrm{II}^{4}$ and to evaporations up to $80 \%$, and to temperatures up to $180^{\circ} \mathrm{C}$. This statistically designed validation is demonstrated via an orthogonal latin hypercube (OLH) analysis. Recent operation of the SRS $2 \mathrm{H}, 2 \mathrm{~F}$, and $3 \mathrm{H}$ evaporators is reviewed in terms of this process control strategy but the model developed in Part $\mathrm{I}^{3}$ of this study is not revised in this study.

Part IV of this study will incorporate new solubility data for the aluminosilicate phases obtained in simulated SRS evaporator solutions by researchers at the University of Southern Australia. ${ }^{5}$ This solubility data is considered more applicable to the SRS Evaporator modeling since the dissolution solution contained the constituents found in SRS solutions such as $\mathrm{NO}_{3}$ and $\mathrm{NO}_{2}$ instead of just $\mathrm{NaOH}$ solubility which was the basis of the data used from the Bayer aluminum process. The process control model from Part $\mathrm{I}^{3}$ will be revised in Part IV. In Part IV the recent SRS Evaporator data given in this study (Part III) will be included in the modeling data and all the data modeled will be based on the new solubility data for $\mathrm{NAS}_{\text {gel }}$ in SRS evaporator like high caustic solutions. The temperature and evaporation dependence of the process model will be revaluated in Part IV. Validation of the revised process control model in the complex Na-N-Si-Al-U- $\mathrm{H}_{2} \mathrm{O}$ system will be revalidated in Part IV as was done in Part I. Additional validation with designed experiments performed by researchers at the Pacific Northwest National Laboratory (PNNL) and the Oak Ridge National Laboratory (ORNL) are discussed in Part V of this study. ${ }^{6}$ 
WSRC-TR-2002-00318, Rev. 0

\subsection{BACKGROUND}

\subsection{Operation of SRS Evaporators}

For $\sim 40$ years, the SRS tank farm evaporators have run with only occasional operational problems, e.g., salt $\left(\mathrm{NaNO}_{3}\right)$ buildup has caused difficulty in draining evaporators but these deposits are water soluble and easily removed by flushing with hot water. The SRS $2 \mathrm{~F}$ and $3 \mathrm{H}$ Evaporators continue to operate with only occasional salt buildup. However, operation of the SRS $2 \mathrm{H}$ evaporator had become problematic due to the formation of aluminosilicate scale between 1997 and 1999.

A new 2H Evaporator pot was installed and began receiving waste in January 1996. From mid 1996 until August 1997 the SRS 2H Evaporator was increasingly hard to control. When the evaporator was shut down in August 1997 for cleaning, deposits of the sodium aluminosilicate and sodium uranate phases were found in the gravity drain line (GDL). ${ }^{7}$ The GDL was pressure washed in the direction of the drop tank. The line remained clean and the evaporator showed minimal deposits on the walls or in the lines from August 1997 to June 1998. In June 1998 the GDL needed to be pressure washed a second time and deposits were observed in the evaporator cone, on the vessel walls and on the warming tubes. The GDL was pressure washed in the direction of the evaporator and in the direction of the drop tank to ensure that it was clean. Operation continued, with difficulty, from June 1998 until October 1999, when the evaporator was shut down. At this time, significant accumulations of the aluminosilicate scale and sodium diuranate deposits were found on many of the exposed surfaces of the evaporator pot. The scale in the $2 \mathrm{H}$ Evaporator was cleaned using a depleted uranyl nitrate solution in August $2001^{8}$ and began operating again in October 2001.

Several important changes have been made in the handling of wastes entering the SRS evaporators in the last decade.* Prior to the mid 1990's, high activity waste was stored for $>1$ year before being processed in the evaporators so that the short lived radionuclides could decay before waste was concentrated. This also allowed any solids or colloidal species in the wastes to settle to the bottom of the tank before being processed. When the SRS reactors shut down and wastes were less radioactive, the one year hold strategy was no longer required.

In addition, the evaporators discharged to alternate drop tanks. When one drop tank was filled it was left to settle, and cool, and a second drop tank was used. Typically recycles to the feed tank were made from the passive drop tank and not from the active drop tank. This allowed any particulates or colloids in a given drop tank to settle before being recycled to the feed tank again for further concentration. The active/passive drop tank practice had to be discontinued in the early 1990's since there was no longer enough salt drop space in the concentrate receipt tanks.

\footnotetext{
* Synopsis by Kent Gilbreath, Mark Mahoney, and Thomas Caldwell (May, 2001)
} 
In 1997, the $1^{\text {st }}$ inter-area waste transfers were made between the SRS H-area and the SRS F-area waste tanks for the purpose of volume reducing the waste. This allowed comingling of wastes of different chemistries.

More recently, a decision was made to evaporate canyon and back-log waste in the $2 \mathrm{~F}$ evaporator for initial salt separation. This occurs when the hydroxide molarity exceeds 6$8 \mathrm{M}$. Then the desalted liquor is routed to the $3 \mathrm{H}$ evaporator for final dehydration, which can drive the hydroxide molarity above $12 \mathrm{M}$.

These changes in operational strategy and co-mingling of waste have caused concerns that the aluminosilicate scaling problems experienced with the operation of the SRS $2 \mathrm{H}$ Evaporator could now become system wide. Thus a process control strategy was developed $^{3}$ using Geochemist's Workbench (GWB) to prevent aluminosilicate scale formation in the SRS evaporators. Control of the aluminosilicate scale formation controls any criticality concerns caused by the adherent sodium diuranate which is partially enriched $\mathrm{U}^{235}$.

\subsection{Geochemist's Workbench (GWB)}

The Geochemist's Workbench (GWB) database was modified to include various solids including stable and metastable aluminosilicate minerals such as Zeolite-A, hydroxysodalite, NAS ${ }_{\text {gel }}$, and "mixed zeolite.", Modifications to the solid aluminate species had been made as well. ${ }^{3}$ The solubility data incorporated into the database for the aluminosilicate and aluminate species had been measured at high $\mathrm{Na}$ molarity which then allowed the GWB code to be used for modeling high Na molarity solutions such as those in the SRS evaporators. In addition the GWB software has the following attributes:

- ability to estimate activity coefficients for high ionic strength solutions such as those in the evaporator

- ability to improve the basis upon which the activity coefficients are estimated

- usage of Lawrence Livermore National Laboratory (LLNL) extensive database for minerals and aqueous species used to model the performance of waste forms in the High Level Waste (HLW) Repository

- includes sodium diuranate and aqueous uranate species

- ability to calculate the relative stability of multiple solid phases simultaneously

- ability to graphically represent the relative stability of multiple phases in terms of three parameters simultaneously on activity or stability diagrams, e.g. $\mathrm{Si}, \mathrm{Al}$, and $\mathrm{pH}$ of a solution

- ability to perform polythermal reaction paths, e.g. reaction path can vary temperature linearly from an initial to a final value so that elevated evaporator temperatures could be modeled

\footnotetext{
$\ddagger$ HLW System Plan, Rev. 12 
- ability to simulate evaporation by removing a percentage of the water from the calculation, e.g. base the calculation on $0.6 \mathrm{~kg}$ of water rather than on the default of $1 \mathrm{~kg}$ of water for a simulated $40 \mathrm{wt} \%$ evaporation

- ability to calculate a supersaturation index for a given solid phase expressed as a ratio of the reaction quotient $(\mathrm{Q})$ over the solubility product (K), e.g. $\log (\mathrm{Q} / \mathrm{K})$

- ability to calculate the amount of the solid phase (in $\mathrm{g}_{\text {(solid })} / \mathrm{kg}_{\text {(soln) }}$ ) that will form at the given supersaturation if precipitation to equilibrium proceeds.

Two subroutines in GWB were used to model the precipitation of solids in the complex $\mathrm{Na}-\mathrm{N}-\mathrm{Si}-\mathrm{Al}-\mathrm{U}-\mathrm{H}_{2} \mathrm{O}$ system pertinent to the SRS 2H Evaporator; e.g. REACT and ACT2. The REACT subroutine models equilibrium states and processes of solids in equilibrium with aqueous fluids. The program calculates the following:

- equilibrium distribution of aqueous species in a fluid

- the fluid's saturation state with respect to mineral phases

- the fugacities of the gases dissolved in the fluid

During the process control modeling of scale formation in SRS evaporators only the REACT subroutine was used. All mineral formation (precipitation) was suppressed so that a saturation index $(\log \mathrm{Q} / \mathrm{K})$ could be calculated. Positive values of $\log (\mathrm{Q} / \mathrm{K})$ are supersaturated while negative values are undersaturated with respect to the solid phase that could precipitate. 


\subsection{Latin Hypercube Statistical Analysis}

The statistical perspective of design problems involving computer experimentation, such as GWB, has been explored. , $10,11,12$ These references identify and discuss the unique aspects of this design and analysis problem. A method for generating orthogonal Latin hypercubes (OLHs)* and their advantages for such problems are presented in Reference 12. An advantage of a Latin Hypercube approach is that it facilitates each of the input variables having all portions of its range represented. ${ }^{12}$ Thus, the approach provides a "space-filling" (for the factor space of interest, i.e., the concentrations, temperature, and percent evaporation) set of design points. Also, the estimates of linear effects of all factors are uncorrelated with each other, and the orthogonal Latin hypercube designs "guarantee that the estimates of quadratic effects and bilinear interaction effects are uncorrelated with estimates of linear effects. However, the estimates of quadratic and bilinear interaction effects are correlated with each other.,"12

From Reference 12, an OLH consisting of $\mathrm{n}$ rows can be constructed when $\mathrm{n}$ is a power of 2 or a power of 2 plus 1 (i.e., $2^{\mathrm{m}}$ or $2^{\mathrm{m}}+1$ ). A method is provided in Reference 12 for constructing and optimizing such an OLH with $2 \mathrm{~m}-2$ columns. The value of $2 \mathrm{~m}-2$ must be equal to or greater than the number of factors of interest. A value of 9 was used for $\mathrm{m}$ (with $2 \mathrm{~m}-2=16$, which is greater than the 14 factors used for this study. ${ }^{f}$ A value of $\mathrm{m}=9$ leads to a value for $\mathrm{n}$ of 512 or 513 . For this design, a value of 513 was selected for $n$ since $m=9$. Thus, the interval of possible values for each input was divided into 513 equal sub-intervals.

Following the guidance provided in Reference 12, a minimax criterion was applied to random permutations of the design to provide a test matrix where the minimum Euclidean distance between any pair of design vectors is a maximum. Such an approach was used to generate the test matrix (or experimental design) to support this study. Figure 1 provides an illustration of the space filling and pairwise orthogonality of the resulting test matrix used in this study with concentrations expressed as the molar concentrations. Brown ${ }^{13}$ provides the details of the design approach.

* This class of orthogonal Latin hypercubes preserves orthogonality among columns, i.e., any two columns $\mathbf{u}$ and $\mathbf{v}$ of the OLH satisfy $\mathbf{u}^{\mathrm{T}} \mathbf{v}=0$ where $\mathbf{u}^{\mathrm{T}}$ is the transpose of $\mathbf{u}$.

$f \quad$ The 14 parameters included 12 composition parameters, temperature, and percent evaporation 18 
WSRC-TR-2002-00318, Rev. 0

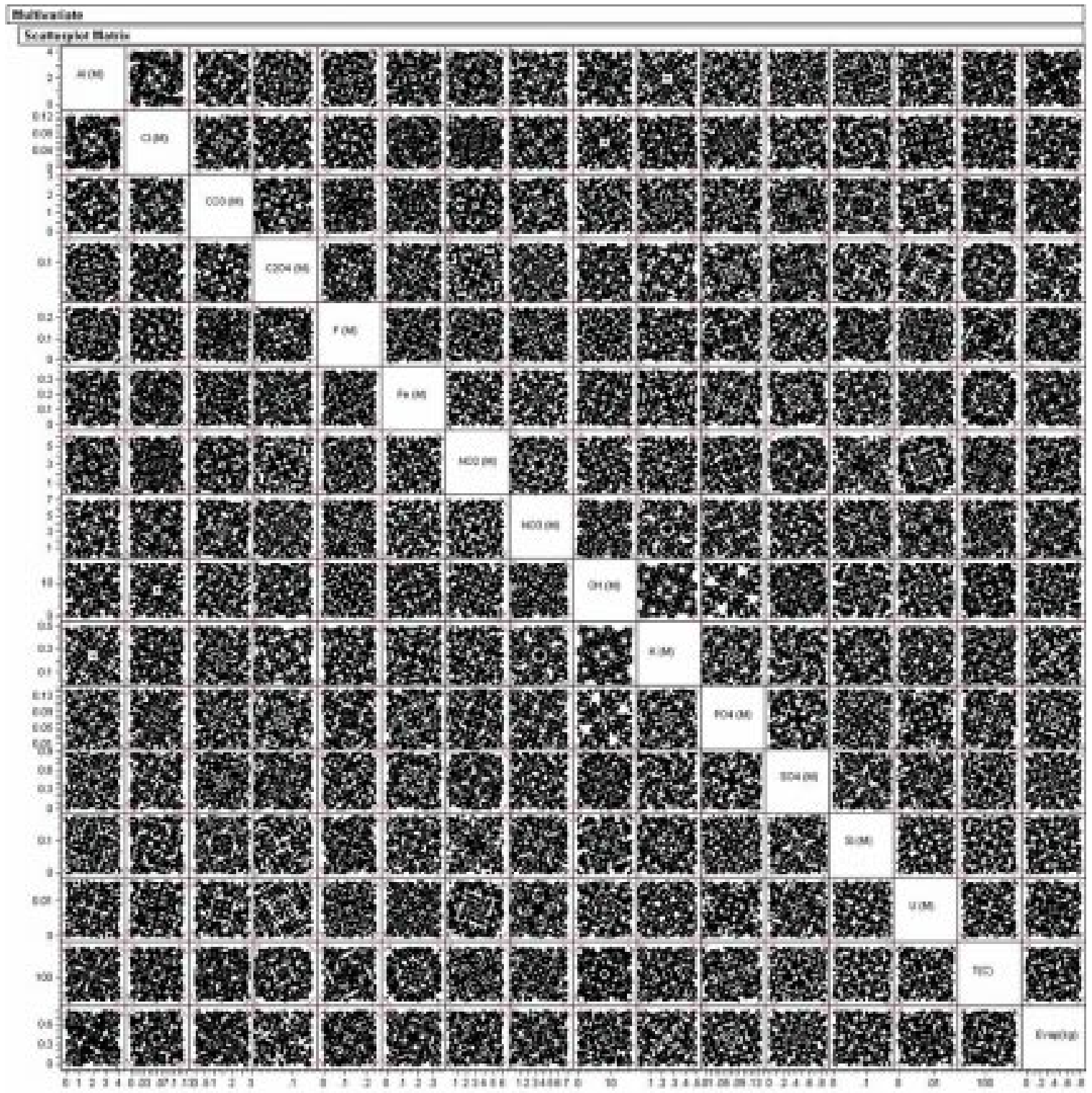

Figure 1 Scatterplot matrix for the Optimized OLH Design. 
WSRC-TR-2002-00318, Rev. 0

\subsection{The Role of Kinetics in Thermodynamic Modeling}

The Zeolite-A structure can form by any of the following mechanisms and then age to structurally related minerals such as sodalites and cancrinites:

- from a gel process where the reactants are reactive oxides, soluble silicates, and soluble aluminates in a caustic solution (Figure 2)

- from conversion of clay minerals (specifically kaolin and meta-kaolin) in the presence of soluble silicates and caustic

- by reaction of silica sols, natural $\mathrm{SiO}_{2}$, amorphous minerals, and volcanic glass in the presence of caustic (Figure 3 ). ${ }^{3}$

The gel reactions from solution and/or the silica sol reactions are the most significant of these mechanisms for SRS evaporator modeling although small traces of clay minerals could be introduced via the process water used in the evaporators. The gel reaction from solution assumed in this study takes the form:

$$
\begin{aligned}
& \mathrm{NaOH}(\mathrm{aq})+\mathrm{NaAl}(\mathrm{OH})_{4}(\mathrm{aq})+\mathrm{Na}_{2} \mathrm{SiO}_{3}(\mathrm{aq}) \stackrel{25^{\circ} \mathrm{C}}{\longrightarrow} \\
& {\left[\mathrm{Na}_{\mathrm{a}}\left(\mathrm{AlO}_{2}\right)_{\mathrm{b}}\left(\mathrm{SiO}_{2}\right)_{\mathrm{c}} \bullet \mathrm{NaOH} \bullet \mathrm{H}_{2} \mathrm{O}\right]_{\text {gel }} \stackrel{25-175^{\circ} \mathrm{C}}{\text { hydrothernal }} \longrightarrow \mathrm{Na}_{\mathrm{x}}\left[\left(\mathrm{AlO}_{2}\right)_{\mathrm{x}}\left(\mathrm{SiO}_{2}\right)_{\mathrm{y}}\right] \bullet \mathrm{mH}_{2} \mathrm{O}}
\end{aligned}
$$

Formation from silica sols would substitute an $\equiv \mathrm{Si}-\mathrm{OH}$ (silanol) term into Equation 1 instead of $\mathrm{Na}_{2} \mathrm{SiO}_{3}(\mathrm{aq})$.

Zeolites are synthesized industrially from solution using the gel process shown in Equation 1. Upon mixing sodium silicate and sodium aluminate at high $\mathrm{pH}$ an amorphous sodium aluminosilicate gel phase forms which will be abbreviated as NAS $_{\text {gel }}$. Transformation of the gel to the zeolite can take hours or days depending upon the synthesis conditions. Industrial synthesis of Zeolite-A involves solutions use of $4.0 \mathrm{M}$ $\mathrm{NaOH}$ concentrations to keep the crystallization times short and allow effective recycling of the excess $\mathrm{NaOH} .{ }^{14}$

Gels are amorphous as they are colloids in which the disperse phase has combined with the continuous phase to produce a semisolid material such as a jelly. ${ }^{15}$ As a gel dewaters or ages it will form a denser gel and/or a crystalline solid phase. This is independent of the route of formation of the gel. Whether the $\mathrm{NAS}_{\text {gel }}$ forms from solution via a hydrogel process or whether it forms from a sol (solid particles in liquid) ${ }^{16}$ via a sol-gel process, the aging sequence of the $\mathrm{NAS}_{\text {gel }}$ to denser sodalite and still denser cancrinite type species will typically follow an aging path such as that shown in Figure 2 according to Barnes, Mensah and Gerson ${ }^{17}$ and Gerson and Zheng. ${ }^{18}$ Note that the densification of the phases agrees with the following literature: 
- Bayer $^{19}$ and Ejaz ${ }^{20}$ found that the NAS gels would transform to Zeolite-A. Ejaz experimentally determined the composition of the precursor gel at $\mathrm{NaOH}$ concentrations of $3-4.5 \mathrm{M}$ to be $0.93 \mathrm{Na}_{2} \mathrm{O}: 1 \mathrm{Al}_{2} \mathrm{O}_{3}: 2.32 \mathrm{SiO}_{2}: 5.15 \mathrm{H}_{2} \mathrm{O}$.

- Barrer $^{19}$ found that the NAS gels would transform to Zeolite-A at $\mathrm{pH}$ values $>10$ in $2-3$ hours at $110^{\circ} \mathrm{C}$ (the approximate temperature of the SRS evaporators)

- Buhl and Lons ${ }^{21}$ showed that nitrated sodalite and nitrated cancrinite could best be made by starting with a Zeolite-A precursor in concentrated $\mathrm{NaOH}$ at various temperatures

- Wilmarth ${ }^{22}$ showed that the Zeolite-A forms as a precursor but the nitrated cancrinite forms on the order of $3-5$ hours at $110^{\circ} \mathrm{C}$ in simulated $2 \mathrm{H}$ Evaporator solutions

- Gasteiger et al. ${ }^{23}$ found that hydroxysodalite $\mathrm{Na}_{8}\left[\mathrm{Al}_{6} \mathrm{Si}_{6} \mathrm{O}_{24}\right](\mathrm{OH})_{2} \bullet\left(1.5 \mathrm{H}_{2} \mathrm{O}\right)$ and sodalite $\left(\mathrm{Na}_{8}\left[\mathrm{Al}_{6} \mathrm{Si}_{6} \mathrm{O}_{24}\right](\mathrm{Cl})_{2}\right)$ formation was $>99 \%$ complete in 24 hours at $95^{\circ} \mathrm{C}$ and that the sodalites formed via a Zeolite-A precursor

- Subotic, et. al..$^{24}$ demonstrated that aluminosilicate gels that have a $\mathrm{Si} / \mathrm{Al}=1$ form Zeolite-A at lower $\mathrm{NaOH}$ concentrations in solution at $85^{\circ} \mathrm{C}$ which then transforms into hydroxysodalite; at higher $\mathrm{NaOH}$ concentrations the gel can transform into hydroxysodalite without the Zeolite-A precursor formation

- Bosnar and Subotic ${ }^{25}$ demonstrated that Zeolite-A forms from an amorphous aluminosilicate precursor $\left(1.03 \mathrm{Na}_{2} \mathrm{O} \cdot \mathrm{Al}_{2} \mathrm{O}_{3} \cdot 2.38 \mathrm{SiO}_{2} \cdot 1.66 \mathrm{H}_{2} \mathrm{O}\right)$ and the Zeolite-A growth is governed by the Davies-Jones model of growth and dissolution (growth of Zeolite-A from solution coupled with dissolution of the amorphous phase); growth rate decreases with increasing alkalinity

Although nitrated sodalite and nitrated cancrinite were found in the SRS $2 \mathrm{H}$ Evaporator after long periods of time they aged in the evaporator from one of the precursor phases. In Part $\mathrm{I}^{3}$ of this study the activity diagram modeling indicated that the precursor phase most pertinent to deposition in SRS evaporators was the NAS $\mathrm{gel}_{\text {gl }}$ due to the short residence times in the evaporators. This was confirmed by kinetic testing performed at ORNL. ${ }^{26}$

Therefore, the thermodynamic steady state equilibrium of the $\mathrm{NAS}_{\mathrm{gel}}$ forms the basis for the process control model and not the crystalline equilibrium sodalite or cancrinite phases. In Part V of this study ${ }^{6}$ it will be shown that if a solution is saturated with respect to the NAS ${ }_{\text {gel }}$ phase that this phase precipitates rapidly $\left(<30\right.$ minutes at $\left.80^{\circ} \mathrm{C}\right)$. It is the function of the process control model to prevent the evaporator solutions from ever becoming saturated with respect to the $\mathrm{NAS}_{\text {gel }}$, thus preventing the precipitation of the gel. 
WSRC-TR-2002-00318, Rev. 0

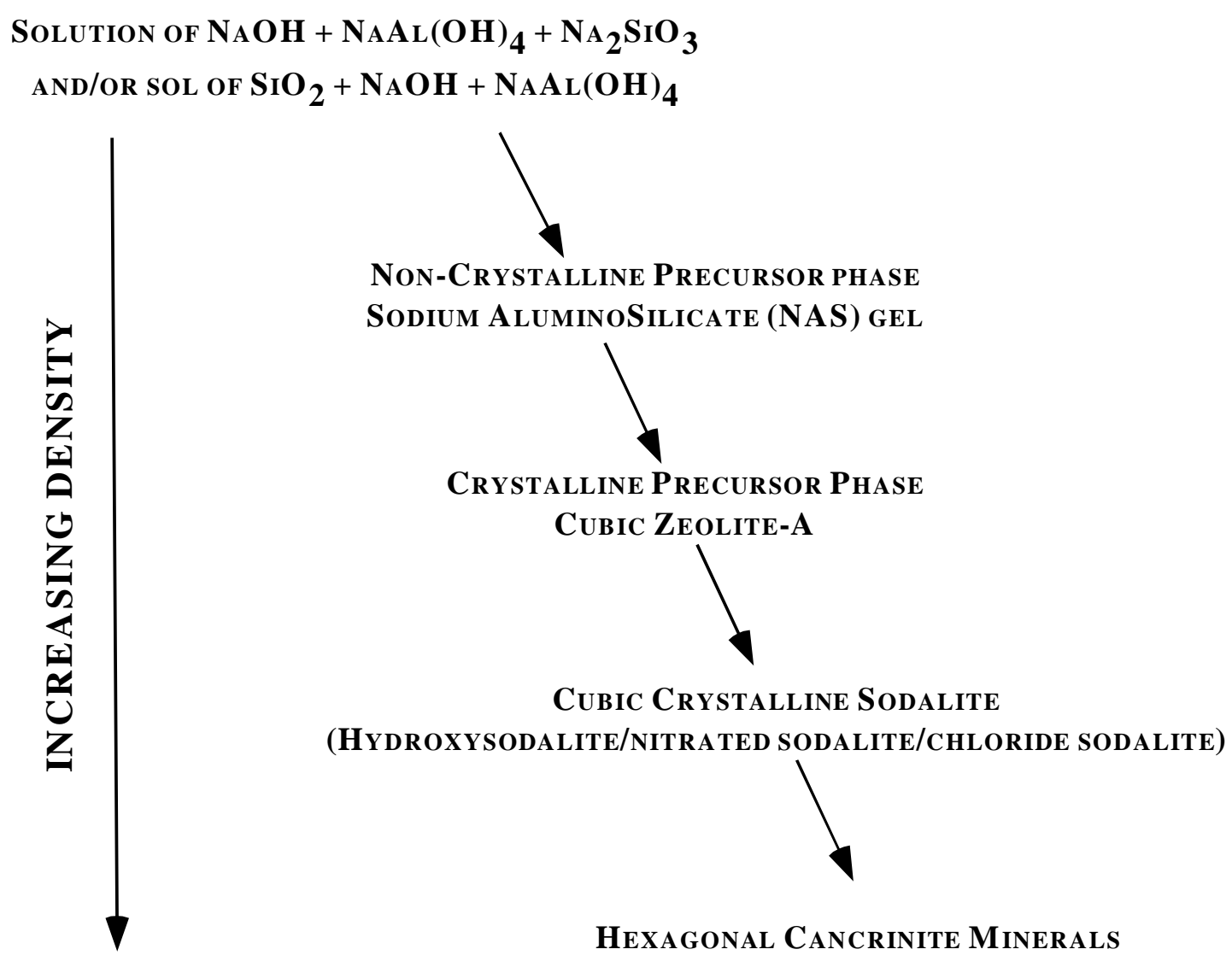

Figure 2. Typical formation and aging (densification) sequence of $\mathrm{NAS}_{\text {gel }} \rightarrow$ Zeolite-A $\rightarrow$ sodalite $\rightarrow$ cancrinite phases depending on the relative concentration of $\mathrm{OH}^{-}$, $\mathrm{Cl}^{-}, \mathrm{NO}_{3}{ }^{-}$, and/or $\mathrm{CO}_{3}{ }^{-}$in the solution in contact with the $\mathrm{NAS}_{\text {gel }}$ (after Gerson, et.al. $)^{17,18}$ 
WSRC-TR-2002-00318, Rev. 0

SOL

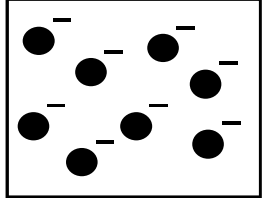

GEL

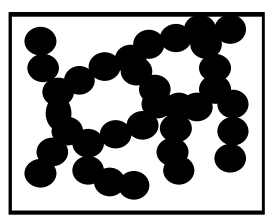

AMORPHOUS PRECIPITATE

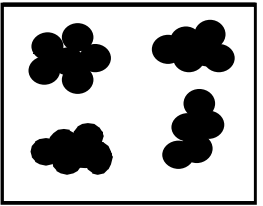

CRYSTALLINE PRECIPITATE

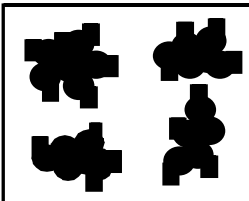

Figure 3. Pictorial diagram showing the differences between a sol, gel, and precipitate (after references 27 and 28). 


\subsection{PROCESS MODELING FOR NOMINAL EVAPORATOR OPERATION ${ }^{3}$}

The SRS evaporator model presented in Part $\mathrm{I}^{3}$ is for nominal evaporator operating conditions defined as the following:

- $40 \mathrm{wt} \%$ evaporation

- $120^{\circ} \mathrm{C}$ to $140^{\circ} \mathrm{C}$

In addition, the stoichiometry of the reaction that forms the $\mathrm{NAS}_{\text {gel }}$ from solution or from silica sols governs the process control model. The amorphous aluminosilicate gel precursor of $\mathrm{Ejaz}^{20}$ is the stoichiometry used in the SRS evaporator process model $0.93 \mathrm{Na}_{2} \mathrm{O}: 1 \mathrm{Al}_{2} \mathrm{O}_{3}: 2.32 \mathrm{SiO}_{2}: 5.15 \mathrm{H}_{2} \mathrm{O}$ ). It is very similar to that reported by Bosnar and Subotic $^{25}\left(1.03 \mathrm{Na}_{2} \mathrm{O}: \mathrm{Al}_{2} \mathrm{O}_{3}: 2.38 \mathrm{SiO}_{2}: 1.66 \mathrm{H}_{2} \mathrm{O}\right)$ but not identical (see Section 2.4).

Geochemist's Workbench assumes that the $\mathrm{NAS}_{\mathrm{gel}}$ is formed from solution species since the database does not have any solubility data for a silica sol. The equations that represent the saturation of the solution with respect to the $\mathrm{NAS}_{\text {gel }}$ are defined by the steady state equilibrium boundary on the activity diagrams which separates the field of $\mathrm{AlOOH}$ (diaspore) from the field of $\mathrm{NAS}_{\text {gel }}$ at $120^{\circ} \mathrm{C}$ as given in Equation 2.

$$
6 \text { Diaspore }+19 \mathrm{H}_{2} \mathrm{O}+6 \frac{\mathrm{Al}(\mathrm{OH})_{4}^{-}}{\mathrm{H}^{+}}+14 \mathrm{SiO}_{2}(\mathrm{aq})+12 \mathrm{Na}^{+} \Leftrightarrow \mathrm{NAS}_{\text {gel }}
$$

Equation 2 can be rewritten as

$$
\begin{aligned}
& 6 \mathrm{AlOOH}+19 \mathrm{H}_{2} \mathrm{O}+6 \mathrm{Al}(\mathrm{OH})_{4}^{-}+14 \mathrm{SiO}_{2}(\mathrm{aq})+12 \mathrm{Na}^{+} \\
& \Leftrightarrow \mathrm{Na}_{12} \mathrm{Al}_{12} \mathrm{Si}_{14} \mathrm{O}_{52} \bullet 31 \mathrm{H}_{2} \mathrm{O}+6 \mathrm{H}^{+}
\end{aligned}
$$

where the $\mathrm{NAS}_{\text {gel }}$ formula $\mathrm{Na}_{12} \mathrm{Al}_{12} \mathrm{Si}_{14} \mathrm{O}_{52} \bullet 31 \mathrm{H}_{2} \mathrm{O}$ is equivalent to $6\left(\mathrm{Na}_{2} \mathrm{O} \bullet \mathrm{Al}_{2} \mathrm{O}_{3} \bullet 2.32 \mathrm{SiO}_{2} \bullet 5.15 \mathrm{H}_{2} \mathrm{O}\right)$, the chemical composition of the $\mathrm{NAS}_{\text {gel }}$ from $\mathrm{Ejaz}^{20}$ as given above.

Use of Equation [3] for the development of the process control algorithm would have resulted in relying on a measurement of the $\mathrm{pH}$ which is inherently inaccurate at $\mathrm{pH}$ values of $>13,{ }^{7,29}$ the $\mathrm{pH}$ values reported for the SRS evaporator feeds. Since free hydroxide is routinely measured for the SRS evaporators and it is a more accurate measurement than the $\mathrm{pH}$ this term was substituted in Equation [3]. Likewise, the $\mathrm{SiO}_{2}(\mathrm{aq})$ in $\mathrm{GWB}$ represents silicic acid which can be represented in hydroxide form as $\mathrm{Si}(\mathrm{OH})_{4}$ while the $\mathrm{Na}^{+}$should be expressed as $\mathrm{NaOH}$ consistent with Equation 1 and the work of Mattigod and McGrail. ${ }^{30}$ 


$$
\begin{aligned}
& 6 \mathrm{AlOOH}+6 \mathrm{Al}(\mathrm{OH})_{4}^{-}+14 \mathrm{Si}(\mathrm{OH})_{4}(\mathrm{aq})+12 \mathrm{NaOH} \\
& \Leftrightarrow \mathrm{Na}_{12} \mathrm{Al}_{12} \mathrm{Si}_{14} \mathrm{O}_{52} \bullet 31 \mathrm{H}_{2} \mathrm{O}+15 \mathrm{H}_{2} \mathrm{O}+6 \mathrm{OH}^{-}
\end{aligned}
$$

Rewriting Equation 4 in terms of the species routinely measured in the SRS Evaporator feed tanks, e.g. $\mathrm{Al}(\mathrm{M}), \mathrm{Si}(\mathrm{M}), \mathrm{OH}(\mathrm{M})$, was shown ${ }^{3}$ to represent the formation of the

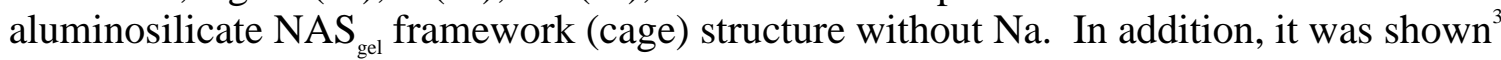
that there was a high statistical co-linearity between $\mathrm{Na}$ and $\mathrm{OH}$ in SRS evaporator solutions. Thus Equation 4 could be rewritten without the $\mathrm{NaOH}$ term:

$6 \mathrm{AlOOH}+6 \mathrm{Al}(\mathrm{OH})_{4}^{-}+14 \mathrm{Si}(\mathrm{OH})_{4}(a q) \Leftrightarrow \mathrm{Al}_{12} \mathrm{Si}_{14} \mathrm{O}_{46} \bullet 31 \mathrm{H}_{2} \mathrm{O}+9 \mathrm{H}_{2} \mathrm{O}+6 \mathrm{OH}^{-}$

The $\mathrm{K}_{\mathrm{sp}}$ for this reaction is

$$
K_{s p}\left(N A S_{g e l}\right)=\frac{\left[\mathrm{NAS}_{g e l}\right]\left[\mathrm{OH}^{-}\right]^{6}\left[\mathrm{H}_{2} \mathrm{O}\right]^{9}}{[\mathrm{AlOOH}]^{6}\left[\mathrm{Al}(\mathrm{OH})_{4}^{-}\right]^{6}\left[\mathrm{Si}(\mathrm{OH})_{4}\right]^{14}}
$$

Equation [6] can be further simplified since the $\mathrm{NAS}_{\text {gel }}$ and the water in the numerator are in their standard states and equal to 1 as shown in Equation [7]

$$
K_{s p}\left(\mathrm{NAS}_{g e l}\right)=\frac{\left[\mathrm{OH}^{-}\right]^{6}}{[\mathrm{AlOOH}]^{6}\left[\mathrm{Al}(\mathrm{OH})_{4}^{-}\right]^{6}\left[\mathrm{Si}(\mathrm{OH})_{4}\right]^{14}}
$$

or in logarithmic form

$$
\begin{aligned}
& \log K_{s p}\left(\mathrm{NAS}_{g e l}\right)=6 \log \left[\mathrm{OH}^{-}\right]-6 \log [\mathrm{AlOOH}]-6 \log \left[\mathrm{Al}(\mathrm{OH})_{4}{ }^{-}\right] \\
& -14 \log \left[\mathrm{Si}(\mathrm{OH})_{4}\right]
\end{aligned}
$$

Rewriting Equation 8 in terms of the species measured in the SRS Evaporator feed tanks, e.g. $\mathrm{Al}(\mathrm{M}), \mathrm{Si}(\mathrm{M}), \mathrm{OH}(\mathrm{M})$, multiplying both sides by -1 , and assuming that the $\mathrm{Al}$ from $\mathrm{AlOOH}$ exists in an aqueous form because diaspore is not kinetically favored to form in the short evaporator residence times gives the following equation:

$$
-\log \mathrm{Q}\left(\mathrm{NAS}_{\mathrm{gel}}\right)_{25^{\circ} \mathrm{C}}=12 \log [\mathrm{Al}(\mathrm{M})]+14 \log [\mathrm{Si}(\mathrm{M})]-6 \log [\mathrm{OH}(\mathrm{M})]
$$

Equation [9] represents the formation of the aluminosilicate "cage" structure of the $\mathrm{NAS}_{\text {gel }}$. Basing the SRS evaporator process control model on Equation [9] allowed an ordinary least squares (OLS) correlation of the measured ambient tank concentrations to saturation of those solutions in the evaporator pot after a $40 \mathrm{wt} \%$ nominal evaporation (Figure 4). The simplified model is based only on three chemical parameters that are routinely measured in the tank farm, e.g. $\log [\mathrm{Al}(\mathrm{M})], \log [\mathrm{Si}(\mathrm{M})])$, and $\log [\mathrm{OH}(\mathrm{M})]$. The OLS correlation between evaporator pot saturation and ambient tank chemisty is given in Equation [10] and defined as the nominal SRS evaporator model as derived in Part I. ${ }^{3}$ 


$$
\begin{aligned}
& \log (Q / K)_{N A S 120-140^{\circ} \mathrm{C} / 40 \% \text { evap }}=36.4450+0.9696(12 \log [\operatorname{Al}(M)]+14 \log [\operatorname{Si}(M)] \\
& -6 \log [O H(M)]
\end{aligned}
$$

where the tank chemistry is expressed on the RHS of Equation 10, hereafter referred to as $\log \mathrm{Q}(\mathrm{NAS})_{25^{\circ} \mathrm{C}}$, and the supersaturation index of the feed in the evaporator pot on the LHS is hereafter referred to as $\log (\mathrm{Q} / \mathrm{K})_{\mathrm{NAS}}$. The $\mathrm{R}^{2}$ of the OLS correlation given by Equation [10] is 0.90 based on data pooled from both F-area laboratory and SRTC. The SRTC analytic measurements are shown in pink and the F-Area laboratory data in gray.

The nominal process model from Part $\mathrm{I}^{3}$ of this study in Figure 4 can be compared to the solubility product criteria, [Al] $*[\mathrm{Si}]$ in $\mathrm{M}^{2} \sim 10^{-4}$, recently used by Wilmarth ${ }^{30,37}$ to determine the acceptability of feed tank solutions for processing in the SRS $3 \mathrm{H}$ Evaporator. The Wilmarth solubility product is shown in Figure 4 compared to recent operational data for Tank 46F. Recent Tank 46F samples have been measured by SRTC and so the apparent operational limit shown in Figure 4 is based on qualified Si data (sample FTF-046 from the $2 \mathrm{~F}$ drop tank; $\log \mathrm{Q}(\mathrm{NAS})_{25^{\circ} \mathrm{C}}$ of -43.3 . Additional data supporting this limit will be discussed in Section 6.2. Sample FTF-046 corresponds to a $\log (\mathrm{Q} / \mathrm{K})_{\mathrm{NAS}}$ limit of -5.5 based on Equation 10. It should be noted that due to random error in the model and the data the upper $95 \%$ error band in the nominal correlation could be as high as saturation, e.g. a $\log (\mathrm{Q} / \mathrm{K})_{\mathrm{NAS}}$ of close to zero, -0.576 , (see Table I).

As qualified Si data is accumulated this apparent operational limit may be moved. There are several historic samples from 1992 on Figure 4 that have $\log \mathrm{Q}(\mathrm{NAS})_{25^{\circ} \mathrm{C}}$ values more positive than -43.3 . The pink symbols $Y$ (Tank 30), square (Tank 43) and Z (Tank 26) indicate the analyses were performed at SRTC. However, these samples had not been filtered, e.g. contributions from colloidal sources of Si had not been accounted for. The $\log (\mathrm{Q} / \mathrm{K})_{\mathrm{NAS}}$ values for these samples for the nominal temperature and evaporation is given in Table II and demonstrates that operational limits, within the error of the modeling, may be more positive than $\log (\mathrm{Q} / \mathrm{K})_{\mathrm{NAS}}=-5.5$. This is not unreasonable as silicate solutions can be $>200 \%$ supersaturated at temperature and not precipitate until the solutions are cooled. ${ }^{31}$ However, the apparent operational limit is currently set conservatively $\log \mathrm{Q}(\mathrm{NAS})_{25^{\circ} \mathrm{C}}$ of -43.3 corresponding to $\log (\mathrm{Q} / \mathrm{K})_{\mathrm{NAS}}$ of -5.50 based on reliable Si analyses as discussed in Section 4.3. 
WSRC-TR-2002-00318, Rev. 0

Table I. Calculated $\log (\mathrm{Q} / \mathrm{K})_{\mathrm{NAS}}$ for Operational Errors Defined By Tank 46 Process Samples

\begin{tabular}{|c|l|l|}
\hline Temperature & \multicolumn{1}{|c|}{ Equation Used } & $\begin{array}{c}\text { Log }(\mathbf{Q} / \mathbf{K})_{\text {NAS }} \text { for } \\
\text { Sample FTF-046 }\end{array}$ \\
\hline $120 / 140^{\circ} \mathrm{C}$ pooled data & Upper 95\% Error & -0.576 \\
\hline $120 / 140^{\circ} \mathrm{C}$ pooled data & Equation 10 & -5.501 \\
\hline $120 / 140^{\circ} \mathrm{C}$ pooled data & Lower $95 \%$ Error & -10.426 \\
\hline
\end{tabular}

Table II. Calculated Log $(\mathrm{Q} / \mathrm{K})_{\mathrm{NAS}}$ for Historic (1992) Samples from Tanks 30, 43, and 26

\begin{tabular}{|l|l|l|l|l|}
\hline Temperature & Equation Used & $\begin{array}{c}\text { Log } \\
(\mathbf{Q} / \mathbf{K})_{\text {NAS }} \\
\text { Sample 199672 } \\
(\text { Tank 30) }\end{array}$ & $\begin{array}{c}\text { Log } \\
(\mathbf{Q} / \mathbf{K})_{\text {NAS }} \\
\text { Sample 199432 } \\
(\text { Tank 43) }\end{array}$ & $\begin{array}{c}\text { Log } \\
(\mathbf{Q} / \mathbf{K})_{\text {NAS }} \\
\text { Sample 193275 } \\
(\text { Tank 26) }\end{array}$ \\
\hline $120 / 140^{\circ} \mathrm{C}$ pooled data & Upper 95\% Error & -1.458 & +3.693 & +3.044 \\
\hline $120 / 140^{\circ} \mathrm{C}$ pooled data & Equation 10 & -6.380 & -1.256 & -1.901 \\
\hline $120 / 140^{\circ} \mathrm{C}$ pooled data & Lower 95\% Error & -11.302 & -6.205 & -6.845 \\
\hline
\end{tabular}




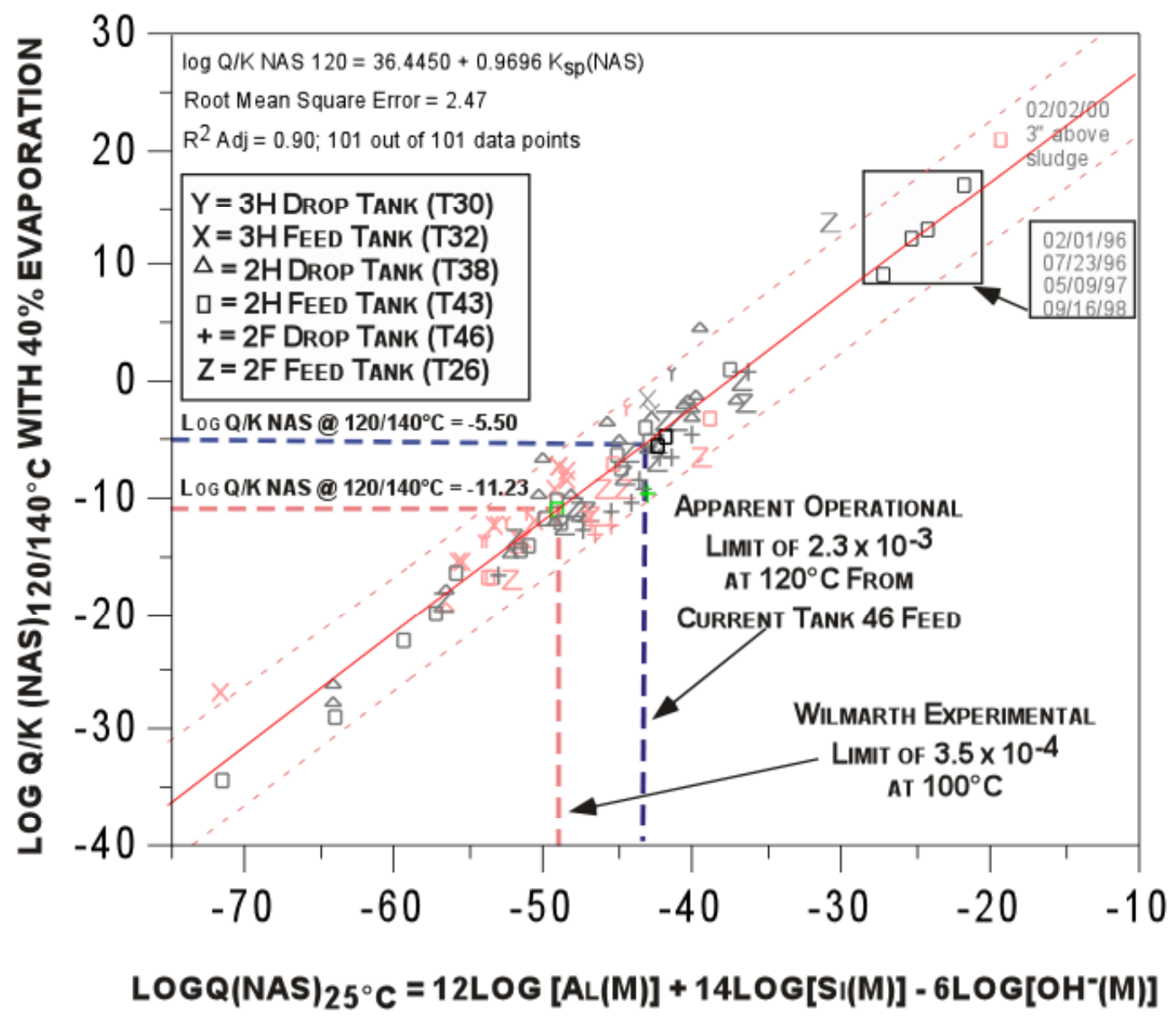

Figure 4. Nominal process control model for the SRS evaporators. This model is based on the equilibrium between diaspore and $\mathrm{NAS}_{\text {gel }}$ represented on the activity diagrams in Part $\mathrm{I}^{3}$ and Equations [5] to [10]. It provides an OLS correlation between ambient feed tank chemistry and saturation of these solutions in the evaporator after a $40 \mathrm{wt} \%$ nominal evaporation in the $120-140^{\circ} \mathrm{C}$ temperature range. The intercept includes the evaporation term, the numeric conversions from molar to molal concentrations, corrections for the activity coefficients, and temperature corrections for the solubility of the solid species, diaspore and $\mathrm{NAS}_{\text {gel }}$ The stoichiometry of the x-axis is defined by the stoichiometry of the $\mathrm{NAS}_{\text {gel }}$ and cannot be applied to phases with other stoichiometries. 
WSRC-TR-2002-00318, Rev. 0

\subsection{RECENT ANALYTIC DATA AVAILABLE FOR EVAPORATOR MODELING}

\subsection{Availability of Analytic Data}

A compilation of molar chemical analyses for Tanks 30, 32, 26, 46, 43, and 38 appears in Table III and Table IV for the time period February 2001 to June 2002. This recent tank data is discussed in this study (but not used in modeling) while previous tank data is modeled in Part $\mathrm{I}^{3}$ and Part II. ${ }^{4}$ As with the previous studies there were sparse and incomplete data in the tank farm historic records. Data for several cations were missing from the tank farm historic records for minor cation species such as $\mathrm{Fe}$ and $\mathrm{K}$, etc. In these cases $1 / 2$ the instrument detection limit was substituted assuming that a small concentration below the detection limit was probably present. This accounts for errors of 100-200\% for a concentration at or near the instrument detection limit. Na analyses, when available, were added into Table III and Table IV using data from two reports by Wilmarth. ${ }^{32,33}$ Conversely, Wilmarth did not analyze for the cation $\mathrm{K}^{+}$nor several anions, e.g. $\mathrm{Cl}, \mathrm{CO}_{3}^{2-}, \mathrm{F}, \mathrm{PO}_{4}^{3-}, \mathrm{SO}_{4}^{2-}$. When minor anion species such as these were missing, $1 / 2$ the instrument detection limit was substituted in the same manner as for missing minor cation constituents.

All available data modeled was measured in the laboratory at $25^{\circ} \mathrm{C}$ regardless of the tank temperature at the time it was sampled. Tank temperatures can vary from $40^{\circ} \mathrm{C}$ to $75^{\circ} \mathrm{C}$ but this cannot be accounted for during measurement. All measurements from 1992-2002 have been modeled by consistently using analyses measured at $25^{\circ} \mathrm{C}$.

\subsection{Consistency of Analytic Data}

In order to use the chemical analyses compiled in Table III and Table IV for modeling, the data had to be made internally consistent, e.g., anion and cation charges were balanced. Since few measured $\mathrm{Na}^{+}$molarities were available no adjustments were made to the molarities of the three principal anions, $\mathrm{OH}^{-}, \mathrm{NO}_{3}{ }^{-}$, and $\mathrm{NO}_{2}{ }^{-}$to balance against measured $\mathrm{Na}+$ concentrations. The charge balance calculations assumed that each ionic species was present in its most prevalent valence state; most importantly, Al was modeled as $\mathrm{Al}(\mathrm{OH})_{4}{ }^{-}$.

In order to account for the effect of temperature on solution densities so that the data in Table III and Table IV could be evaluated at different temperatures, molar concentrations were converted to molalities (Table V and Table VI). The molalities are based on calculated solution densities (Equation 11a). ${ }^{34}$ The solution densities were calculated from a calculated $\mathrm{Na}^{+}$molarity, $\left[\mathrm{Na}^{+}\right]_{\text {calc }}$, using Equation $11 \mathrm{~b}$ derived by Walker and Coleman ${ }^{34}$ for H-Canyon waste solutions at $25^{\circ} \mathrm{C}$. 
WSRC-TR-2002-00318, Rev. 0

$$
m=M\left(\frac{\text { weight solution }}{(\text { weight solution }- \text { total weight solutes })}\right)\left(\frac{1}{\text { density }_{\text {calc }}}\right)
$$

where $\mathrm{m}=$ molality

$\mathrm{M}=$ molarity

$$
\begin{gathered}
\text { weight solutes }=\frac{\text { dissolved solids }(\mathrm{g} / \mathrm{L})}{1000 \mathrm{~L}} \\
\qquad \begin{array}{c}
\mathrm{Al}(\mathrm{OH})_{4}^{-}+\mathrm{Cl}^{-}+\mathrm{CO}_{3}^{-2}+\mathrm{C}_{2} \mathrm{O}_{4}^{-2}+\mathrm{F}^{-}+\mathrm{NO}_{2}^{-}+\mathrm{NO}_{3}^{-} \\
\text {dissolved solids }=+\mathrm{OH}^{-}+\mathrm{PO}_{4}^{-3}+\mathrm{SO}_{4}^{-2}+\mathrm{Fe}(\mathrm{OH})_{4}^{-}+\mathrm{K}^{+}+\mathrm{H}_{2} \mathrm{SiO}_{4}^{-2}+ \\
\mathrm{UO}_{2}(\mathrm{OH})_{\frac{7}{3}}+\left[\mathrm{Na}_{\text {calc }}^{+}\right]
\end{array} \\
\text {density }_{\text {calc }} \equiv \rho=1.0133+0.040469\left[\mathrm{Na}^{+}\right]_{\text {calc }}
\end{gathered}
$$

where $\rho$ is the calculated solution density in $\mathrm{g} / \mathrm{cm}^{3}$ and $\left[\mathrm{Na}^{+}\right]_{\text {calc }}$ is the calculated molar $\mathrm{Na}^{+}$concentration from Equation 11c.

$$
\begin{aligned}
& \mathrm{Na}_{\text {calc }}^{+}=\mathrm{NaAl}(\mathrm{OH})_{4}+\mathrm{NaCl}+\mathrm{Na}_{2} \mathrm{CO}_{3}+\mathrm{Na}_{2} \mathrm{C}_{2} \mathrm{O}_{4}+\mathrm{NaF}+ \\
& \mathrm{NaNO}_{2}+\mathrm{NaNO}_{3}+\mathrm{NaOH}+\mathrm{Na}_{3} \mathrm{PO}_{4}+\mathrm{Na}_{2} \mathrm{SO}_{4}+\mathrm{NaFe}(\mathrm{OH})_{4}^{-} \\
& -\mathrm{KOH}+\mathrm{Na}_{2} \mathrm{H}_{2} \mathrm{SiO}_{4}+\mathrm{Na}\left(\mathrm{UO}_{2}\right)_{3}(\mathrm{OH})_{7}
\end{aligned}
$$

The molal contributions from $\mathrm{CO}_{3}^{-2}$ and $\mathrm{C}_{2} \mathrm{O}_{4}^{-2}$ were summed as a total $\mathrm{CO}_{3}^{-2}$ contribution, e.g. one mole of $\mathrm{C}_{2} \mathrm{O}_{4}^{-2}$ was considered to be two moles of $\mathrm{CO}_{3}^{-2}$ since Geochemist's Workbench can only accommodate one carbon species at a time. The $\mathrm{NO}_{2}^{-}$and $\mathrm{NO}_{3}^{-}$ were summed as $\mathrm{NO}_{3}$ - since Geochemist's Workbench can only accommodate one nitrogen species at a time.

In addition to reporting molar concentrations, Table III and Table IV compare calculated and measured solution densities. Solution densities were calculated from Equation $11 \mathrm{~b}$. Generally, measured and calculated densities agreed within 2-3\%. Several comparisons are as high as $9 \%$. It was assumed that these density measurements were in error but the actual measured values are shown in Table III and Table IV for comparison.

\subsection{Quality of Analytic Data}

The SRTC and the F-area laboratory both analyzed samples taken between February 2001 and June 2002. The two laboratories never measured the same sample taken on the same day so no comparisons of the analytic bias between the two laboratories can be made for this set of data. However, in Parts $\mathrm{I}^{3}$ and Part $\mathrm{II}^{4}$ of this study it was shown that the $210 \mathrm{X}$ 
dilution performed by the F-area laboratory always caused their Si analyses to be biased high by $\sim 7 \mathrm{X}$ compared to those of SRTC.

SRTC has developed a method by which the entire sample $(70 \mathrm{~mL})$ is filtered so that the total amount of Si (both soluble and colloidal) can be more accurately determined. The filtrate, representing the soluble silica, is homogeneous and can be accurately measured by ICP. The colloidal silica on the filter is dissolved and measured separately. The two are added together for a final total silica analysis that is representative of the entire sample $^{32,33}$ rather than a few milliliters of solution in a pipette. This is the method used to determine the silica for all samples beginning with HTK in Table III and Table IV.

Recently, Coleman ${ }^{35}$ has tested a spectrophotometric method from the 1920's that uses molybdic acid to analyze simultaneously for the monosilicic acid in solution, the polysilicic acids, and colloids. Coleman's analyses have verified Wilmarth's analytic results. Because of the high bias in the F-area laboratory Si analyses, only the Si analyses reported by Wilmarth were used for modeling in Part $\mathrm{I}^{3}$ and Part $\mathrm{II}^{4}$ of this study. The recent tank data discussed in Section 9.0 of this study is overlain on the model from Part I of this study. The recent data was not used in this study to generate a new model. The recent data was used only for confirmatory understanding of the recent SRS Evaporator operations.

It was noted in Part $\mathrm{I}^{3}$ and Part II $^{4}$ of this study that the evaporator feed tanks are stratified and that there are issues with how representative the dip samples used in modeling are of the entire tank contents. In Part I and Part II of this study, it was shown that the dip samples were fairly representative of the tank chemistry by comparing the modeling results from Variable Depth Samples (VDS) to the results of dip samples taken from the same tanks on the same days. Although there was some variation in the position of the VDS samples and the dip samples taken on the same day, the variation was not significant to the modeling (Table III shows triplicate samples taken on the same date from various heights within Tanks 30 and 32; the corresponding $\log \mathrm{Q}(\mathrm{NAS})_{25^{\circ} \mathrm{C}}$ are shown not to vary significantly in Table XII). This will be discussed in more detail in Sections 6.2 and 9.0 . 
WSRC-TR-2002-00318, Rev. 0

Table III. Available Tank 30 and 32 Analytic Data for Recent SRS Evaporator Operation

\begin{tabular}{|c|c|c|c|c|c|c|c|c|c|c|c|c|c|c|c|c|c|c|c|c|c|}
\hline Date & $\begin{array}{l}\text { Description/ } \\
\text { Reference }\end{array}$ & $\begin{array}{l}\text { Height } \\
\text { (inchs) }\end{array}$ & $\begin{array}{c}\mathrm{Al} \\
(\mathrm{M})\end{array}$ & $\begin{array}{c}\text { Cl } \\
(\mathbf{M})\end{array}$ & $\begin{array}{l}\mathrm{CO}_{3} \\
(\mathrm{M})\end{array}$ & $\begin{array}{l}\mathrm{C}_{2} \mathbf{O}_{4} \\
(\mathbf{M})\end{array}$ & $\begin{array}{c}\mathbf{F} \\
(\mathbf{M})\end{array}$ & $\begin{array}{l}\mathrm{NO}_{2} \\
(\mathrm{M})\end{array}$ & $\begin{array}{l}\mathrm{NO}_{3} \\
(\mathrm{M})\end{array}$ & $\begin{array}{l}\mathbf{O H} \\
(\mathbf{M})\end{array}$ & $\begin{array}{l}\mathrm{PO}_{4} \\
(\mathrm{M})\end{array}$ & $\begin{array}{l}\mathrm{SO}_{4} \\
(\mathbf{M})\end{array}$ & $\begin{array}{c}\mathbf{F e} \\
(\mathbf{M})\end{array}$ & $\begin{array}{c}\mathbf{K} \\
(\mathbf{M})\end{array}$ & $\begin{array}{c}\mathbf{S i} \\
(\mathbf{M})\end{array}$ & $\begin{array}{c}\mathbf{U} \\
(\mathbf{M})\end{array}$ & $\begin{array}{c}\mathbf{N a} \\
\text { Calc } \\
(\mathbf{M})\end{array}$ & $\begin{array}{c}\text { Na } \\
\text { Meas } \\
(\mathbf{M}) \\
\end{array}$ & $\begin{array}{r}\text { wt } \\
\text { salt, } \\
\text { g/L }\end{array}$ & $\begin{array}{c}\text { Dens } \\
\text { calc } \\
\mathrm{g} / \mathrm{ml}\end{array}$ & $\begin{array}{c}\text { Dens } \\
\text { meas } \\
\text { g/ml }\end{array}$ \\
\hline \multicolumn{22}{|c|}{ Tank 30} \\
\hline $12 / 29 / 01$ & . & $p$ & 0.7 & $60 \mathrm{E}-03$ & $1.60 \mathrm{E}-01$ & $82 \mathrm{E}-03$ & $70 \mathrm{E}-03$ & 2.09 & 38 & 5.46 & 40E-03 & 1.77E-02 & $0.00 \mathrm{E}+00$ & $70 \mathrm{E}-02$ & $.00 \mathrm{E}-04$ & $1.53 \mathrm{E}-05$ & 10.97 & & 70.25 & 1.46 & 1.43 \\
\hline $10 / 21 / 01$ & -1 & $W_{P}$ & 0.1 & $1.44 \mathrm{E}-03$ & $5.00 \mathrm{E}-03$ & $8.00 \mathrm{E}-03$ & $6.10 \mathrm{E}-03$ & 0.51 & .70 & 1.22 & $.70 \mathrm{E}-03$ & $1.94 \mathrm{E}-02$ & $0.00 \mathrm{E}+00$ & $3.00 \mathrm{E}-03$ & $1.50 \mathrm{E}-03$ & $8.03 \mathrm{E}-07$ & 2.60 & & 60.18 & 1.12 & 1.12 \\
\hline $08 / 16 / 01$ & 820 & dip & 0.39 & $7.20 \mathrm{E}-03$ & $5.00 \mathrm{E}-03$ & $2.82 \mathrm{E}-03$ & $9.05 \mathrm{E}-03$ & 2.98 & 2.37 & 5.68 & $4.10 \mathrm{E}-03$ & $3.81 \mathrm{E}-03$ & $0.00 \mathrm{E}+00$ & $1.22 \mathrm{E}-03$ & $8.00 \mathrm{E}-04$ & $9.50 \mathrm{E}-06$ & 11.47 & & 82.79 & 1.48 & 1.49 \\
\hline $05 / 30 / 01$ & 200154415 & dip & 0.39 & $1.44 \mathrm{E}-03$ & $5.00 \mathrm{E}-03$ & $2.82 \mathrm{E}-03$ & $1.20 \mathrm{E}-02$ & 1.43 & 2.02 & 2.71 & $5.50 \mathrm{E}-03$ & $4.80 \mathrm{E}-02$ & $0.00 \mathrm{E}+00$ & $3.40 \mathrm{E}-02$ & $2.50 \mathrm{E}-03$ & $1.82 \mathrm{E}-05$ & 6.66 & & 434.59 & 1.28 & 1.34 \\
\hline $1 / 02$ & HTK- $480^{32}$ & VDS & 1.1 & $1.49 \mathrm{E}-02$ & $5.00 \mathrm{E}-03$ & $2.85 \mathrm{E}-03$ & $2.65 \mathrm{E}-03$ & 1.72 & 1.26 & 9.73 & $9.10 \mathrm{E}-03$ & $1.59 \mathrm{E}-02$ & $5.59 \mathrm{E}-04$ & $6.10 \mathrm{E}-02$ & $1.64 \mathrm{E}-03$ & $3.11 \mathrm{E}-05$ & 13.85 & 13.61 & 751.68 & 1.57 & \\
\hline $1 / 02$ & HTK- $481^{32}$ & VDS & 0.6 & $1.49 \mathrm{E}-02$ & $5.00 \mathrm{E}-03$ & $2.85 \mathrm{E}-03$ & $2.65 \mathrm{E}-03$ & 1.76 & 1.26 & 9.42 & $9.10 \mathrm{E}-03$ & $1.59 \mathrm{E}-02$ & $5.59 \mathrm{E}-04$ & $6.10 \mathrm{E}-02$ & $2.85 \mathrm{E}-03$ & $3.11 \mathrm{E}-05$ & 13.08 & 13.15 & 683.21 & 1.54 & \\
\hline $1 / 02$ & HTK- $482^{32}$ & VDS & 1.1 & $1.49 \mathrm{E}-02$ & $5.00 \mathrm{E}-03$ & $2.85 \mathrm{E}-03$ & $2.65 \mathrm{E}-03$ & 1.92 & 1.37 & 9.58 & $9.10 \mathrm{E}-03$ & $1.59 \mathrm{E}-02$ & $5.59 \mathrm{E}-04$ & $6.10 \mathrm{E}-02$ & $2.67 \mathrm{E}-03$ & $3.11 \mathrm{E}-05$ & 14.01 & 14.38 & 768.98 & 1.58 & \\
\hline $6 / 02$ & HTK- & 9 & 1.1 & -02 & -03 & -03 & $2.65 \mathrm{E}-03$ & 1.70 & 1.25 & 11.4 & E-03 & E-02 & $5.59 \mathrm{E}-04$ & $\mathrm{E}-02$ & $2.42 \mathrm{E}-03$ & $3.11 \mathrm{E}-05$ & 15.49 & 14.5 & 16.36 & 1.64 & \\
\hline $6 / 02$ & HTK- & 56 & 0.83 & $1.49 \mathrm{E}-02$ & $5.00 \mathrm{E}-03$ & $2.85 \mathrm{E}-03$ & $2.65 \mathrm{E}-03$ & 1.20 & 0.92 & 7.8 & $9.10 \mathrm{E}-03$ & $1.59 \mathrm{E}-02$ & \begin{tabular}{|l|}
$5.59 \mathrm{E}-04$ \\
\end{tabular} & $6.10 \mathrm{E}-02$ & $1.89 \mathrm{E}-03$ & $3.11 \mathrm{E}-05$ & 10.79 & 13.3 & 577.89 & 1.45 & \\
\hline $6 / 02$ & $\overline{\Gamma V}$ & 4 & 0.97 & $1.49 \mathrm{E}-02$ & $5.00 \mathrm{E}-03$ & $35 \mathrm{E}-03$ & $2.65 \mathrm{E}-03$ & 1.14 & .85 & 7.34 & $\mathrm{E}-03$ & $9 \mathrm{E}-02$ & \begin{tabular}{|l|}
$5.59 \mathrm{E}-04$ \\
\end{tabular} & $\mathrm{E}-02$ & -03 & $3.11 \mathrm{E}-05$ & 10.33 & & 565.84 & 1.43 & \\
\hline \multicolumn{22}{|l|}{ Tank 32} \\
\hline $12 / 29 / 01$ & 200202525 & dip & 0.32 & $1.60 \mathrm{E}-03$ & $5.00 \mathrm{E}-03$ & $3.20 \mathrm{E}-03$ & $3.00 \mathrm{E}-03$ & 0.61 & 0.88 & 5.69 & 50E-03 & $6.22 \mathrm{E}-02$ & $0.00 \mathrm{E}+00$ & $1.43 \mathrm{E}-02$ & $4.00 \mathrm{E}-04$ & $1.87 \mathrm{E}-06$ & 7.65 & & 393.69 & 1.32 & 1.21 \\
\hline $09 / 17 / 01$ & 200181081 & dip & 0.32 & $1.02 \mathrm{E}-02$ & $5.00 \mathrm{E}-03$ & $2.90 \mathrm{E}-03$ & $8.60 \mathrm{E}-03$ & 2.12 & 2.90 & 5.69 & $1.00 \mathrm{E}-02$ & $1.74 \mathrm{E}-02$ & $0.00 \mathrm{E}+00$ & $5.40 \mathrm{E}-02$ & $1.00 \mathrm{E}-04$ & $1.62 \mathrm{E}-05$ & 11.07 & & 664.63 & 1.46 & 1.41 \\
\hline $09 / 01 / 01$ & 200181080 & dip & 0.32 & $1.50 \mathrm{E}-03$ & $5.00 \mathrm{E}-03$ & $3.00 \mathrm{E}-03$ & $2.80 \mathrm{E}-03$ & 1.32 & 2.08 & 3.975 & $2.80 \mathrm{E}-03$ & $2.70 \mathrm{E}-03$ & $0.00 \mathrm{E}+00$ & $4.90 \mathrm{E}-02$ & $1.00 \mathrm{E}-04$ & $7.31 \mathrm{E}-06$ & 7.68 & & 467.29 & 1.32 & 1.35 \\
\hline $08 / 16 / 01$ & 200173819 & dip & 0.21 & $1.40 \mathrm{E}-03$ & $5.00 \mathrm{E}-03$ & $2.80 \mathrm{E}-03$ & $2.60 \mathrm{E}-03$ & 0.71 & 1.17 & 2.26 & $2.60 \mathrm{E}-03$ & $6.20 \mathrm{E}-03$ & $0.00 \mathrm{E}+00$ & $2.30 \mathrm{E}-02$ & $1.00 \mathrm{E}-04$ & $6.47 \mathrm{E}-05$ & 4.37 & & 266.54 & 1.19 & 1.41 \\
\hline $05 / 15 / 01$ & 200156480 & dip & 0.13 & $6.70 \mathrm{E}-03$ & $5.00 \mathrm{E}-02$ & $3.20 \mathrm{E}-03$ & $6.10 \mathrm{E}-03$ & 1.04 & 2.02 & 3.83 & $6.80 \mathrm{E}-03$ & $2.62 \mathrm{E}-02$ & $0.00 \mathrm{E}+00$ & $3.90 \mathrm{E}-02$ & $1.90 \mathrm{E}-03$ & $1.56 \mathrm{E}-05$ & 7.17 & & 423.59 & 1.30 & 1.44 \\
\hline $6 / 02$ & HTK-505 & 196.5 & 1.1 & $1.49 \mathrm{E}-02$ & $5.00 \mathrm{E}-03$ & $2.85 \mathrm{E}-03$ & $2.65 \mathrm{E}-03$ & 1.70 & 1.20 & 6.3 & $9.10 \mathrm{E}-03$ & $1.59 \mathrm{E}-02$ & \begin{tabular}{|l|}
$5.59 \mathrm{E}-04$ \\
\end{tabular} & $6.10 \mathrm{E}-02$ & $1.42 \mathrm{E}-03$ & $3.11 \mathrm{E}-05$ & 10.33 & & 607.98 & 1.43 & \\
\hline $6 / 02$ & HTK-506 33 & 89 & 0.93 & $1.49 \mathrm{E}-02$ & $5.00 \mathrm{E}-03$ & $2.85 \mathrm{E}-03$ & $2.65 \mathrm{E}-03$ & 2.10 & 1.60 & 7.4 & $9.10 \mathrm{E}-03$ & $1.59 \mathrm{E}-02$ & $5.59 \mathrm{E}-04$ & $6.10 \mathrm{E}-02$ & $1.67 \mathrm{E}-03$ & $3.11 \mathrm{E}-05$ & 12.07 & 12.4 & 693.55 & 1.50 & \\
\hline $6 / 02$ & HTK-507 $7^{33}$ & 77 & 1 & $1.49 \mathrm{E}-02$ & $5.00 \mathrm{E}-03$ & $2.85 \mathrm{E}-03$ & $2.65 \mathrm{E}-03$ & 2.50 & 1.90 & 8.7 & 9.10E-03 & $1.59 \mathrm{E}-02$ & 5.59E-04 & $6.10 \mathrm{E}-02$ & $1.64 \mathrm{E}-03$ & $3.11 \mathrm{E}-05$ & 14.14 & 13.1 & 806.90 & 1.59 & \\
\hline
\end{tabular}


WSRC-TR-2002-00318, Rev. 0

Table IV. Available Tank 26, 46, 43 and 38 Analytic Data for Recent SRS Evaporator Operation

\begin{tabular}{|c|c|c|c|c|c|c|c|c|c|c|c|c|c|c|c|c|c|c|c|c|c|}
\hline Date & $\begin{array}{l}\text { Description/ } \\
\text { Reference }\end{array}$ & $\begin{array}{l}\text { Height } \\
\text { (inchs) }\end{array}$ & $\begin{array}{c}\text { Al } \\
(\mathbf{M})\end{array}$ & $\begin{array}{c}\mathrm{Cl} \\
(\mathrm{M})\end{array}$ & $\begin{array}{c}\mathrm{C}_{2} \mathrm{O}_{4} \\
(\mathrm{M})\end{array}$ & $\begin{array}{l}\mathrm{CO}_{3} \\
(\mathrm{M})\end{array}$ & $\begin{array}{c}\mathbf{F} \\
(\mathbf{M})\end{array}$ & $\begin{array}{l}\mathrm{NO}_{2} \\
(\mathrm{M})\end{array}$ & $\begin{array}{l}\mathrm{NO}_{3} \\
(\mathrm{M})\end{array}$ & $\begin{array}{l}\mathrm{OH} \\
(\mathrm{M})\end{array}$ & $\begin{array}{l}\mathrm{PO}_{4} \\
\text { (M) }\end{array}$ & $\begin{array}{l}\mathrm{SO}_{4} \\
(\mathrm{M})\end{array}$ & $\begin{array}{c}\mathbf{F e} \\
(\mathbf{M})\end{array}$ & $\begin{array}{c}\mathbf{K} \\
(\mathbf{M})\end{array}$ & $\begin{array}{c}\mathbf{S i} \\
(\mathbf{M})\end{array}$ & $\begin{array}{c}\mathbf{U} \\
(\mathbf{M})\end{array}$ & $\begin{array}{c}\text { Na } \\
\text { Calc } \\
(\mathrm{M})\end{array}$ & \begin{tabular}{|c|} 
Na \\
Meas \\
$(\mathrm{M})$ \\
\end{tabular} & $\begin{array}{c}\text { wt } \\
\text { salt, } \\
\text { g/L }\end{array}$ & $\begin{array}{c}\text { Densc } \\
\text { alc } \\
\text { g/ml }\end{array}$ & $\begin{array}{c}\text { Dens } \\
\text { meas } \\
\text { g/ml }\end{array}$ \\
\hline \multicolumn{22}{|c|}{ Tank 38} \\
\hline $12 / 26 / 01$ & 200200335 & dip & 0.06 & $5.90 \mathrm{E}-03$ & $1.90 \mathrm{E}-01$ & $3.10 \mathrm{E}-03$ & $2.90 \mathrm{E}-03$ & 1.48 & 2.32 & 5.46 & $1.13 \mathrm{E}-02$ & $4.29 \mathrm{E}-02$ & $0.00 \mathrm{E}+00$ & $2.20 \mathrm{E}-02$ & $3.30 \mathrm{E}-03$ & $1.51 \mathrm{E}-04$ & 9.81 & & 554.13 & 1.41 & 1.34 \\
\hline $09 / 27 / 01$ & 200180201 & dip & 0.005 & $1.40 \mathrm{E}-03$ & $1.90 \mathrm{E}-01$ & $2.90 \mathrm{E}-03$ & $2.70 \mathrm{E}-03$ & 0.42 & 0.78 & 1.82 & $2.70 \mathrm{E}-03$ & $1.13 \mathrm{E}-02$ & $0.00 \mathrm{E}+00$ & $6.50 \mathrm{E}-03$ & $1.50 \mathrm{E}-03$ & $6.01 \mathrm{E}-05$ & 3.44 & & 191.50 & 1.15 & 1.13 \\
\hline $07 / 08 / 01$ & 200165175 & dip & 0.01 & $2.90 \mathrm{E}-03$ & $1.00 \mathrm{E}-02$ & $5.90 \mathrm{E}-03$ & $5.50 \mathrm{E}-03$ & 0.34 & 0.36 & 1.71 & $5.50 \mathrm{E}-03$ & $8.60 \mathrm{E}-03$ & $0.00 \mathrm{E}+00$ & $1.33 \mathrm{E}-02$ & $1.40 \mathrm{E}-03$ & $3.90 \mathrm{E}-05$ & 2.48 & & 128.42 & 1.11 & 1.06 \\
\hline $05 / 16 / 01$ & 200156413 & dip & 0.16 & $3.30 \mathrm{E}-03$ & $.00 \mathrm{E}-02$ & $9.00 \mathrm{E}-03$ & $2.50 \mathrm{E}-03$ & 0.46 & 0.51 & 1.71 & $2.50 \mathrm{E}-03$ & $2.18 \mathrm{E}-02$ & $0.00 \mathrm{E}+00$ & $1.22 \mathrm{E}-02$ & $4.50 \mathrm{E}-03$ & $2.20 \mathrm{E}-04$ & 3.01 & & 173.17 & 1.13 & 1.17 \\
\hline \multicolumn{22}{|c|}{ Tank 43} \\
\hline $12 / 27 / 01$ & 200200601 & dip & 0.1 & $1.60 \mathrm{E}-03$ & $8.00 \mathrm{E}-02$ & $3.20 \mathrm{E}-03$ & $3.00 \mathrm{E}-03$ & 0.83 & 1.33 & 2.82 & $3.00 \mathrm{E}-03$ & $2.09 \mathrm{E}-02$ & $0.00 \mathrm{E}+00$ & $7.10 \mathrm{E}-03$ & $3.40 \mathrm{E}-03$ & $1.22 \mathrm{E}-04$ & 5.30 & & 308.35 & 1.23 & 1.22 \\
\hline $11 / 01 / 01$ & 200188563 & dip & 0.09 & $3.90 \mathrm{E}-03$ & $8.00 \mathrm{E}-02$ & $3.00 \mathrm{E}-03$ & $2.80 \mathrm{E}-03$ & 0.81 & 1.31 & 3.02 & $6.10 \mathrm{E}-03$ & $1.99 \mathrm{E}-02$ & $0.00 \mathrm{E}+00$ & $1.40 \mathrm{E}-02$ & $1.20 \mathrm{E}-03$ & $1.61 \mathrm{E}-04$ & 5.44 & & 311.75 & 1.23 & 1.23 \\
\hline $10 / 08 / 01$ & 200183245 & dip & 0.19 & $4.30 \mathrm{E}-03$ & $1.20 \mathrm{E}-01$ & $3.20 \mathrm{E}-03$ & $3.00 \mathrm{E}-03$ & 0.84 & 1.38 & 2.83 & $6.50 \mathrm{E}-03$ & $2.24 \mathrm{E}-02$ & $0.00 \mathrm{E}+00$ & $1.60 \mathrm{E}-02$ & $2.50 \mathrm{E}-03$ & $1.99 \mathrm{E}-04$ & 5.55 & & 329.73 & 1.24 & 1.22 \\
\hline $09 / 27 / 01$ & 200180202 & dip & 0.005 & $3.60 \mathrm{E}-03$ & $1.00 \mathrm{E}-01$ & $3.00 \mathrm{E}-03$ & $2.70 \mathrm{E}-03$ & 0.85 & 1.44 & 3.65 & $6.70 \mathrm{E}-03$ & $2.27 \mathrm{E}-02$ & $0.00 \mathrm{E}+00$ & $6.64 \mathrm{E}-03$ & $2.50 \mathrm{E}-03$ & $1.84 \mathrm{E}-05$ & 6.23 & & 344.16 & 1.27 & 1.24 \\
\hline $07 / 04 / 01$ & No ID & dip & 0.14 & $6.80 \mathrm{E}-03$ & $1.00 \mathrm{E}-02$ & $6.40 \mathrm{E}-03$ & $5.90 \mathrm{E}-03$ & 0.93 & 1.33 & 2.65 & $6.20 \mathrm{E}-03$ & $2.26 \mathrm{E}-02$ & $0.00 \mathrm{E}+00$ & $1.44 \mathrm{E}-02$ & $4.00 \mathrm{E}-04$ & $5.76 \mathrm{E}-05$ & 5.14 & & 306.74 & 1.22 & 1.23 \\
\hline $05 / 16 / 01$ & 20015614 & dip & 0.5 & $5.70 \mathrm{E}-03$ & $5.00 \mathrm{E}-03$ & $2.90 \mathrm{E}-03$ & $2.70 \mathrm{E}-03$ & 0.83 & 1.23 & 3.01 & $6.90 \mathrm{E}-03$ & $2.24 \mathrm{E}-02$ & $0.00 \mathrm{E}+00$ & $1.05 \mathrm{E}-02$ & $6.70 \mathrm{E}-03$ & $8.40 \mathrm{E}-05$ & 5.67 & & 348.32 & 1.24 & 1.27 \\
\hline $03 / 08 / 01$ & 200142705 & dip & 0.08 & $7.40 \mathrm{E}-03$ & $5.00 \mathrm{E}-03$ & $3.00 \mathrm{E}-03$ & $2.70 \mathrm{E}-03$ & 0.84 & 1.20 & 2.56 & $2.70 \mathrm{E}-03$ & $1.84 \mathrm{E}-02$ & $0.00 \mathrm{E}+00$ & $6.50 \mathrm{E}-03$ & $3.60 \mathrm{E}-03$ & $5.04 \mathrm{E}-05$ & 4.76 & & 277.46 & 1.21 & 1.20 \\
\hline \multicolumn{22}{|c|}{ Tank 46 } \\
\hline $11 / 01 / 01$ & 200188683 & dip & 0.06 & $2.50 \mathrm{E}-02$ & $1.30 \mathrm{E}-01$ & $3.00 \mathrm{E}-03$ & $7.70 \mathrm{E}-03$ & 1.95 & 1.68 & 9.72 & $1.34 \mathrm{E}-02$ & $6.70 \mathrm{E}-03$ & $0.00 \mathrm{E}+00$ & $8.60 \mathrm{E}-02$ & $1.70 \mathrm{E}-03$ & $4.11 \mathrm{E}-05$ & 13.68 & & 693.80 & 1.57 & 1.46 \\
\hline $08 / 15 / 01$ & 200171513 & dip & 0.1 & $2.90 \mathrm{E}-03$ & $5.00 \mathrm{E}-02$ & $6.90 \mathrm{E}-03$ & $6.90 \mathrm{E}-03$ & 0.53 & 1.09 & 2 & $5.40 \mathrm{E}-03$ & $5.97 \mathrm{E}-02$ & $0.00 \mathrm{E}+00$ & $1.60 \mathrm{E}-02$ & $4.00 \mathrm{E}-04$ & $4.54 \mathrm{E}-05$ & 3.96 & & 237.35 & 1.17 & 1.15 \\
\hline $05 / 23 / 01$ & 200157905 & dip & 0.07 & $3.59 \mathrm{E}-02$ & $5.00 \mathrm{E}-03$ & $2.80 \mathrm{E}-03$ & $7.80 \mathrm{E}-03$ & 2.48 & 2.03 & 1.23 & $1.76 \mathrm{E}-02$ & 7.00E-03 & $0.00 \mathrm{E}+00$ & $1.07 \mathrm{E}-01$ & $3.40 \mathrm{E}-03$ & $2.96 \mathrm{E}-05$ & 5.84 & & 410.59 & 1.25 & 1.55 \\
\hline \multicolumn{22}{|c|}{ Tank 26} \\
\hline $11 / 01 / 01$ & 200188682 & dip & 0.37 & $2.10 \mathrm{E}-02$ & $1.40 \mathrm{E}-01$ & $3.00 \mathrm{E}-03$ & $2.80 \mathrm{E}-03$ & 1.59 & 1.94 & 8.12 & $1.16 \mathrm{E}-02$ & $1.30 \mathrm{E}-02$ & $0.00 \mathrm{E}+00$ & $7.50 \mathrm{E}-02$ & $1.10 \mathrm{E}-03$ & 2.39E-05 & 12.32 & & 664.85 & 1.51 & 1.42 \\
\hline $08 / 15 / 01$ & 200171514 & dip & 0.95 & $2.49 \mathrm{E}-02$ & $5.00 \mathrm{E}-03$ & $2.90 \mathrm{E}-03$ & $6.20 \mathrm{E}-03$ & 2.03 & 1.56 & 9 & $1.31 \mathrm{E}-02$ & $1.08 \mathrm{E}-02$ & $0.00 \mathrm{E}+00$ & $8.30 \mathrm{E}-02$ & $7.00 \mathrm{E}-04$ & $4.75 \mathrm{E}-05$ & 13.57 & & 752.92 & 1.56 & 1.46 \\
\hline $05 / 27 / 01$ & 200158849 & dip & 0.31 & $2.35 \mathrm{E}-02$ & $5.00 \mathrm{E}-03$ & $3.30 \mathrm{E}-03$ & $3.10 \mathrm{E}-03$ & 1.88 & 2.00 & 8.12 & $1.20 \mathrm{E}-02$ & $1.90 \mathrm{E}-02$ & $0.00 \mathrm{E}+00$ & $8.10 \mathrm{E}-02$ & $3.00 \mathrm{E}-03$ & $2.16 \mathrm{E}-06$ & 12.35 & & 669.83 & 1.51 & 1.47 \\
\hline
\end{tabular}


WSRC-TR-2002-00318, Rev. 0

Table V. Tank 30 and 32 Modeling Data for Recent SRS Evaporator Operation

\begin{tabular}{|c|c|c|c|c|c|c|c|c|c|c|c|c|c|c|c|c|c|}
\hline Date & $\begin{array}{l}\text { Description/ } \\
\text { Reference }\end{array}$ & $\begin{array}{l}\text { Height } \\
\text { (inchs) }\end{array}$ & $\begin{array}{c}\text { Al } \\
(\mathbf{m})\end{array}$ & $\begin{array}{l}\mathrm{Cl} \\
(\mathrm{m})\end{array}$ & $\begin{array}{c}\mathrm{CO}_{3}+ \\
\mathrm{C}_{2} \mathrm{O}_{4} \\
(\mathrm{~m})\end{array}$ & $\begin{array}{c}\mathbf{F} \\
(\mathbf{m})\end{array}$ & $\begin{array}{l}\mathrm{NO}_{2} \\
(\mathrm{~m})\end{array}$ & $\begin{array}{l}\mathrm{NO}_{3} \\
(\mathrm{~m})\end{array}$ & $\begin{array}{l}\text { OH } \\
(\mathbf{m})\end{array}$ & $\begin{array}{l}\mathrm{PO}_{4} \\
(\mathrm{~m})\end{array}$ & $\begin{array}{l}\mathrm{SO}_{4} \\
(\mathrm{~m})\end{array}$ & $\begin{array}{l}\mathrm{Fe} \\
(\mathbf{m})\end{array}$ & $\begin{array}{l}\mathbf{K} \\
(\mathbf{m})\end{array}$ & $\begin{array}{c}\mathbf{S i} \\
(\mathrm{m})\end{array}$ & $\begin{array}{l}\mathbf{U} \\
(\mathbf{m})\end{array}$ & $\begin{array}{c}\text { Na } \\
\text { Calc } \\
(\mathrm{m}) \\
\end{array}$ & $\begin{array}{c}\mathrm{NO}_{2}+ \\
\mathrm{NO}_{3} \\
(\mathrm{~m}) \\
\end{array}$ \\
\hline \multicolumn{18}{|l|}{ Tank 30} \\
\hline $10 / 21 / 01$ & 200186142 & dip & 04E-01 & $1.50 \mathrm{E}-03$ & $2.19 \mathrm{E}-02$ & $6.36 \mathrm{E}-03$ & $5.29 \mathrm{E}-01$ & $7.27 \mathrm{E}-01$ & $1.27 \mathrm{E}+00$ & $2.82 \mathrm{E}-03$ & $2.02 \mathrm{E}-02$ & $0.00 \mathrm{E}+00$ & $3.13 \mathrm{E}-03$ & $1.56 \mathrm{E}-03$ & $8.37 \mathrm{E}-07$ & $2.72 \mathrm{E}+00$ & $1.26 \mathrm{E}+00$ \\
\hline $08 / 16 / 01$ & 200173820 & dip & $4.91 \mathrm{E}-01$ & $9.06 \mathrm{E}-03$ & $1.34 \mathrm{E}-02$ & $1.14 \mathrm{E}-02$ & $3.74 \mathrm{E}+00$ & $2.98 \mathrm{E}+00$ & $7.15 \mathrm{E}+00$ & $5.16 \mathrm{E}-03$ & $4.80 \mathrm{E}-03$ & $0.00 \mathrm{E}+00$ & $1.53 \mathrm{E}-03$ & $1.01 \mathrm{E}-03$ & $1.20 \mathrm{E}-05$ & $1.44 \mathrm{E}+01$ & $6.73 \mathrm{E}+00$ \\
\hline $05 / 30 / 01$ & 200154415 & dip & $4.60 \mathrm{E}-01$ & $1.69 \mathrm{E}-03$ & $1.25 \mathrm{E}-02$ & $1.41 \mathrm{E}-02$ & $1.68 \mathrm{E}+00$ & $2.38 \mathrm{E}+00$ & $3.20 \mathrm{E}+00$ & $6.48 \mathrm{E}-03$ & $5.66 \mathrm{E}-02$ & $0.00 \mathrm{E}+00$ & $4.01 \mathrm{E}-02$ & $2.95 \mathrm{E}-03$ & $2.15 \mathrm{E}-05$ & $7.85 \mathrm{E}+00$ & $4.06 \mathrm{E}+00$ \\
\hline $1 / 02$ & HTK- $481^{32}$ & VDS & $6.98 \mathrm{E}-01$ & $1.73 \mathrm{E}-02$ & $1.25 \mathrm{E}-02$ & $3.08 \mathrm{E}-03$ & $2.05 \mathrm{E}+00$ & $1.47 \mathrm{E}+00$ & $1.10 \mathrm{E}+01$ & $1.06 \mathrm{E}-02$ & $1.85 \mathrm{E}-02$ & $6.50 \mathrm{E}-04$ & $7.10 \mathrm{E}-02$ & $3.31 \mathrm{E}-03$ & $3.62 \mathrm{E}-05$ & $1.52 \mathrm{E}+01$ & $3.51 \mathrm{E}+00$ \\
\hline $1 / 02$ & HTK-482 32 & VDS & $1.36 \mathrm{E}+00$ & $1.84 \mathrm{E}-02$ & $1.32 \mathrm{E}-02$ & $3.27 \mathrm{E}-03$ & $2.37 \mathrm{E}+00$ & $1.69 \mathrm{E}+00$ & $1.18 \mathrm{E}+01$ & $1.12 \mathrm{E}-02$ & $1.96 \mathrm{E}-02$ & $6.89 \mathrm{E}-04$ & $7.52 \mathrm{E}-02$ & $3.29 \mathrm{E}-03$ & $3.83 \mathrm{E}-05$ & $1.73 \mathrm{E}+01$ & $4.06 \mathrm{E}+00$ \\
\hline $6 / 02$ & HTK-508 ${ }^{33}$ & 221.9 & $1.34 \mathrm{E}+00$ & 02 & $1.30 \mathrm{E}-02$ & $3.22 \mathrm{E}-03$ & $2.06 \mathrm{E}+00$ & $1.52 \mathrm{E}+00$ & $1.38 \mathrm{E}+01$ & $1.10 \mathrm{E}-02$ & $1.93 \mathrm{E}-02$ & -04 & $7.41 \mathrm{E}-02$ & $2.94 \mathrm{E}-03$ & $8-05$ & $1.88 \mathrm{E}+01$ & $3.58 \mathrm{E}+00$ \\
\hline $6 / 02$ & HTK-509 33 & 156 & $9.52 \mathrm{E}-01$ & $1.71 \mathrm{E}-02$ & $1.23 \mathrm{E}-02$ & $3.04 \mathrm{E}-03$ & $1.38 \mathrm{E}+00$ & $1.06 \mathrm{E}+00$ & $8.95 \mathrm{E}+00$ & $1.04 \mathrm{E}-02$ & $1.82 \mathrm{E}-02$ & $6.41 \mathrm{E}-04$ & $7.00 \mathrm{E}-02$ & $2.16 \mathrm{E}-03$ & $3.57 \mathrm{E}-05$ & $1.24 \mathrm{E}+01$ & $2.43 \mathrm{E}+00$ \\
\hline $6 / 02$ & HTK 5 & 4 & $1.12 \mathrm{E}+00$ & $1.72 \mathrm{E}-02$ & $1.24 \mathrm{E}-02$ & $3.06 \mathrm{E}-03$ & $1.32 \mathrm{E}+00$ & $9.82 \mathrm{E}-01$ & $8.48 \mathrm{E}+00$ & $1.05 \mathrm{E}-02$ & $1.84 \mathrm{E}-02$ & $6.45 \mathrm{E}-04$ & $7.05 \mathrm{E}-02$ & $1.48 \mathrm{E}-03$ & $3.59 \mathrm{E}-05$ & $1.19 \mathrm{E}+01$ & $2.30 \mathrm{E}+00$ \\
\hline \multicolumn{18}{|l|}{ Tank 32} \\
\hline $12 / 29 / 01$ & 200202525 & dip & $3.44 \mathrm{E}-01$ & $1.72 \mathrm{E}-03$ & $1.23 \mathrm{E}-02$ & $3.23 \mathrm{E}-03$ & $6.58 \mathrm{E}-01$ & $9.47 \mathrm{E}-01$ & $6.12 \mathrm{E}+00$ & $6.99 \mathrm{E}-03$ & $6.69 \mathrm{E}-02$ & $0.00 \mathrm{E}+00$ & $1.54 \mathrm{E}-02$ & $4.30 \mathrm{E}-04$ & $2.01 \mathrm{E}-06$ & $8.23 \mathrm{E}+00$ & $1.60 \mathrm{E}+00$ \\
\hline $08 / 16 / 01$ & 200173819 & dip & $2.27 \mathrm{E}-01$ & $1.52 \mathrm{E}-03$ & $1.15 \mathrm{E}-02$ & $2.82 \mathrm{E}-03$ & $7.72 \mathrm{E}-01$ & $1.27 \mathrm{E}+00$ & $2.45 \mathrm{E}+00$ & $2.82 \mathrm{E}-03$ & $6.71 \mathrm{E}-03$ & $0.00 \mathrm{E}+00$ & $2.49 \mathrm{E}-02$ & $1.08 \mathrm{E}-04$ & $7.01 \mathrm{E}-05$ & $4.73 \mathrm{E}+00$ & $2.04 \mathrm{E}+00$ \\
\hline $05 / 15 / 01$ & 200156480 & dip & $1.48 \mathrm{E}-01$ & $7.61 \mathrm{E}-03$ & $6.41 \mathrm{E}-02$ & \begin{tabular}{l|l}
$6.93 \mathrm{E}-03$ & 1
\end{tabular} & $1.18 \mathrm{E}+00$ & $2.29 \mathrm{E}+00$ & $4.35 \mathrm{E}+00$ & $7.73 \mathrm{E}-03$ & $2.98 \mathrm{E}-02$ & $0.00 \mathrm{E}+00$ & $4.43 \mathrm{E}-02$ & $2.16 \mathrm{E}-03$ & $1.77 \mathrm{E}-05$ & $8.15 \mathrm{E}+00$ & $3.47 \mathrm{E}+00$ \\
\hline $6 / 02$ & HTK-505 $5^{33}$ & 196.5 & $1.34 \mathrm{E}+00$ & $1.81 \mathrm{E}-02$ & $1.30 \mathrm{E}-02$ & \begin{tabular}{l|l}
$3.22 \mathrm{E}-03$ & 2 \\
\end{tabular} & $2.06 \mathrm{E}+00$ & $1.46 \mathrm{E}+00$ & $7.65 \mathrm{E}+00$ & $1.10 \mathrm{E}-02$ & $1.93 \mathrm{E}-02$ & $6.78 \mathrm{E}-04$ & $7.41 \mathrm{E}-02$ & $1.73 \mathrm{E}-03$ & $3.78 \mathrm{E}-05$ & $1.25 \mathrm{E}+01$ & $3.52 \mathrm{E}+00$ \\
\hline $6 / 02$ & HTK-506 $6^{33}$ & 89 & $1.15 \mathrm{E}+00$ & $1.84 \mathrm{E}-02$ & $1.32 \mathrm{E}-02$ & $3.28 \mathrm{E}-03$ & $2.60 \mathrm{E}+00$ & $1.98 \mathrm{E}+00$ & $9.16 \mathrm{E}+00$ & $1.13 \mathrm{E}-02$ & $1.97 \mathrm{E}-02$ & $6.91 \mathrm{E}-04$ & $7.55 \mathrm{E}-02$ & $2.07 \mathrm{E}-03$ & $3.85 \mathrm{E}-05$ & $1.49 \mathrm{E}+01$ & $4.58 \mathrm{E}+00$ \\
\hline $6 / 02$ & HTK-507 & 77 & $1.28 \mathrm{E}+00$ & $1.91 \mathrm{E}-02$ & $1.37 \mathrm{E}-02$ & $3.40 \mathrm{E}-03$ & $3.21 \mathrm{E}+00$ & $2.44 \mathrm{E}+00$ & $1.12 \mathrm{E}+01$ & $1.17 \mathrm{E}-02$ & $2.04 \mathrm{E}-02$ & $7.18 \mathrm{E}-04$ & $7.84 \mathrm{E}-02$ & $2.10 \mathrm{E}-03$ & $3.99 \mathrm{E}-05$ & $1.82 \mathrm{E}+01$ & $5.65 \mathrm{E}+00$ \\
\hline
\end{tabular}
$\mathrm{m}=$ molal $\left(\mathrm{mole} / \mathrm{Kg} \mathrm{H}_{2} \mathrm{O}\right)$ 
WSRC-TR-2002-00318, Rev. 0

Table VI. Tank 26, 46, 43 and 38 Modeling Data for Recent SRS Evaporator Operation

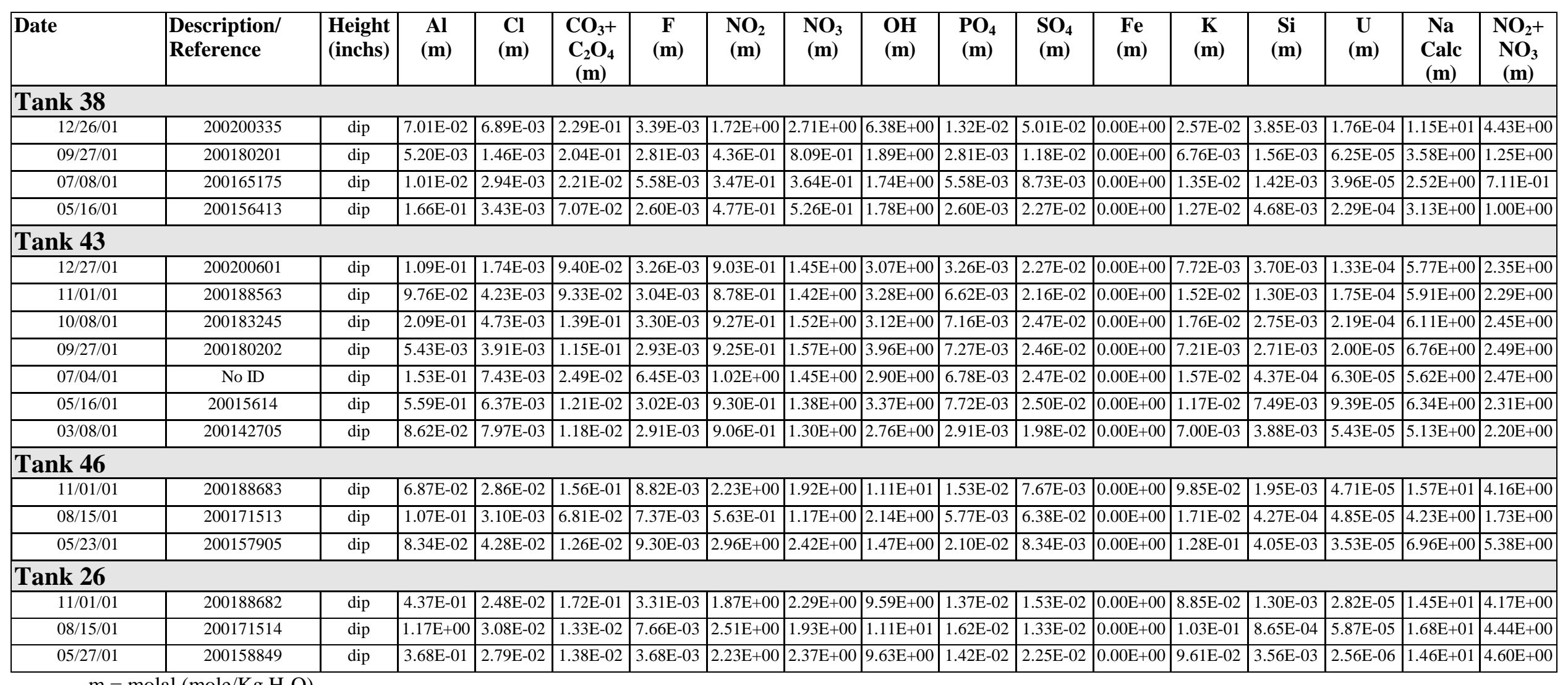

$\mathrm{m}=$ molal $\left(\mathrm{mole} / \mathrm{Kg} \mathrm{H}_{2} \mathrm{O}\right)$ 


\subsection{MODELING APPROACH}

The molar tank compositions given in Table III and Table IV were converted into molal units which are the units of preference in the GWB software. The conversion formula takes the form ${ }^{5}$

$$
\left[\mathrm{i}^{+/-}\right]_{\mathrm{m}}=\frac{\left[\mathrm{i}^{+/-}\right]_{\mathrm{M}}}{\rho-\sum \rho_{\text {solutes }}}
$$

where $\left[\mathrm{i}^{+/-}\right]_{\mathrm{M}}$ and $\left[\mathrm{i}^{+/-}\right]_{\mathrm{m}}$ are the molar and molal concentrations of ionic species $\mathrm{i}$, respectively, $\rho$ is the solution density in $\mathrm{kg} / \mathrm{L}$, and $\Sigma \rho_{\text {solutes }}$ is the sum of the partial densities of the dissolved solids. The solution density is calculated using Equation 11b. For each ionic species, the partial dissolved solids density is the product of its molarity and its ionic weight in $\mathrm{g} / \mathrm{mole}$. Ionic weights for the most prevalent species in basic solutions are used. These are $\mathrm{Al}(\mathrm{OH})_{4}{ }^{-}, \mathrm{Cl}^{-}, \mathrm{CO}_{3}{ }^{2-}, \mathrm{F}^{-}, \mathrm{NO}_{2}^{-}, \mathrm{NO}_{3}{ }^{-}, \mathrm{OH}^{-}, \mathrm{PO}_{4}{ }^{3-}, \mathrm{SO}_{4}{ }^{2-}$, $\mathrm{Fe}(\mathrm{OH})_{4}^{-}, \mathrm{K}^{+}, \mathrm{H}_{2} \mathrm{SiO}_{4}{ }^{2-},\left(\mathrm{UO}_{2}\right)_{3}(\mathrm{OH})_{7}^{-}$, and $\mathrm{Na}^{+}$. Table $\mathrm{V}$ and Table VI reflects the input data in molalities used for modeling.

There is limited solubility data for amorphous $\mathrm{SiO}_{2}$ and $\mathrm{Al}(\mathrm{OH})_{3}$ in very basic high ionic strength solutions such as those in the SRS 3H Evaporator. This is discussed in more detail in Part $\mathrm{I}^{3}$ Comparison with available $\mathrm{SiO}_{2}$ solubility data in the literature showed that the solubility data used in GWB appeared to adequately represent amorphous $\mathrm{SiO}_{2}$ equilibria in basic $\mathrm{pH}$. GWB has the mononuclear silicate species $\mathrm{H}_{4} \mathrm{SiO}_{4}$ called $\mathrm{SiO}_{2}(\mathrm{aq})$, $\mathrm{H}_{3} \mathrm{SiO}_{4}^{-}$and $\mathrm{H}_{2} \mathrm{SiO}_{4}^{2-}$ of which the $\mathrm{H}_{2} \mathrm{SiO}_{4}^{2-}$ species is the most prevalent at $\mathrm{pH}$ values $>13$. $^{36}$ GWB also contains the two most abundant ${ }^{37,36}$ polynuclear silicate species, the tetrameric $\mathrm{H}_{4}\left(\mathrm{H}_{2} \mathrm{SiO}_{4}\right)_{4}^{4-}$ and $\mathrm{H}_{6}\left(\mathrm{H}_{2} \mathrm{SiO}_{4}\right)_{4}^{2-}$ of which the tetrameric $\mathrm{H}_{4}\left(\mathrm{H}_{2} \mathrm{SiO}_{4}\right)_{4}^{4-}$ is the most prevalent species at $\mathrm{pH}$ values $>13 .{ }^{36}$ Polynuclear $\mathrm{Si}(\mathrm{IV})$ species are only significant at $\mathrm{pH}>10$ and a total dissolved Si concentrations larger than $10^{-3} \mathrm{M}^{38}$ In addition, the significance of the polynuclear $\mathrm{Si}(\mathrm{IV})$ species tends to decrease with increasing temperature. $^{39}$ Since the SRS Evaporator Si concentrations are in the

$10^{-4} \mathrm{M}$ concentration range (Table III and Table IV) and the polynuclear Si(IV) species are of minimal importance at the elevated evaporator operating temperatures, the absence of the remaining polynuclear $\mathrm{Si}(\mathrm{IV})$ species in the GWB database is not considered to significantly impact the modeling.

Examination of the gibbsite solubility data in GWB with that in the literature indicated that Russell's ${ }^{40}$ solubility data at a sodium molality of 8.5 would be more appropriate for modeling at the high ionic strength of the SRS Evaporators. The Russel solubility data for gibbsite (alpha aluminum trihydrate) and diaspore (alpha aluminum monohydrate) was added to GWB database and designated as "gibbsite-M" and "diaspore-M" to distinguish these modified aluminum hydroxides from the gibbsite and diaspore solubility already in GWB. The Russel gibbsite-M and diaspore-M were used for modeling the SRS 3H Evaporator solutions. The data for the solubility of $\mathrm{NaAlO}_{2}$ and $\mathrm{AlO}_{2}^{-2}$ of Reynolds and Herting ${ }^{41}$ were also added to GWB for completeness. Detailed descriptions of the manner in which the data were added to the GWB database appear in Part I. ${ }^{3}$ 
The data of $\mathrm{Ejaz}^{20}$ for the solubility of the NAS gel and Zeolite-A was added to the GWB database as was the data of Gasteiger ${ }^{23}$ for an amorphous precipitate containing Zeolite-A and nitrited sodalite, hereafter referred to as "mixed zeolite." The manner in which the aluminosilicate data was added to the GWB is discussed in greater detail in Part $\mathrm{I}^{3}$

\subsection{BOUNDING TEMPERATURES}

The nominal evaporator process model was generated using a pooled temperature data set where some of the $\log (\mathrm{Q} / \mathrm{K})_{\mathrm{NAS}}$ values had been calculated at $120^{\circ} \mathrm{C}$ and some had been calculated at $140^{\circ} \mathrm{C}$. The $\log (\mathrm{Q} / \mathrm{K})_{\mathrm{NAS}}$ saturation values had been calculated at $120^{\circ} \mathrm{C}$ for the SRS $2 \mathrm{H}$ and $2 \mathrm{~F}$ Evaporators since these evaporators ran at $\sim 120^{\circ} \mathrm{C}^{f}$ during the time period modeled in Part $\mathrm{I}^{3}$ of this study. The $\log (\mathrm{Q} / \mathrm{K})_{\mathrm{NAS}}$ saturation values had been calculated at $140^{\circ} \mathrm{C}$ for the SRS $3 \mathrm{H}$ Evaporator since it ran between $135-140^{\circ} \mathrm{C}$ (data from Kent Gilbreath March 2001) during the time period modeled in Part $\mathrm{I}^{3}$ of this study. The pooled data set was used for the following reasons:

- The pooled data spanned the actual operating temperatures of the evaporations that had been performed

- Figure B-13 in Part $\mathrm{I}^{3}$ demonstrated that the solubility of the NAS $\mathrm{Sel}_{\text {gel }}$ as taken from the literature is a linear function of $1 / \mathrm{T}(\mathrm{K})$ for the data examined. The $\log \left([\mathrm{Al}]^{*}[\mathrm{Si}]\right)$ at $120^{\circ} \mathrm{C}$ and at $140^{\circ} \mathrm{C}$ was calculated from the equation given in Figure B-13 indicating that there is little predicted change in the NAS $\mathrm{gel}_{\mathrm{g}}$ solubility at elevated temperature.

Currently, the $3 \mathrm{H}$ Evaporator is running at temperatures as high as $\sim 180^{\circ} \mathrm{C}$. Therefore, the applicability of the model over the range of operating conditions for all SRS evaporators, e.g., from $120^{\circ} \mathrm{C}$ to $180^{\circ} \mathrm{C}$, was investigated to further evaluate the dependency of the $\log (\mathrm{Q} / \mathrm{K})_{\mathrm{NAS}}$ saturation values in Figure 4 to temperature.

In order to evaluate the solution equilibria at elevated temperatures, the solution temperature was incrementally increased, using the polythermal reaction option in GWB. These calculations simulated evaporation by a stepwise removal of $40 \mathrm{wt} \%$ of the water from the solution. This amount of evaporation changes the solution density from about $1.4 \mathrm{~g} / \mathrm{cm}^{3}$ to about $1.6 \mathrm{~g} / \mathrm{cm}^{3}$, the latter number being the operational target density for the SRS Evaporators.

Between 1996 and 1999 when the $2 \mathrm{H}$ evaporator was shut down, it ran at a nominal temperature of $120-125^{\circ} \mathrm{C}$ but ranged from a low of $99^{\circ} \mathrm{C}(12 / 06 / 97$ morning report $)$ to a high of $139^{\circ} \mathrm{C}(5 / 16 / 98$ morning report). 


\subsection{Upper and Lower Temperature Bounds}

The upper and lower temperature bounds were evaluated by fitting OLS models to the entire tank data set from Part $\mathrm{I}^{3}$ (101 data points representing all the evaporator systems) shown in Figure 4 at $120^{\circ} \mathrm{C}, 140^{\circ} \mathrm{C}, 165$, and $180^{\circ} \mathrm{C}$. A comparison was then made of the upper and lower temperature bounds to the nominal evaporator process model developed with the pooled $120^{\circ} \mathrm{C} / 140^{\circ} \mathrm{C}$ data set (Equation 10). The relation of the upper temperature bound to the lower temperature bound was also evaluated. Usage of the model at temperatures above $180^{\circ} \mathrm{C}$ is complicated by an increasingly large field of crystalline $\mathrm{NaAlO}_{2}$ which intersects the field of $\mathrm{NAS}_{\text {gel }}$ on the stability diagrams so that Equation 10 no longer applies. In other words, the pertinent equilibrium above $180^{\circ} \mathrm{C}$ is an equilibrium between $\mathrm{NaAlO}_{2}$ and $\mathrm{NAS}_{\text {gel }}$ and not $\mathrm{AlOOH}$ and $\mathrm{NAS}_{\mathrm{gel}}$ as defined by Equation 10.

$\log (\mathrm{Q} / \mathrm{K})_{\mathrm{NAS}}$ values were calculated at $120^{\circ} \mathrm{C}$ for the 101 tank compositions, which represents the lower bounding temperature at $40 \mathrm{wt} \%$ evaporation (Equation 13). Similarly, the $\log (\mathrm{Q} / \mathrm{K})_{\mathrm{NAS}}$ values were computed for all tank compositions at $180^{\circ} \mathrm{C}$ and $40 \mathrm{wt} \%$ evaporation to provide an upper bound for evaporator operations (Equation 14). Calculations at $140^{\circ} \mathrm{C}$ and $165^{\circ} \mathrm{C}$ and $40 \mathrm{wt} \%$ evaporation are provided as intermediate cases (Equations 15 and 16).

$$
\begin{aligned}
& \log \mathrm{Q} / \mathrm{K}_{\left(\mathrm{NAS} @ 120^{\circ} \mathrm{C}\right)}=36.85+0.98 \log \mathrm{Q}(\mathrm{NAS})_{25^{\circ} \mathrm{C}} ; \mathrm{R}^{2}=0.92 \\
& \log \mathrm{Q} / \mathrm{K}_{\left(\mathrm{NAS} @ 180^{\circ} \mathrm{C}\right)}=37.57+0.97 \log \mathrm{Q}(\mathrm{NAS})_{25^{\circ} \mathrm{C}} ; \mathrm{R}^{2}=0.91 \\
& \log \mathrm{Q} / \mathrm{K}_{\left(\mathrm{NAS} @ 165^{\circ} \mathrm{C}\right)}=38.04+0.98 \log \mathrm{Q}(\mathrm{NAS})_{25^{\circ} \mathrm{C}} ; \mathrm{R}^{2}=0.91 \\
& \log \mathrm{Q} / \mathrm{K}_{\left(\mathrm{NAS} @ 140^{\circ} \mathrm{C}\right)}=37.77+0.98 \log \mathrm{Q}(\mathrm{NAS})_{25^{\circ} \mathrm{C}} ; \mathrm{R}^{2}=0.92
\end{aligned}
$$

Comparison of Equations 10 and 13 indicated that the response of Equation 10 is dominated by the $78 \log (\mathrm{Q} / \mathrm{K})_{\text {NAS }}$ values calculated at $120^{\circ} \mathrm{C}$ rather than the 23 $\log (\mathrm{Q} / \mathrm{K})_{\text {NAS }}$ values calculated at $140^{\circ} \mathrm{C}$, e.g. the slopes differ by 0.013 and the intercepts by 0.4066 . Comparison of Equations 13 and 14 indicates that the slopes of the low temperature $\left(120^{\circ} \mathrm{C}\right)$ saturation correlation and the high temperature $\left(180^{\circ} \mathrm{C}\right)$ saturation correlation differ by 0.0101 . The main difference in the prediction of saturation at the lower temperature $\left(120^{\circ} \mathrm{C}\right)$ and upper temperature $\left(180^{\circ} \mathrm{C}\right)$ bound is expressed in the intercept term which has a difference of 0.7145 larger in Equation 14. Note that the use of the pooled temperature data set in Equation 10 yields a correlation with slightly more bias (a lower $\mathrm{R}^{2}$ of 0.90 ) than the saturation correlations at a single temperature (Equations 13-16 with $\mathrm{R}^{2}$ values of 0.91 and 0.92 ). 
WSRC-TR-2002-00318, Rev. 0

The $140^{\circ} \mathrm{C}, 165^{\circ} \mathrm{C}$, and $180^{\circ} \mathrm{C}$ data fall within the conservative $95 \%$ bias bands (analogous to the error bands) shown in Figure 5 (black dashed lines). Figure 5 also shows that the regression fit for the $165^{\circ} \mathrm{C}$ (red OLS fit) and $180^{\circ} \mathrm{C}$ (green OLS fit) data is almost coincident with the regression fit for the pooled $120^{\circ} \mathrm{C} / 140^{\circ} \mathrm{C}$ data (black OLS fit).

\subsection{Operational Process Control Limit Temperature Effects}

In Part $\mathrm{I}^{3}$ of this study the nominal process control algorithm for Equation 10 has been tied to operating experience by using the most silica rich sample analyzed at SRTC that was run in the SRS $2 \mathrm{~F}$ evaporator at $140^{\circ} \mathrm{C}$ without scaling (FTF-046 from Tank 46). This sample was from a drop tank and the material was recycled to the feed tank and experienced an evaporation of $36 \%$ confirming the prediction from the model that this sample could undergo an additional $40 \%$ evaporation and remain unsaturated with respect to $\mathrm{NAS}_{\text {gel }}$. Sample FTF-046 intersects the abscissa as indicated by the vertical dashed line in Figure 5 below at $\log \mathrm{Q}(\mathrm{NAS})_{25^{\circ} \mathrm{C}}=-43.26$. All values up to and including FTF-046 remain undersaturated (negative $\mathrm{Q} / \mathrm{K}$ ) with respect to $\mathrm{NAS}_{\text {gel }}$ at $180^{\circ} \mathrm{C}$.

Table VII shows that the saturation values calculated at $120^{\circ} \mathrm{C}$ (Equation 13) and $180^{\circ} \mathrm{C}$ (Equation 14) are bounded within the $95 \%$ bias bands of Equation 10. As long as the errorless value for FTF- 046 at $180^{\circ} \mathrm{C}, \log \mathrm{Q} / \mathrm{K}_{(\mathrm{NAS})}=-4.508$, e.g. is more negative (less saturated) than $\log \mathrm{Q} / \mathrm{K}_{\text {(NAS) }}=-0.576$, the upper $95 \%$ bound of Equation 10, the FTF-046 sample solution is predicted to be undersaturated with respect to the $\mathrm{NAS}_{\text {gel. }}$. This is indeed the case as observed in Table VII.

Three additional samples analyzed in January, 2001 (see Table III samples HTK-480, HTK-481, and HTK-482) from the SRS 3H evaporator confirm the operating limit of log $\mathrm{Q}(\mathrm{NAS})_{25^{\circ} \mathrm{C}}=-43.3$ set using the analysis of sample FTF-046 (the exact number is 43.26). These samples from the SRS 3H evaporator system drop tank (Tank 30) were taken on the same day at different depths. The individual $\log \mathrm{Q}(\mathrm{NAS})_{25^{\circ} \mathrm{C}}$ values are $-44.43,-44.14$, and -41.42 respectively demonstrating the variation with depth in the tank. The average $\log \mathrm{Q}(\mathrm{NAS}){ }_{25^{\circ} \mathrm{C}}$ values for these samples is -43.33 , the same value (to the $1^{\text {st }}$ decimal place) as sample FTF-046 from Tank 46 in the SRS 2F evaporator system. The $3 \mathrm{H}$ samples were also recycled to the drop tank and experienced a $15 \%$ evaporation confirming the prediction from the model that this sample could undergo an additional $40 \%$ evaporation and remain unsaturated with respect to $\mathrm{NAS}_{\mathrm{gel}}$.

Table VII shows that the saturation values calculated at $120^{\circ} \mathrm{C}$ (Equation 13 ) and $180^{\circ} \mathrm{C}$ (Equation 14) for the Tank 30 samples are lower than the upper $95 \%$ model bias given by Equation 10. As long as the errorless value for the pooled Tank 30 samples at $200^{\circ} \mathrm{C}, \log$ $\mathrm{Q} / \mathrm{K}_{\text {(NAS) }}=-4.576$, e.g. is more negative (less saturated) than $\log \mathrm{Q} / \mathrm{K}_{\text {(NAS) }}=-0.628$, the upper $95 \%$ bound of Equation 10, the solution is predicted to be undersaturated with respect to the $\mathrm{NAS}_{\mathrm{gel}}$. This is indeed the case as observed in Table VII. 
WSRC-TR-2002-00318, Rev. 0

Table VII. Calculated Log $(\mathrm{Q} / \mathrm{K})_{\mathrm{NAS}}$ for Operating Limit Samples from Tank 46 and Tank 30 at Varying Temperature

\begin{tabular}{|c|c|c|c|}
\hline Temperature & Equation Used & $\begin{array}{c}\log (\mathrm{Q} / \mathrm{K})_{\mathrm{NAS}} \\
\text { for Sample } \\
\text { FTF-046 from } \\
\text { Tank } 46\end{array}$ & $\begin{array}{c}\log (\mathrm{Q} / \mathrm{K})_{\mathrm{NAS}} \\
\text { for Pooled } \\
\text { Samples HTK- } \\
480,481 \text { and } \\
482 \text { from Tank } \\
30\end{array}$ \\
\hline $120 / 140^{\circ} \mathrm{C}$ pooled data & Upper 95\% Error Equation 10 & -0.576 & -0.628 \\
\hline $180^{\circ} \mathrm{C}$ & Equation 14 & -4.508 & -4.576 \\
\hline $165^{\circ} \mathrm{C}$ & Equation 15 & -4.232 & -4.297 \\
\hline $120 / 140^{\circ} \mathrm{C}$ pooled data & Equation 10 & -5.501 & -5.668 \\
\hline $120^{\circ} \mathrm{C}$ & Equation 13 & -5.662 & -5.729 \\
\hline $120 / 140^{\circ} \mathrm{C}$ pooled data & Lower 95\% Error Equation 10 & -10.426 & -10.504 \\
\hline
\end{tabular}


WSRC-TR-2002-00318, Rev. 0

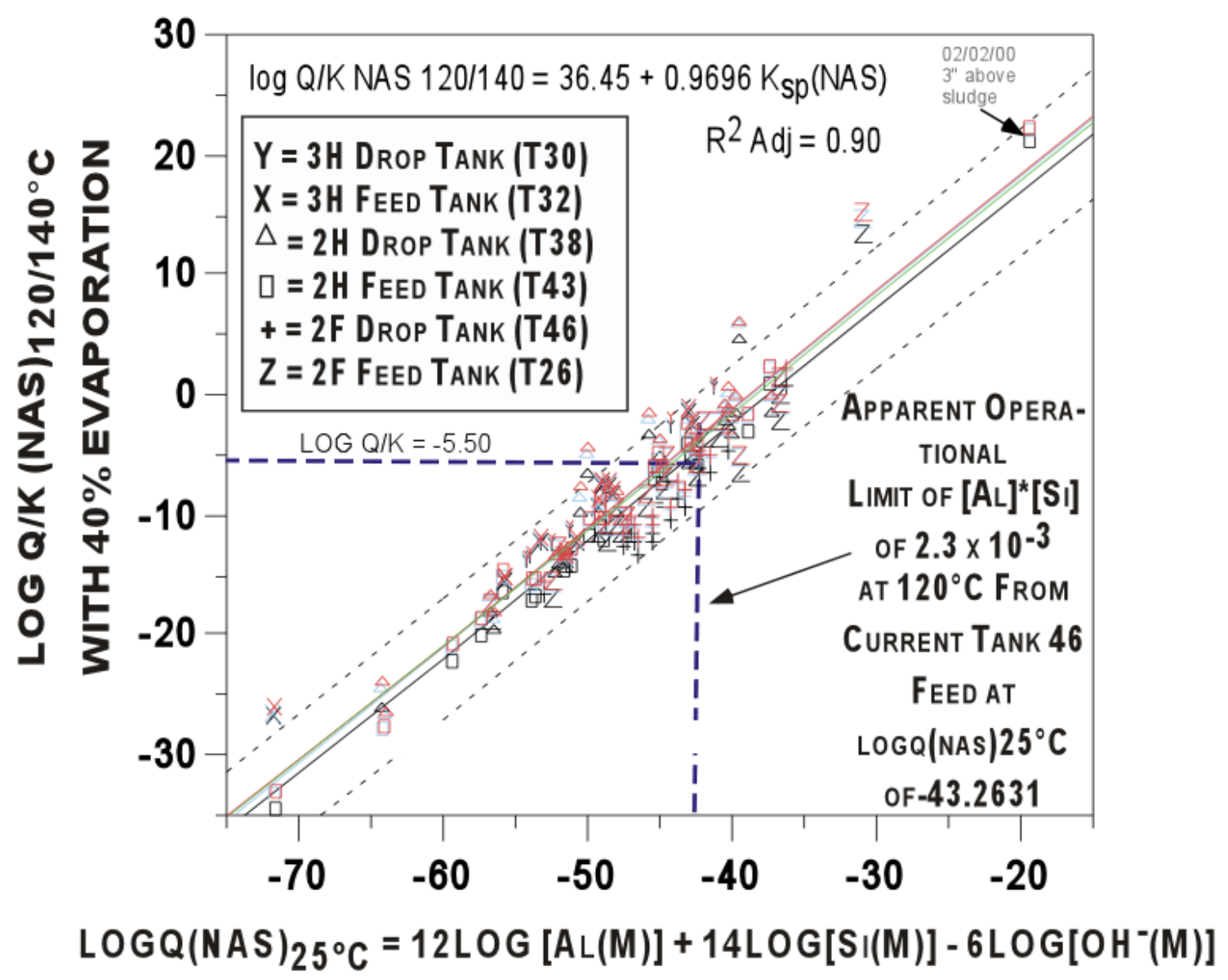

Figure 5. Temperature variation of the nominal process control model. The pooled data set at $120^{\circ} \mathrm{C} / 140^{\circ} \mathrm{C}$ assuming a $40 \mathrm{wt} \%$ evaporation are shown in black with the corresponding upper and lower $95 \%$ error bands shown as black dashed lines. The $140^{\circ} \mathrm{C}$ data for $40 \mathrm{wt} \%$ evaporation are shown in light blue. The $165^{\circ} \mathrm{C}$ data at $40 \mathrm{wt} \%$ evaporation and the corresponding line of best fit are shown in red. The $180^{\circ} \mathrm{C}$ data at $40 \mathrm{wt} \%$ evaporation and the corresponding line of best fit are shown in green. 
In order to quantify the temperature difference for a given tank solution one can subtract Equation 10 derived for the pooled $120 / 140^{\circ} \mathrm{C}$ data from Equation 14 derived at $180^{\circ} \mathrm{C}$ which gives

$$
\Delta \log \mathrm{Q} / \mathrm{K}_{(\mathrm{NAS})}=(37.57-36.45)+(0.9726-0.9696) \log \mathrm{Q}(\mathrm{NAS})_{25^{\circ} \mathrm{C}}
$$

The solution of Equation 17 can then be solved for each of the 101 data samples and plotted as a function of $\log \mathrm{Q}(\mathrm{NAS})_{25^{\circ} \mathrm{C}}($ Figure 6$)$ which gives

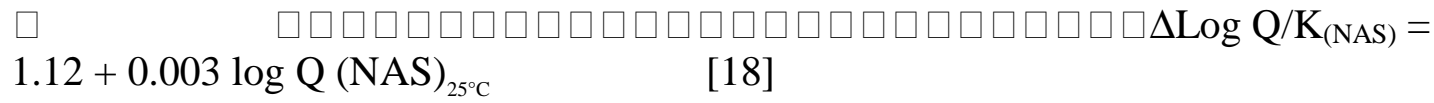

Figure 6 shows that the temperature difference can be a minimum of 0.91 at $\log \mathrm{Q}$ (NAS) ${ }_{25^{\circ} \mathrm{C}}$ values of -70 or a maximum of 1.06 at $\mathrm{K}_{\mathrm{sp}(\mathrm{NAS})}$ of -20 . Solving Equation 18 for sample FTF-046 at a $\mathrm{K}_{\mathrm{sp}(\mathrm{NAS})}=-43.3$ gives a $\Delta \log \mathrm{Q} / \mathrm{K}_{\text {(NAS) }}$ of 0.99 . This indicates that the higher temperature solutions are still undersaturated but they are less undersaturated (by $\log (\mathrm{Q} / \mathrm{K})_{\mathrm{NAS}}=0.91$ to 1.06$)$ than the lower temperature solutions, e.g., they have a more positive $\log \mathrm{Q} / \mathrm{K}_{(\mathrm{NAS})}$.

In conclusion, the temperature effects on the $\log (\mathrm{Q} / \mathrm{K})_{\mathrm{NAS}}$ saturation index are negligible in the temperature range over which the SRS evaporators operate, e.g. $120-180^{\circ} \mathrm{C}$. Since the elevated temperature $\log (\mathrm{Q} / \mathrm{K})_{\mathrm{NAS}}$ values fall within the $95 \%$ bias of the nominal evaporator process model, the errors associated with using the model developed for the pooled $120^{\circ} \mathrm{C} / 140^{\circ} \mathrm{C}$ data for solutions being processed at $165^{\circ} \mathrm{C}$ is sufficiently accounted for. 
WSRC-TR-2002-00318, Rev. 0

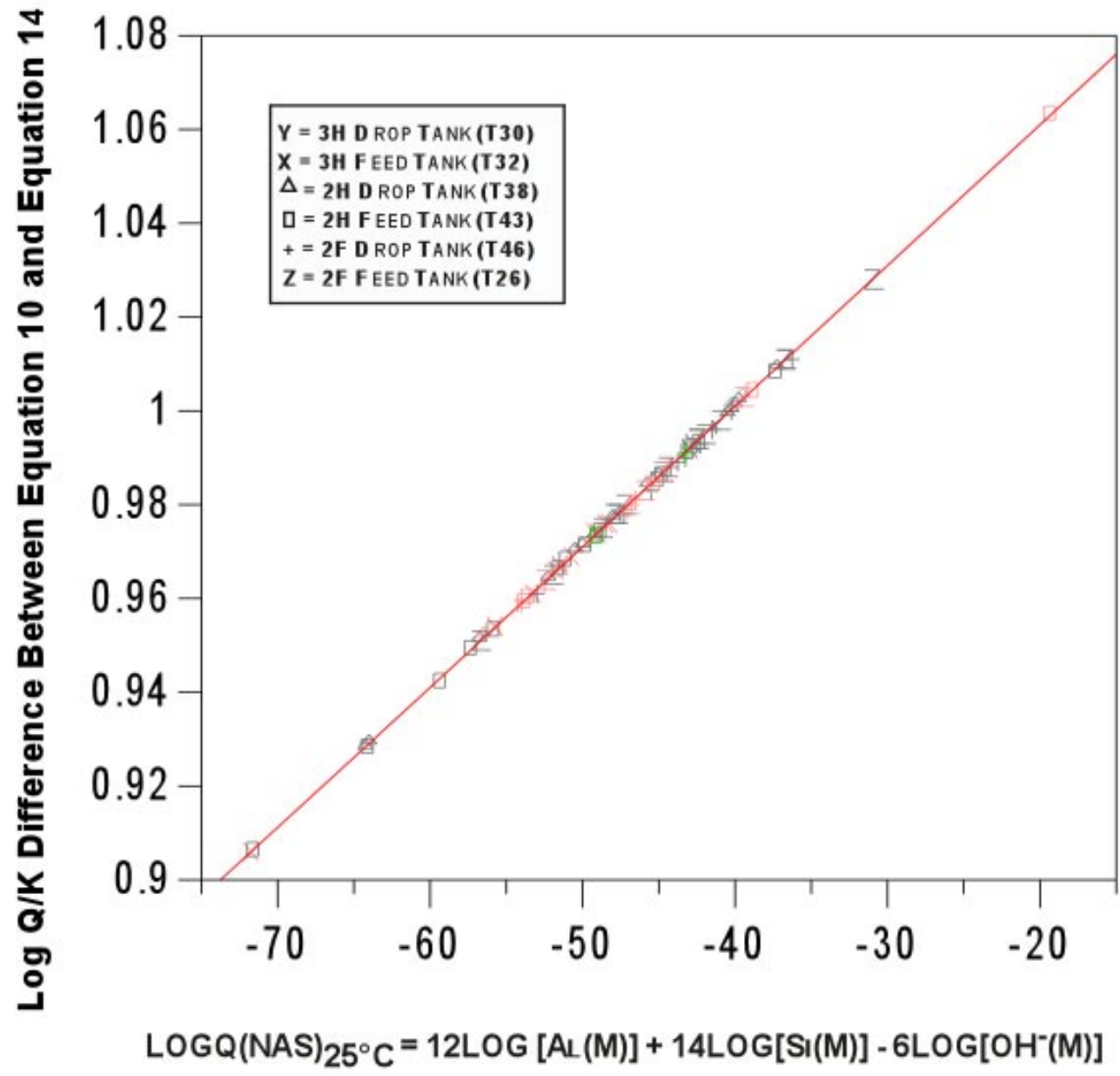

Figure 6. Difference in $\log \mathrm{Q} / \mathrm{K}$ calculation between Equation 10 (pooled $120^{\circ} / 140^{\circ} \mathrm{C}$ ) and Equation $14\left(180^{\circ} \mathrm{C}\right)$. 


\subsection{BOUNDING EVAPORATION PERCENTAGES}

The nominal evaporator process model was generated assuming a nominal evaporation of $40 \mathrm{wt} \%$. During routine operation the evaporators do not always achieve $40 \mathrm{wt} \%$. This is especially true when the evaporator solutions approach their operational target density of $1.6 \mathrm{~g} / \mathrm{cm}^{3}$. Therefore, upper and lower bounds on evaporation were calculated spanning $10 \mathrm{wt} \%$ to $60 \mathrm{wt} \%$ evaporations. Since the temperature effects on the model were shown (see Section 6) to be of minimal impact (shifting the $\log (\mathrm{Q} / \mathrm{K})_{\mathrm{NAS}}$ by only 0.91-1.06), the varying evaporation percentages will be calculated using the pooled $120^{\circ} \mathrm{C} / 140^{\circ} \mathrm{C}$ data set. The calculation for the 101 data points from all the evaporator feed and drop tanks gives the following equations for various evaporation rates:

$$
\begin{aligned}
& \log \mathrm{Q} / \mathrm{K}_{\text {(NAS @ 10 wt \% evaporation) }}=32.80+0.9587 \log \mathrm{Q}(\mathrm{NAS})_{25^{\circ} \mathrm{C}} ; \mathrm{R}^{2}=0.90 \quad \text { [19] } \\
& \log \mathrm{Q} / \mathrm{K}_{(\mathrm{NAS} @ 20 \text { wt \% evaporation })}=33.84+0.9618 \log \mathrm{Q}(\mathrm{NAS})_{25^{\circ} \mathrm{C}} ; \mathrm{R}^{2}=0.90 \quad[20] \\
& \log \mathrm{Q} / \mathrm{K}_{(\mathrm{NAS} @ 30 \mathrm{wt} \% \text { evaporation })}=35.04+0.9653 \log \mathrm{Q}(\mathrm{NAS})_{25^{\circ} \mathrm{C}} ; \mathrm{R}^{2}=0.90 \\
& \log \mathrm{Q} / \mathrm{K}_{(\mathrm{NAS} @ 40 \mathrm{wt} \% \text { evaporation })}=36.45+0.9696 \log \mathrm{Q}(\mathrm{NAS})_{25^{\circ} \mathrm{C}} ; \mathrm{R}^{2}=0.90 \\
& \log \mathrm{Q} / \mathrm{K}_{(\mathrm{NAS} @ 50 \mathrm{wt} \% \text { evaporation })}=38.07+0.9734 \log \mathrm{Q}(\mathrm{NAS})_{25^{\circ} \mathrm{C}} ; \mathrm{R}^{2}=0.90 \\
& \log \mathrm{Q} / \mathrm{K}_{(\mathrm{NAS} @ 60 \mathrm{wt} \% \text { evaporation })}=40.11+0.9786 \log \mathrm{Q}(\mathrm{NAS})_{25^{\circ} \mathrm{C}} ; \mathrm{R}^{2}=0.90
\end{aligned}
$$

Equations 19-23 are shown visually in Figure 8 where they are overlain on Equation 10, the nominal evaporator model for $40 \mathrm{wt} \%$ evaporation. It is interesting to note that the 10-30 wt \% and 50-60 wt \% correlations fall within the 95\% error of the model for the nominal $40 \mathrm{wt} \%$ evaporation model referred to in this study as the nominal evaporator model.

The $\log (\mathrm{Q} / \mathrm{K})_{\mathrm{NAS}}$ values for sample FTF-046 at various evaporations lies within the $95 \%$ bias of the nominal evaporator model assuming that there is no model error. If the model error is considered, which it must be, then the upper $95 \%$ bias for each evaporation percentage will be the limiting value in determining what evaporation a given feed solution can experience without precipitating aluminosilicate scale.

Equations 10 and 19-23 can be solved for varying $\log$ Q (NAS) $)_{25^{\circ} \mathrm{C}}$ values at the varying evaporation percentages (Table VIII). This allows operational flexibility in applying the model to evaporator operations when less than or more than a $40 \%$ nominal evaporation is being performed. The equations can be solved based on the upper $95 \%$ bounding $\log$ $(\mathrm{Q} / \mathrm{K})_{\mathrm{NAS}}$ in Table VII for the nominal evaporator model at $40 \mathrm{wt} \%$ evaporation, e.g. $\log$ $(\mathrm{Q} / \mathrm{K})_{\mathrm{NAS}}=-0.576$. The equations can also be solved based on the $\log (\mathrm{Q} / \mathrm{K})_{\mathrm{NAS}}$ of Equation 10 assuming no model error, e.g. the value of -5.50 . One can, therefore, solve 
Equation 10 and Equations 19-23 assuming $\log (\mathrm{Q} / \mathrm{K})_{\mathrm{NAS}}=-0.576$ or -5.50 because they are equivalent in preventing saturation with respect to aluminosilicate scale, NAS $\mathrm{Nel}_{\text {. }}$. The latter approach is chosen for convenience since the model value of -5.50 is shown in Part $\mathrm{I}^{3}$ of this study and in Figure 4 of this report. The $\log \mathrm{Q}(\mathrm{NAS})_{25^{\circ} \mathrm{C}}$ values for the different evaporation percentages are given in Table VIII and the resulting OLS fit of the data shown in Figure 7.

Table VIII Percent Evaporation Vs. Ksp(NAS) Values for Process Control

\begin{tabular}{|c|c|c|}
\hline Percent Evaporation & $\log (\mathbf{Q} / \mathbf{K})_{\mathbf{N A S}}$ & $\log \mathbf{Q}(\mathbf{N A S})_{\mathbf{2 5}^{\circ} \mathrm{C}}$ \\
\hline 10 & -5.50 & -39.946 \\
\hline 20 & -5.50 & -40.906 \\
\hline 30 & -5.50 & -41.995 \\
\hline 40 & -5.50 & -43.260 \\
\hline 50 & -5.50 & -44.762 \\
\hline 60 & -5.50 & -46.611 \\
\hline
\end{tabular}

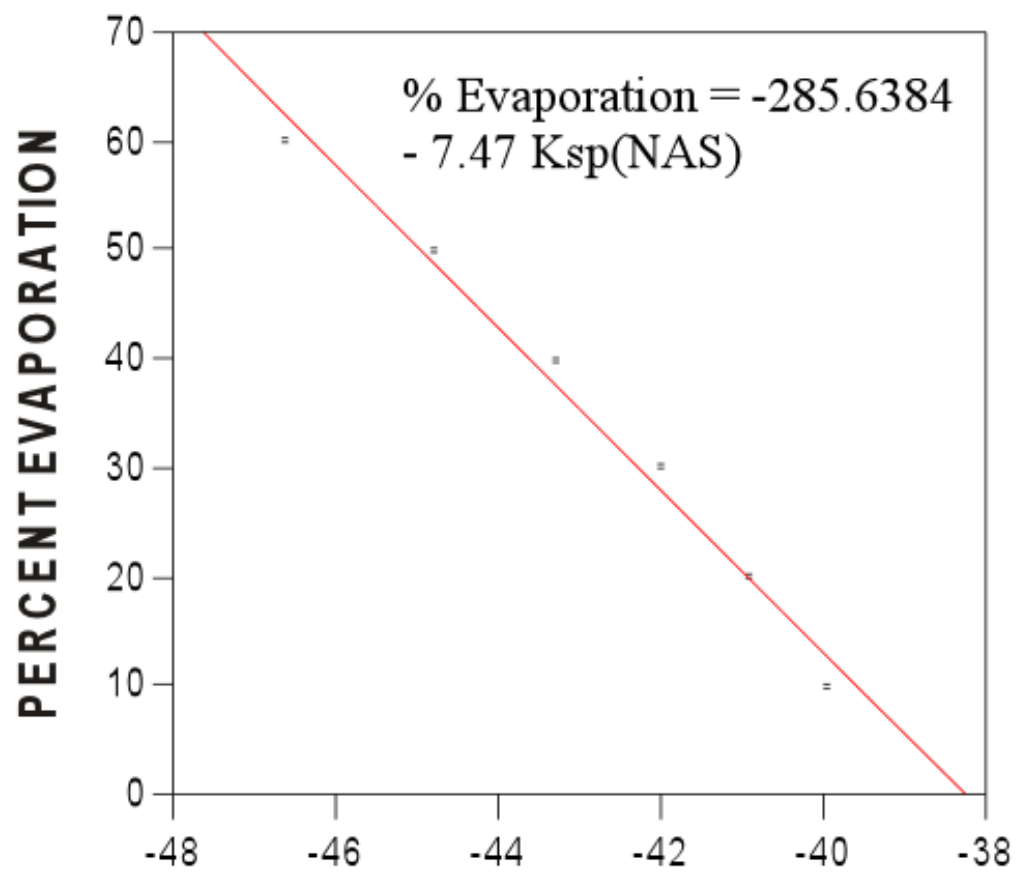

$\left.\operatorname{LOGQ}(\mathrm{NAS}) 25^{\circ} \mathrm{C}=12 \mathrm{LOG}[\mathrm{AL}(\mathrm{M})]+14 \mathrm{LOG}[\mathrm{SI}(\mathrm{M})]-6 \mathrm{LOG}^{-} \mathrm{OH}^{-}(\mathrm{M})\right]$

Figure 7. Relation of $\log \mathrm{Q}(\mathrm{NAS})_{25^{\circ} \mathrm{C}}$ to percent evaporation for process control. 
WSRC-TR-2002-00318, Rev. 0

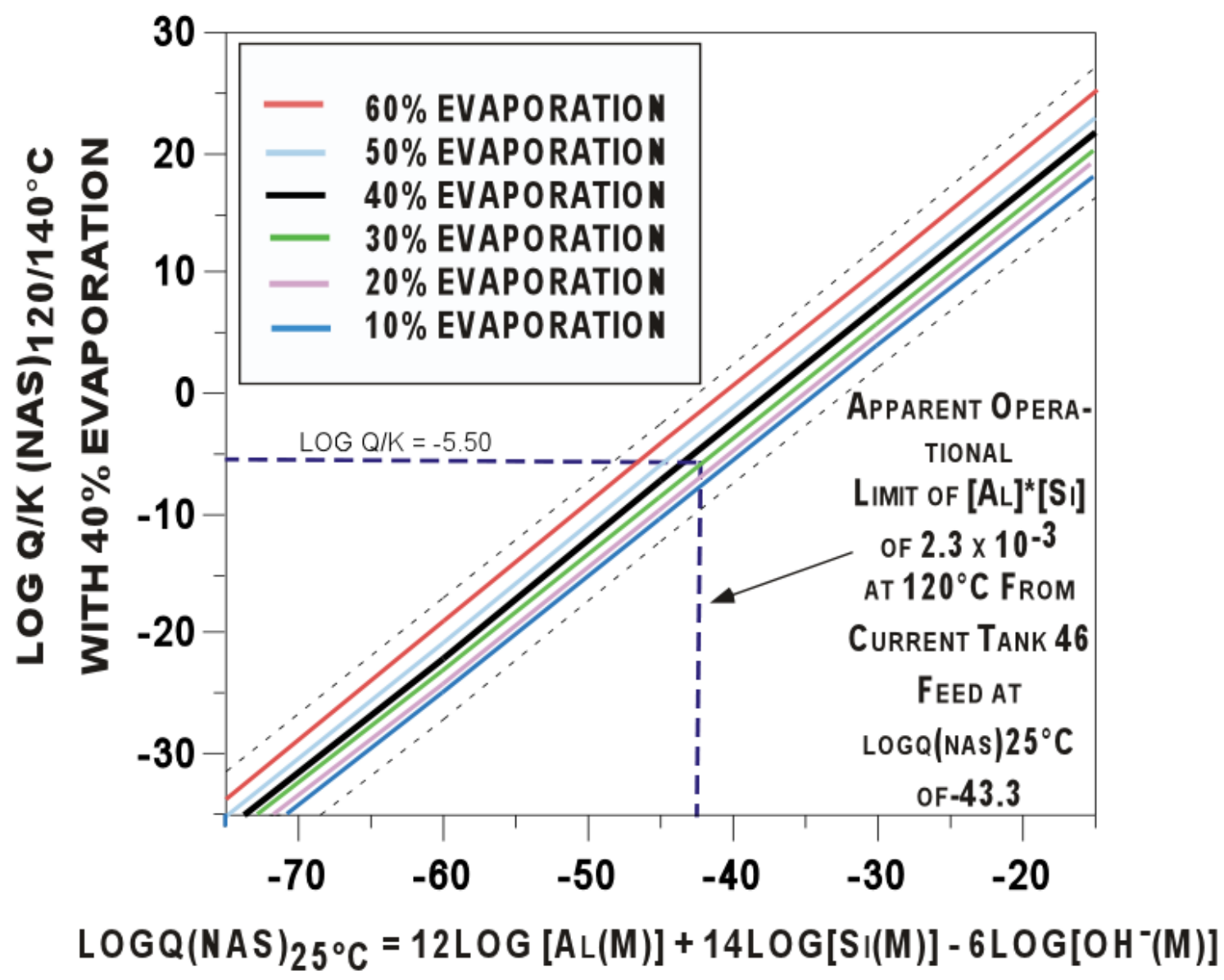

Figure 8. Evaporator model at various weight percent evaporations varying from $10 \%$ to $60 \%$. Note that the 10 to $60 \mathrm{wt} \%$ evaporations fall within the $95 \%$ model bias bounds of the nominal $40 \mathrm{wt} \%$ evaporation model. 


\subsection{BOUNDING COMPOSITIONS ${ }^{13}$}

Geochemist's Workbench (GWB) has been used to estimate the $\log (\mathrm{Q} / \mathrm{K})_{\mathrm{NAS}}$ for a number of components in the evaporator based upon 101 evaporator chemistries and comparative process histories (Part $\mathrm{I}^{3}$ of this study). The ranges covered in the study to date are provided in Table IX. The $\mathrm{NO}_{2}$ and $\mathrm{NO}_{3}$ values are grouped because this is the way they will are treated in GWB. Na was omitted because the Na value was a calculated value from mass balance considerations (see Equation 11c). This left 12 composition parameters, plus temperature, plus evaporation as 14 of the allowable 16 parameters for the OLH analysis (see Section 2.3 for discussion).

Table IX. Ranges Modeled in Part I and Part II of This Study

\begin{tabular}{|l|r|r|}
\hline & Minimum (M) & Maximum (M) \\
\hline $\mathrm{Al}(\mathrm{M})$ & 0.005 & 3.000 \\
\hline $\mathrm{Cl}(\mathrm{M})$ & 0.0014 & 0.12 \\
\hline $\mathrm{CO}_{3}(\mathrm{M})$ & 0.005 & 0.62 \\
\hline $\mathrm{C}_{2} \mathrm{O}_{4}(\mathrm{M})$ & 0.0012 & 0.15 \\
\hline $\mathrm{F}(\mathrm{M})$ & 0.00000526 & 0.012 \\
\hline $\mathrm{Fe}(\mathrm{M})$ & 0 & 0.358 \\
\hline $\mathrm{NO}_{2}(\mathrm{M})$ & 0.273 & 2.975 \\
\hline $\mathrm{NO}_{3}(\mathrm{M})$ & 0.300 & 3.423 \\
\hline$\left[\mathrm{NO}_{2}\right]+\left[\mathrm{NO}_{3}\right]$ & 0.654 & 5.343 \\
\hline $\mathrm{OH}_{(\mathrm{M})}$ & 0.5 & 15.2 \\
\hline $\mathrm{K}(\mathrm{M})$ & 0.001215 & 0.18 \\
\hline $\mathrm{PO}_{4}(\mathrm{M})$ & 0.0025 & 0.0546 \\
\hline $\mathrm{SO}(\mathrm{M})$ & 0.0026 & 0.0821 \\
\hline $\mathrm{Si}(\mathrm{M})$ & 0.00002136 & 0.1436588 \\
\hline $\mathrm{U}(\mathrm{M})$ & $8.025 \mathrm{E}-07$ & 0.0155 \\
\hline $\mathrm{Na}(\mathrm{M})$ & 1.416 & 18.616 \\
\hline
\end{tabular}

Reasonable maximum concentrations for $\left[\mathrm{NO}_{2}\right],\left[\mathrm{NO}_{3}\right]$, and $[\mathrm{OH}]$ in the tank farm were determined ${ }^{f}$ to be $4 \mathrm{M}, 7 \mathrm{M}$, and $16 \mathrm{M}$, respectively. Wider ranges had been previously suggested earlier and then revised. Therefore, upper concentration bounds for $\left[\mathrm{NO}_{2}\right]$, $\left[\mathrm{NO}_{3}\right]$, and $[\mathrm{OH}]$ of $6 \mathrm{M}, 7 \mathrm{M}$, and $16 \mathrm{M}$ were used as a reasonable compromise. In addition, the temperature was varied between $40^{\circ} \mathrm{C}$ and $180^{\circ} \mathrm{C}$ and the evaporation percentage between 0 and $80 \%$.

${ }^{f}$ D.T. Hobbs of SRTC 
In Part $\mathrm{I}^{3}$ of this study it was determined that the undersaturated $\log (\mathrm{Q} / \mathrm{K})_{\mathrm{NAS}}$ values were found either when the [Si] or [Al] concentrations were very low. Furthermore, because the predictions should be strong functions of the $\ln ([])$ values (and the concentrations, if measured, would likely be more lognormal than Gaussian in nature), the Orthogonal Latin Hypercube $(\mathrm{OLH})$ designs were developed using $\ln ([])$ values. These are provided in Table $\mathrm{X}$ (where because the minimum [Fe] was 0.0 , the minimum concentration for all those shown in the table — which is that for [U] — was substituted for the minimum $[\mathrm{Fe}]$ ).

Table X. Tank Farm Bounding Regions Including Logarithmic Transformations Assumed in the OLH Statistical Analysis

\begin{tabular}{|c|c|c|c|c|}
\hline & Min & $\operatorname{Min}(\log )^{*}$ & Max & $\operatorname{Max}(\log )^{*}$ \\
\hline $\mathrm{Al}(\mathrm{M})$ & 0.005 & -2.3010 & 4 & 0.6021 \\
\hline $\mathrm{Cl}(\mathrm{M})$ & 0.00020 & -3.6990 & 0.12 & -0.9208 \\
\hline $\mathrm{CO}_{3}(\mathrm{M})$ & 0.005 & -2.3010 & 2.875 & 0.4586 \\
\hline $\mathrm{C}_{2} \mathrm{O}_{4}(\mathrm{M})$ & 0.0005 & -3.3010 & 0.15 & -0.8239 \\
\hline$\left[\mathrm{CO}_{3}\right]+\left[\mathrm{C}_{2} \mathrm{O}_{4}\right]$ & 0.0055 & -2.2596 & 3.025 & 0.4807 \\
\hline $\mathrm{F}(\mathrm{M})$ & 0.00000526 & -5.2840 & 0.2415 & -0.6171 \\
\hline $\mathrm{Fe}(\mathrm{M})$ & 0 & -6.3010 & 0.3581021 & -0.4460 \\
\hline $\mathrm{NO}_{2}(\mathrm{M})$ & 0.0921 & -1.0357 & 6.0 & 0.7782 \\
\hline $\mathrm{NO}_{3}(\mathrm{M})$ & 0.0173 & -1.7620 & 7.0 & 0.8451 \\
\hline$\left[\mathrm{NO}_{2}\right]+\left[\mathrm{NO}_{3}\right]$ & 0.1094 & -0.9610 & 13 & 1.1139 \\
\hline $\mathrm{OH}(\mathrm{M})$ & 0.01 & -2.000 & 16 & 1.2041 \\
\hline $\mathrm{K}(\mathrm{M})$ & 0.001215 & -2.9154 & 0.5 & -0.3010 \\
\hline $\mathrm{PO}_{4}(\mathrm{M})$ & 0.0005 & -3.3010 & 0.145 & -0.8386 \\
\hline $\mathrm{SO}_{4}(\mathrm{M})$ & 0.0005 & -3.3010 & 0.8875 & -0.0518 \\
\hline Si (M) & 0.00002136 & -4.6716 & 0.1785714 & -0.7482 \\
\hline $\mathrm{U}(\mathrm{M})$ & $5.00 \mathrm{E}-07$ & -6.3010 & 0.0155 & -1.8097 \\
\hline $\mathrm{Na}(\mathrm{M})$ & 0.2015 & -0.6957 & 23 & 1.3617 \\
\hline
\end{tabular}

The optimized design resulting from the natural logarithmic-transformed ranges in Table $\mathrm{X}$ (see footnote) are provided in Table IX. The molar concentrations in these design matrices were then transformed into their corresponding molal concentrations; the total dissolved solids (TDS) values, specific gravities, and molal concentrations were estimated; and then the values were run through GWB. The GWB results for the optimized designs are provided in Table XII (and Figure 9), respectively. The results do an excellent job of covering the saturation points (i.e., $\log (\mathrm{Q} / \mathrm{K})_{\mathrm{NAS}}=0$ ) for the $\mathrm{NAS}_{\mathrm{gel}}$ phase as shown in Figure 9. Also the biases in the model predictions appear to be reasonably distributed for the optimized design; however, this may provide a false sense of security as all deviations shown are biases and not the random measurement errors normally associated with such plots. 
The OLH design indicates that the evaporator control model will cover the bounding composition range indicated in Table $\mathrm{X}$.

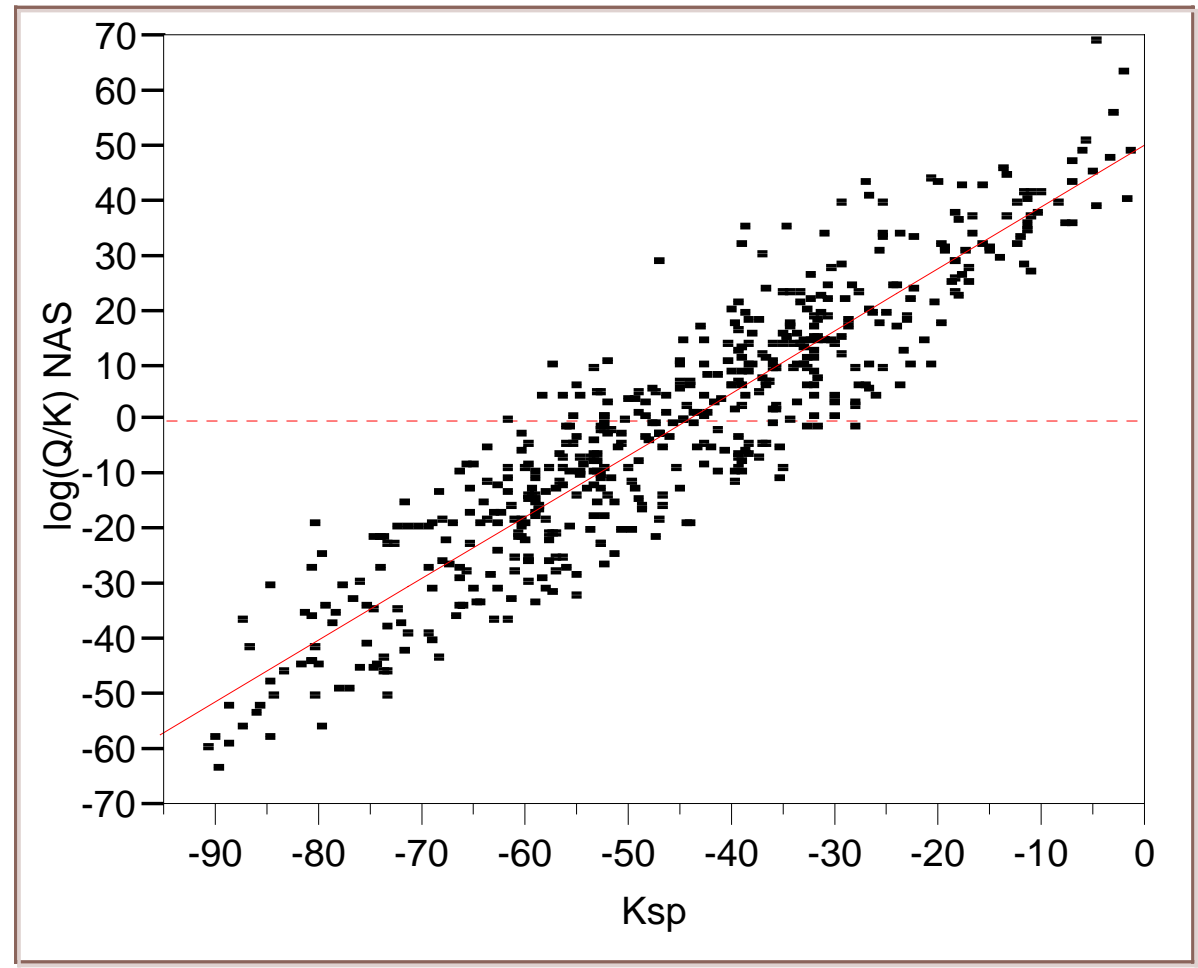

\section{Linear Fit}

$\log (\mathrm{Q} / \mathrm{K}) \mathrm{NAS}=50.283366+1.1324382 \mathrm{Ksp}$

$\begin{array}{cc}\text { Summary of Fit } & \\ \text { RSquare } & 0.844761 \\ \text { RSquare Adj } & 0.844457 \\ \text { Root Mean Square Error } & 9.540176 \\ \text { Mean of Response } & -1.51016 \\ \text { Observations (or Sum Wgts) } & 513\end{array}$

Figure 9. Bivariate Fit of $\log \mathrm{Q} / \mathrm{K}$ for $\mathrm{NAS}_{\text {gel }}$ versus $\log \mathrm{Q}(\mathrm{NAS})_{25^{\circ} \mathrm{C}}\left(\mathrm{K}_{\mathrm{sp}}\right)$ for the optimized Orthogonal Latin Hypercube model. 
WSRC-TR-2002-00318, Rev. 0

Table XI. OLH Logarithm-Based Design Matrix Corresponding to the Optimized T Matrix (concentrations are molar)

\begin{tabular}{|c|c|c|c|c|c|c|c|c|c|c|c|c|c|c|c|}
\hline $\mathrm{Al}$ & $\mathrm{Cl}$ & $\mathrm{CO}_{3}$ & $\mathrm{C}_{2} \mathrm{O}_{4}$ & $\mathrm{~F}$ & $\mathrm{Fe}$ & $\mathrm{NO}_{2}$ & $\mathrm{NO}_{3}$ & $\mathrm{OH}$ & $\mathrm{K}$ & $\mathrm{PO}_{4}$ & $\mathrm{SO}_{4}$ & $\mathrm{Si}$ & $\mathrm{U}$ & $\mathrm{T}\left({ }^{\circ} \mathrm{C}\right)$ & $\mathrm{Ev}$ \\
\hline 0.446 & 000 & 116 & 005 & 504 & 000 & 262 & 028 & & 39 & & 682 & $\overline{22}$ & 62 & 42.5 & .455 \\
\hline & & & & & & & & & & & & & & & \\
\hline 318 & 01 & & & & & & & & & & & & & & \\
\hline 1.188 & 011 & & .006 & 0000 & & & 019 & & & & & 0.000 & & & .089 \\
\hline ( 226 & & 4 & 053 & 000 & & 03 & & 182 & & 01 & 260 & & & & 552 \\
\hline & & & & & & & & & & & & & & & \\
\hline & & & .076 & & & 45 & 775 & & & & & & & & 745 \\
\hline 0.272 & 119 & 187 & 0.023 & 0002 & 0000 & .563 & 099 & 0.013 & 043 & 0.029 & 002 & .000 & 0000 & 65.2 & 150 \\
\hline 0.392 & 000 & 006 & .005 & & & .095 & 070 & .032 & & 0.013 & .003 & & & 168.2 & .700 \\
\hline 2. & & & 005 & & & $1 / 0$ & & & & & & & & 18.0 & 273 \\
\hline & & & 004 & & & & & & & & & & & & 508 \\
\hline 510 & 069 & 16 & 0.001 & & & .616 & & 0.222 & & 0.001 & 325 & 00 & & 94.1 & 105 \\
\hline 3.081 & 002 & 063 & 0.134 & 0344 & & 326 & 064 & & & 0.002 & 012 & 0.041 & & 2.0 & .714 \\
\hline & & & & & & & & & & & & & & & .338 \\
\hline & & & 112 & & & & & & & & & & & & 556 \\
\hline & 11 & 43 & or & & & & & & & 137 & & & & & 75 \\
\hline 63 & 001 & 011 & 0.004 & 001 & 017 & 475 & 071 & 0.039 & 048 & 0.010 & 023 & 0.000 & & & 717 \\
\hline & 006 & & ( & & & & & & & & & & & & 219 \\
\hline & & & & & & & & & & & & & & & 531 \\
\hline & & & & & & & & & & & & & & & 320 \\
\hline & 001 & & 073 & & & 092 & & & & 0.008 & & 01 & & 7 & 866 \\
\hline 301 & 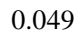 & 20 & .018 & & & 0.160 & & 0.389 & & 0.041 & & & & & 267 \\
\hline & & & & & & & & & & & & & & & 791 \\
\hline & & & & & & & & & & & & & & & \\
\hline & 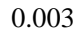 & & 2 & & & & & & & & & & & & 61 \\
\hline & & & & & & & & & & & & & & & \\
\hline & 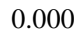 & & or & & & & & & & & & & & & 516 \\
\hline & & & & & & & & & & & & & & & 116 \\
\hline & & & & & & & & & & & & & & & \\
\hline & & & 1 & & & & & & & & & & & & \\
\hline & & & & & & & & & & & & & & & \\
\hline & & & & & & & & & & & & & & & 288 \\
\hline & & & & & & & & & & & & & & & 667 \\
\hline & & & & & & & & & & & & & & & \\
\hline & & & & & & & & & & & & & & & 558 \\
\hline & & & & & & & & & & & & & & & \\
\hline & & & & & & & & & & & & & & & 88 \\
\hline & & & & & & & & & & & & & & & \\
\hline & & & & & & & & & & & & & & & \\
\hline & & & & & & & & & & & & & & & \\
\hline & & & & & & & & & & & & & & & 639 \\
\hline & & & & & & & & & & & & & & & 28 \\
\hline & & & & & & & & & & & & & & & \\
\hline & & & & & & & & & & & & & & & \\
\hline & & & & & & & & & & & & & & & \\
\hline & & & & & & & & & & & & & & & 19 \\
\hline & & & & & & & & & & & & & & & \\
\hline & & & & & & & & & & & & & & & \\
\hline & & & & & & & & & & & & & & & \\
\hline & & & & & & & & & & & & & & & \\
\hline & & & & & & & & & & & & & & & 147 \\
\hline & & & & & & & & & & & & & & & \\
\hline & & & & & & & & & & & & & & & \\
\hline & & & & & & & & & & & & & & & \\
\hline & & & & & & & & & & & & & & & 420 \\
\hline & & & & & & & & & & & & & & & 128 \\
\hline & & & & & & & & & & & & & & & \\
\hline & & & & & & & & & & & & & & & \\
\hline & & & & & & & & & & & & & & & \\
\hline & & & & & & & & & & & & & & & 370 \\
\hline & & & & & & & & & & & & & & 157.0 & 494 \\
\hline & & & & & & & & & & & & & & & \\
\hline & & & & & & & & & & & & & & & \\
\hline 0.752 & 0.023 & 32 & 0.013 & 22 & 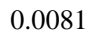 & 4 & 72 & 22 & 5 & 095 & 231 & 23 & 018 & 68.4 & 0.253 \\
\hline
\end{tabular}


WSRC-TR-2002-00318, Rev. 0

\begin{tabular}{|c|c|c|c|c|c|c|c|c|c|c|c|c|c|c|c|}
\hline $\mathrm{Al}$ & $\mathrm{Cl}$ & $\mathrm{CO}_{3}$ & $\mathrm{C}_{2} \mathrm{O}_{4}$ & $\mathrm{~F}$ & $\mathrm{Fe}$ & $\mathrm{NO}_{2}$ & $\mathrm{NO}_{3}$ & $\mathrm{OH}$ & $\mathrm{K}$ & $\mathrm{PO}_{4}$ & $\mathrm{SO}_{4}$ & $\overline{\mathrm{Si}}$ & $\bar{U}$ & $\mathrm{~T}\left({ }^{\circ} \mathrm{C}\right)$ & Evap \\
\hline 0.186 & 004 & 023 & 002 & 0003 & 000 & & 1.561 & .103 & 17 & & & 44 & .0028 & 100.4 & .586 \\
\hline & & & & & & & & & & & & & & & \\
\hline & & & & & & & & & & & & & & & 416 \\
\hline 792 & 026 & & 001 & & & & & & & & & 01 & & .4 & .059 \\
\hline 2.110 & 002 & & 020 & & & 390 & 245 & & & & & 0.052 & & 83.5 & .589 \\
\hline 0458 & 065 & & 0030 & & & & 805 & 0020 & & & & & & & 238 \\
\hline & & & & & & & & & & & & & & & 539 \\
\hline 695 & 010 & & 0.011 & & & 311 & & & & & & & & 53.8 & 144 \\
\hline 3.246 & 000 & 028 & 0.004 & 0145 & 001 & 243 & 679 & 0.033 & 029 & .067 & 002 & 0.012 & & 57.5 & .733 \\
\hline 3.001 & 098 & .020 & 0.001 & & & & 905 & 0.332 & & 0.001 & 672 & 0.001 & & 132.1 & .220 \\
\hline 915 & 001 & & .002 & & & 720 & 360 & 0.023 & & 10 & & & & 73.6 & 561 \\
\hline 60 & 29 & & 002 & & & & & 027 & & 01 & & & & & 309 \\
\hline & 001 & & 0.032 & & & 228 & & & & 001 & & & & & 583 \\
\hline 0.626 & 023 & & .043 & & & & & & & & & & & & 047 \\
\hline 2.082 & 002 & & 0.117 & & & & & & & 0.006 & & & & & .739 \\
\hline & 064 & & 12 & & & & & & & 14 & & & & & 033 \\
\hline & 05 & & 004 & & & & 663 & 21 & & 92 & & & & & 550 \\
\hline & 557 & & 006 & & & & & & & 01 & & & & & 377 \\
\hline 3.289 & 004 & & .003 & & & 094 & & & & & & & & & 520 \\
\hline & & & & & & & & & & & & & & & 191 \\
\hline & & & & & & & & & & & & & & & 530 \\
\hline & 013 & & & & & & & & & & & & & & \\
\hline בר20 & 002 & & 0 & & & & & & & & & & & & \\
\hline 0.330 & 008 & & 0.077 & & & & & & & & & & & & 156 \\
\hline & & & & & & & & & & & & & & & \\
\hline & & & & & & & & & & & & & & & \\
\hline & & & & & & & & & & & & & & & \\
\hline & (n) & & 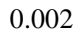 & & & & & & & & & & & & \\
\hline & 002 & & 05 & & & & & & & & & & & & \\
\hline & & & & & & & & & & & & & & & 02 \\
\hline & & & 0 & & & & & & & & & & & & 195 \\
\hline & & & & & & & & & & & & & & & \\
\hline 3.204 & $0 r$ & & 002 & & & & & & & & & & & & \\
\hline & & & & & & & & & & & & & & & \\
\hline & & & & & & & & & & & & & & & \\
\hline & & & & & & & & & & & & & & & \\
\hline & & & & & & & & & & & & & & & \\
\hline & & & & & & & & & & & & & & & \\
\hline & & & & & & & & & & & & & & & 569 \\
\hline & & & & & & & & & & & & & & & \\
\hline & & & & & & & & & & & & & & & \\
\hline & & & & & & & & & & & & & & & \\
\hline & & & & & & & & & & & & & & & 03 \\
\hline & & & & & & & & & & & & & & & \\
\hline & & & & & & & & & & & & & & & \\
\hline & & & & & & & & & & & & & & & \\
\hline & & & & & & & & & & & & & & & 189 \\
\hline & & & & & & & & & & & & & & & \\
\hline & & & & & & & & & & & & & & & \\
\hline & & & & & & & & & & & & & & & \\
\hline & & & & & & & & & & & & & & & \\
\hline & & & & & & & & & & & & & & & 08 \\
\hline & & & & & & & & & & & & & & & \\
\hline & & & & & & & & & & & & & & & \\
\hline & & & & & & & & & & & & & & & \\
\hline & & & & & & & & & & & & & & & \\
\hline & & & & & & & & & & & & & & & 772 \\
\hline & & & & & & & & & & & & & & & \\
\hline & & & & & & & & & & & & & & & \\
\hline & & & & & & & & & & & & & & & \\
\hline & & & & & & & & & & & & & & & \\
\hline & & & & & & & & & & & & & & & 208 \\
\hline & & & & & & & & & & & & & & & \\
\hline & & & & & & & & & & & & & & & \\
\hline & & & & & & & & & & & & & & & \\
\hline & & & & & & & & & & & & & & & 705 \\
\hline & & & & & & & & 39 & & & & & & 146.9 & 303 \\
\hline & & & & & & & & & & & & & & & \\
\hline & & & & & & & & & & & & & & 66.6 & \\
\hline & & & & & & 0.198 & 0.020 & 843 & & 0.036 & .001 & 0.002 & 0.000 & 35.4 & \\
\hline
\end{tabular}


WSRC-TR-2002-00318, Rev. 0

\begin{tabular}{|c|c|c|c|c|c|c|c|c|c|c|c|c|c|c|c|}
\hline $\mathrm{Al}$ & $\mathrm{Cl}$ & $\mathrm{CO}_{3}$ & $\mathrm{C}_{2} \mathrm{O}_{4}$ & $\mathrm{~F}$ & $\mathrm{Fe}$ & $\mathrm{NO}_{2}$ & $\mathrm{NO}_{3}$ & $\mathrm{OH}$ & K & $\mathrm{PO}_{4}$ & $\mathrm{SO}_{4}$ & $\mathrm{Si}$ & $\mathrm{U}$ & $\mathrm{T}\left({ }^{\circ} \mathrm{C}\right)$ & Evap \\
\hline 2.533 & 001 & 161 & 109 & 0002 & 0003 & 10 & 201 & & .007 & 01 & & 059 & .0001 & 25.3 & .002 \\
\hline 142 & & 100 & 13 & 000 & 000 & & 021 & & & & 001 & & & 76.6 & 478 \\
\hline & & & & & & & & & & & & & & & \\
\hline 77 & & & & & & & & & & & & 00 & & 46.0 & 759 \\
\hline & & & & & & & & & & & & & & & .069 \\
\hline & & & .001 & & & & & & & & & .000 & & 77.7 & .784 \\
\hline 51 & & & 771 & & & & & & & & & & & 44.2 & 031 \\
\hline & & & & & & & & & & & & & & 78.8 & 503 \\
\hline & & & & & & & & & & & & & & 66.3 & 247 \\
\hline 0.174 & & & 074 & & & & & & & & & & & 90.9 & .481 \\
\hline 2.002 & & & 001 & & & & & & & & & .000 & & 163.6 & .383 \\
\hline 13 & & & & & & & & & & & & & & 8.4 & 625 \\
\hline & & & 03 & & & & & & & & & & & & \\
\hline & & & 01 & & & & & & & & & & & & 698 \\
\hline 1.542 & & & 015 & & & & & & & & & & & 30.5 & .113 \\
\hline & & & & & & & & & & & & & & 86.2 & 666 \\
\hline & & & & & & & & & & & & & & 0.1 & 172 \\
\hline & & & & & & & & & & & & & & 92.2 & \\
\hline & & & & & & & & & & & & & & & 127 \\
\hline & & & 001 & & & & & & & & & & & 72.0 & 442 \\
\hline & & & & & & & & & & & & & & & 019 \\
\hline & & & & & & & & & & & & & & 67.1 & 716 \\
\hline & & & & & & & & & & & & & & & 158 \\
\hline & & & 020 & & & & & & & & & & & & 431 \\
\hline & & & & & & & & & & & & & & & 331 \\
\hline & & & & & & & & & & & & & & & 519 \\
\hline & & & & & & & & & & & & & & 75.4 & 225 \\
\hline & & & & & & & & & & & & & & 69.8 & 19 \\
\hline 1210 & 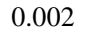 & 10 & 0.002 & & & & & & & & & & & & 011 \\
\hline & & & & & & & & & & & & & & 47.7 & 428 \\
\hline & & & & & & & & & & & & & & & 56 \\
\hline & & & & & & & & & & & & & & & 634 \\
\hline & & & & & & & & & & & & & & & 17 \\
\hline 0157 & & & & & & & & & & & & & & .5 & 484 \\
\hline & & & & & & & & & & & & & & & \\
\hline & & & & & & & & & & & & & & & 36 \\
\hline & & & & & & & & & & & & & & & \\
\hline & & & & & & & & & & & & & & & 300 \\
\hline & & & & & & & & & & & & & & & 08 \\
\hline & & & & & & & & & & & & & & & 797 \\
\hline & & & & & & & & & & & & & & & 94 \\
\hline & & & & & & & & & & & & & & & \\
\hline & & & & & & & & & & & & & & .3 & 350 \\
\hline & & & & & & & & & & & & & & & 59 \\
\hline & & & & & & & & & & & & & & & \\
\hline & & & & & & & & & & & & & & .4 & \\
\hline & & & & & & & & & & & & & & & 364 \\
\hline & & & & & & & & & & & & & & & 405 \\
\hline & & & & & & & & & & & & & & & 117 \\
\hline & & & & & & & & & & & & & & & \\
\hline & & & & & & & & & & & & & & & 47 \\
\hline & & & & & & & & & & & & & & 74.2 & 713 \\
\hline & & & & & & & & & & & & & & & 81 \\
\hline & & & & & & & & & & & & & & & \\
\hline & & & & & & & & & & & & & & & \\
\hline & & & & & & & & & & & & & & 48.8 & \\
\hline & & & & & & & & & & & & & & 169.1 & 0.206 \\
\hline & & & & & & & & & & & & & & .5 & 600 \\
\hline & & & & & & & & & & & & & & & \\
\hline & & & & & & & & & & & & & & & \\
\hline & & & & & & & & & & & & & & & \\
\hline & & & & & & & & & & & & & & & 0.606 \\
\hline & & & & & & & & & & & & & & 0.2 & 077 \\
\hline & & & & & & & & & & & & & & & \\
\hline & & & & & & & & & & & & & & & \\
\hline & & & & & & & & & & & & & & 3.7 & \\
\hline & & & 001 & & & & & 15. & & & & & & 88.7 & 025 \\
\hline & & & & & & & & & & & & & & 172.9 & 766 \\
\hline & & & & & & & & & & & & & & 52.0 & \\
\hline & & & & & 700 & & 01 & /ככ. & & .001 & 092 & 0.000 & .0000 & 77.3 & \\
\hline
\end{tabular}


WSRC-TR-2002-00318, Rev. 0

\begin{tabular}{|c|c|c|c|c|c|c|c|c|c|c|c|c|c|c|c|}
\hline $\mathrm{Al}$ & $\mathrm{Cl}$ & $\mathrm{CO}_{3}$ & $\mathrm{C}_{2} \mathrm{O}_{4}$ & $F$ & $\mathrm{Fe}$ & $\mathrm{NO}_{2}$ & $\mathrm{NO}_{3}$ & $\mathrm{OH}$ & $\mathrm{K}$ & $\mathrm{PO}_{4}$ & $\mathrm{SO}_{4}$ & $\overline{\mathrm{Si}}$ & U & $\mathrm{T}\left({ }^{\circ} \mathrm{C}\right)$ & Evap \\
\hline 0.652 & 000 & 006 & .017 & 089 & 000 & 096 & .576 & .714 & 57 & & & 63 & $\overline{003}$ & 45.5 & 205 \\
\hline & & & & & & & & & & & & & & & \\
\hline 104 & & & & & & & & & & & & & & .2 & 078 \\
\hline 041 & 074 & 12 & 93 & & & & & 0.634 & & 26 & & 00 & & 24.2 & .509 \\
\hline & 004 & & & & & & & & & & & & & & .094 \\
\hline 0.172 & 016 & 046 & 0005 & & & 467 & 754 & 1.066 & & & & & & & .409 \\
\hline & & & & & & & & & & & & & & & \\
\hline 813 & 013 & 395 & 0.003 & & & 647 & 328 & 0.936 & & 05 & & & & 162.2 & 411 \\
\hline 0.418 & 001 & 017 & 0.039 & 0000 & 019 & 119 & 151 & 16.000 & 25 & 0.003 & 050 & .000 & 001 & 59.7 & .283 \\
\hline 0.515 & 014 & & 0.020 & & & .731 & 309 & 6.006 & & 0.045 & 001 & 0.028 & .0001 & 156.5 & .536 \\
\hline 0.268 & 001 & & Ut & & & 235 & & 3.524 & & 01 & & & & 70.1 & 342 \\
\hline 1.084 & 09 & & Don & & & 14 & 992 & 484 & & & & & & & 502 \\
\hline 166 & 001 & & 0.002 & & & & & 0.871 & & 97 & & & & 62.1 & 022 \\
\hline 1.113 & 067 & 009 & 0.004 & & & & 437 & & & 0.002 & & & & 117.4 & 617 \\
\hline 2.137 & 000 & & 0.004 & & & 13 & .839 & 3.473 & & 0.128 & & 0.000 & & 43.3 & 255 \\
\hline 566 & 66 & & & & & & & 9.524 & & & & & & 65.2 & 645 \\
\hline 70 & 02 & & 0.103 & & & & & 518 & & 02 & & & & .6 & 169 \\
\hline & 15 & & or & & & & 408 & & & 20 & & & & & 466 \\
\hline 0.314 & 001 & 262 & 0.050 & & & & & & & & & & & 8.0 & .097 \\
\hline & & & & & & & & & & & & & & & 661 \\
\hline ES & & & & & & & & & & & & & & 9.4 & 027 \\
\hline 88 & 068 & 31 & 005 & & & & & 754 & & & & & & 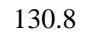 & 630 \\
\hline & 001 & & 0003 & & & & 299 & 0.534 & & & & & & & 292 \\
\hline 1.285 & 010 & & 0007 & & & & & 3733 & & & & & & & 756 \\
\hline & & & & & & & & & & & & & & & \\
\hline & & & & & & & & 59 & & & & & & 1.0 & 697 \\
\hline & & & & & & & & & & & & & & & \\
\hline & & & 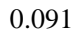 & & & & & & & & & & & & \\
\hline 0151 & 001 & & & & & & & & & & & & & & 108 \\
\hline & & & & & & & & & & & & & & & \\
\hline & & & & & & & & & & & & & & & 30 \\
\hline & & & & & & & & & & & & & & & \\
\hline & $0 r$ & & .106 & & & & & & & & & & & .9 & \\
\hline & & & & & & & & & & & & & & & \\
\hline & & & & & & & & & & & & & & & \\
\hline & & & & & & & & & & & & & & & \\
\hline & & & & & & & & & & & & & & & \\
\hline & & & & & & & & & & & & & & & 677 \\
\hline & & & & & & & & & & & & & & & \\
\hline & & & & & & & & & & & & & & & \\
\hline & & & & & & & & & & & & & & & \\
\hline & & & & & & & & & & & & & & & \\
\hline & & & & & & & & & & & & & & & 98 \\
\hline & & & & & & & & & & & & & & & \\
\hline & & & & & & & & & & & & & & & \\
\hline & & & & & & & & & & & & & & & \\
\hline & & & & & & & & & & & & & & 4.2 & 42 \\
\hline & & & & & & & & & & & & & & & \\
\hline & & & & & & & & & & & & & & & \\
\hline & & & & & & & & & & & & & & & \\
\hline & & & & & & & & & & & & & & & \\
\hline & & & & & & & & & & & & & & & 734 \\
\hline & & & & & & & & & & & & & & & \\
\hline & & & & & & & & & & & & & & & \\
\hline & & & & & & & & & & & & & & & \\
\hline & & & & & & & & & & & & & & & \\
\hline & & & & & & & & & & & & & & & 711 \\
\hline & & & & & & & & & & & & & & & \\
\hline & & & & & & & & & & & & & & & \\
\hline & & & & & & & & & & & & & & & \\
\hline & & & & & & & & & & & & & & 154.8 & \\
\hline & & & & & & & & & & & & & & .8 & 100 \\
\hline & & & & & & & & & & & & & & & \\
\hline & & & & & & & & & & & & & & & \\
\hline & & & & & & & & & & & & & & & \\
\hline & & & & & & & & & & & & & & 8.0 & \\
\hline & & & & & & & & & & & & & & 171.8 & 463 \\
\hline & & & & & & & & & & & & & & 0.7 & \\
\hline & & & & & & & & & & & & & & 74.3 & \\
\hline & 0.030 & 1.283 & 0.1 & 0.0212 & 0.0001 & 1.164 & 114 & 4.070 & 0.013 & $0.00 /$ & .020 & 0,001 & 0.0000 & 83.8 & \\
\hline
\end{tabular}


WSRC-TR-2002-00318, Rev. 0

\begin{tabular}{|c|c|c|c|c|c|c|c|c|c|c|c|c|c|c|c|}
\hline $\mathrm{Al}$ & $\mathrm{Cl}$ & $\mathrm{CO}_{3}$ & $\mathrm{C}_{2} \mathrm{O}_{4}$ & $F$ & $\mathrm{Fe}$ & $\mathrm{NO}_{2}$ & $\mathrm{NO}_{3}$ & $\mathrm{OH}$ & $\mathrm{K}$ & $\mathrm{PO}_{4}$ & $\mathrm{SO}_{4}$ & $\overline{\mathrm{Si}}$ & $\bar{U}$ & $\mathrm{~T}\left({ }^{\circ} \mathrm{C}\right)$ & Evap \\
\hline 022 & 004 & 275 & .044 & 0028 & 0000 & 295 & .910 & 9.909 & 164 & .036 & & 001 & 0020 & 114.1 & 0.581 \\
\hline & & & & & & & & & & & & & & & 269 \\
\hline & 02 & & 067 & & & & & & & & & & & & 480 \\
\hline .013 & & & 001 & & & 000 & & & & & & & & & 114 \\
\hline & & & 004 & & & .445 & & & & & & & & 137.1 & .533 \\
\hline & & & 2 & & & & & & & & & & & & 009 \\
\hline & & & .008 & & & 562 & & & & & & & & & 678 \\
\hline 14 & 07 & 771 & 0.041 & & & & & & & & 460 & & & 52.9 & .039 \\
\hline & 001 & 477 & 0.014 & & & 485 & 461 & & & 0.028 & & & & & .419 \\
\hline & & & 0.011 & & & 2.527 & & & & & & & & 53.1 & .284 \\
\hline & & & 0.049 & & & 473 & & & & & & & & & 684 \\
\hline & & & 001 & & & 861 & & & & & & & & .8 & 252 \\
\hline & 01 & & .001 & & & 667 & & 1.924 & & 07 & & & & 27.2 & 786 \\
\hline & & 094 & 0.006 & & & 382 & & & & 0.028 & 102 & & & 93.3 & .038 \\
\hline & & & & & & & & & & & & & & & 513 \\
\hline & & 50 & 01 & & & 237 & & & & & & & & 3 & 133 \\
\hline & & & 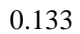 & & & & & & & & & & & & \\
\hline & & & & & & & & & & & & & & 0.2 & \\
\hline & & 030 & 100 & & & & & & & & & & & 6.2 & 525 \\
\hline & & & & & & & & & & & & & & & 213 \\
\hline & & & 0.001 & & & & & & & & & & & 9.0 & 622 \\
\hline & & & 0.004 & & & & & & & & & & & & \\
\hline & 000 & & 007 & & & 78 & & & & & & & & & \\
\hline & & & & & & & & & & & & & & & 161 \\
\hline & & & & & & & & & & & & & & & \\
\hline & & & 14 & & & & & & & & & & & & 223 \\
\hline & & & 0.017 & & & & & & & & & & & & \\
\hline 0065 & 117 & 327 & 0.000 & & & 157 & & 2.758 & & & & & & & .064 \\
\hline & & & & & & & & & & & & & & & \\
\hline & & & & & & & & & & & & & & & \\
\hline & & & 3 & & & & & & & & & & & 54.0 & 20 \\
\hline & & & & & & & & & & & & & & & \\
\hline 086 & (000 & & 0 & & & & & & & & & & & & .770 \\
\hline & & & & & & & & & & & & & & & \\
\hline & & & & & & & & & & & & & & & \\
\hline & & & & & & & & & & & & & & & \\
\hline & & & & & & & & & & & & & & & \\
\hline & & & & & & & & & & & & & & & 380 \\
\hline & & & & & & & & & & & & & & & \\
\hline & & & & & & & & & & & & & & 9 & \\
\hline & & & & & & & & & & & & & & & \\
\hline & & & & & & & & & & & & & & .6 & \\
\hline & & & & & & & & & & & & & & & 430 \\
\hline & & & & & & & & & & & & & & & \\
\hline & & & & & & & & & & & & & & & \\
\hline & & & & & & & & & & & & & & & \\
\hline & & & & & & & & & & & & & & & \\
\hline & & & & & & & & & & & & & & & \\
\hline & & & & & & & & & & & & & & & \\
\hline & & & & & & & & & & & & & & & \\
\hline & & & & & & & & & & & & & & .6 & \\
\hline & & & & & & & & & & & & & & & \\
\hline & & & & & & & & & & & & & & & \\
\hline & & & & & & & & & & & & & & & \\
\hline & & & & & & & & & & & & & & & \\
\hline & & & & & & & & & & & & & & & 67 \\
\hline & & & & & & & & & & & & & & & \\
\hline & & & & & & & & & & & & & & & \\
\hline & & & & & & & & & & & & & & & \\
\hline & & & & & & & & & & & & & & & \\
\hline & & & & & & & & & & & & & & 99.1 & 753 \\
\hline & & & & & & & & & & & & & & & 061 \\
\hline & & & & & & & & & & & & & & & \\
\hline & & & & & & & & & & & & & & & \\
\hline & & & & & & & & & & & & & & & \\
\hline & & & & & & & & & & & & & & 133.0 & 280 \\
\hline & & & & & & & & & & & & & & 6.1 & 609 \\
\hline & & & & & & & & & & & & & & 160.0 & 270 \\
\hline & & & & & & & & & & & & & & 0 & \\
\hline & & & & & & & & & 0.149 & 0.030 & 0.001 & 0.037 & 00 & 178.4 & 0.323 \\
\hline
\end{tabular}


WSRC-TR-2002-00318, Rev. 0

\begin{tabular}{|c|c|c|c|c|c|c|c|c|c|c|c|c|c|c|c|}
\hline $\mathrm{Al}$ & $\mathrm{Cl}$ & $\mathrm{CO}_{3}$ & $\mathrm{C}_{2} \mathrm{O}_{4}$ & $\mathrm{~F}$ & $\mathrm{Fe}$ & $\mathrm{NO}_{2}$ & $\mathrm{NO}_{3}$ & $\mathrm{OH}$ & $\mathrm{K}$ & $\mathrm{PO}_{4}$ & $\mathrm{SO}_{4}$ & $\overline{\mathrm{Si}}$ & U & $\mathrm{T}\left({ }^{\circ} \mathrm{C}\right)$ & Evap \\
\hline 0.061 & 003 & 047 & 001 & 1801 & 000 & 417 & 120 & 627 & 14 & & .421 & 02 & .0030 & 61.3 & .644 \\
\hline & & & & & & & & & & & & & & & \\
\hline & & & & & & & & & & & & & & & 647 \\
\hline 42 & 035 & & 014 & 002 & & & 060 & & & & & 14 & & 30.2 & .075 \\
\hline & 002 & & 045 & & & & 026 & 2.254 & & & & & & 60.2 & .747 \\
\hline חרקח & 008 & & .002 & & & 775 & & 1267 & & & & & & & .256 \\
\hline & & & & & & & & & & & & & & & \\
\hline & 039 & & 0.002 & & & 466 & & 0.799 & & & & & & 173.4 & 305 \\
\hline 016 & 000 & 019 & 0.001 & 000 & 02 & 223 & .094 & 4.701 & 014 & .004 & 019 & .000 & & 90.3 & 633 \\
\hline 0.006 & 031 & & 0.037 & & & .190 & 067 & 1.129 & & 0.003 & .001 & 0.000 & & 156.8 & .070 \\
\hline & 00 & & 0 & & & & 208 & .322 & & 131 & & & & 96.9 & 434 \\
\hline & & & ב707 & & & 528 & 75 & & & 01 & & & & & 230 \\
\hline & 002 & & 0.099 & & & 222 & 057 & & & & & & & 88.1 & 664 \\
\hline & 053 & & 0.001 & & & & & & & & & & & 142.8 & 361 \\
\hline & 000 & & & & & & 20 & & & 0.007 & 778 & 0.009 & & 71.2 & .566 \\
\hline & 2. & & & & & & & & & & & & & & 231 \\
\hline & 04 & & 0.00 & & & & & 160 & & 01 & & & & & 534 \\
\hline & & & 02 & & & & & & & 01 & & & & & 392 \\
\hline & 000 & & 0.022 & & & & & & & & & & & 97.4 & 620 \\
\hline & & & & & & & & & & & & & & 140.9 & 397 \\
\hline & & & & & & & & & & & & & & & 752 \\
\hline & & & & & & & & & & & & & & & \\
\hline & ( & & & & & & & & & & & & & 8 & \\
\hline & 027 & & 0001 & & & & & & & & & & & & 311 \\
\hline & & & & & & & & & & & & & & & 552 \\
\hline & & & & & & & & & & & & & & & 184 \\
\hline & & & & & & & & & & & & & & & 44 \\
\hline 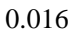 & & & 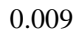 & & & & & & & & & & & & \\
\hline & 001 & & & & & & & & & & & & & 98.2 & .792 \\
\hline & & & & & & & & & & & & & & & \\
\hline & & & & & & & & & & & & & & & 573 \\
\hline & & & & & & & & & & & & & & & \\
\hline 24 & - & & .009 & & & & & & & & & & & .4 & \\
\hline & & & & & & & & & & & & & & & 028 \\
\hline & & & & & & & & & & & & & & & \\
\hline & & & & & & & & & & & & & & & 20 \\
\hline & & & & & & & & & & & & & & & \\
\hline & & & & & & & & & & & & & & & 131 \\
\hline & & & & & & & & & & & & & & & \\
\hline & & & & & & & & & & & & & & & \\
\hline & & & & & & & & & & & & & & & \\
\hline & & & & & & & & & & & & & & & \\
\hline & & & & & & & & & & & & & & & 95 \\
\hline & & & & & & & & & & & & & & & \\
\hline & & & & & & & & & & & & & & & \\
\hline & & & & & & & & & & & & & & & \\
\hline & & & & & & & & & & & & & & & 02 \\
\hline & & & & & & & & & & & & & & & \\
\hline & & & & & & & & & & & & & & & \\
\hline & & & & & & & & & & & & & & 4 & \\
\hline & & & & & & & & & & & & & & & \\
\hline & & & & & & & & & & & & & & 9.9 & 731 \\
\hline & & & & & & & & & & & & & & & \\
\hline & & & & & & & & & & & & & & & \\
\hline & & & & & & & & & & & & & & .2 & \\
\hline & & & & & & & & & & & & & & & \\
\hline & & & & & & & & & & & & & & 129.1 & 319 \\
\hline & & & & & & & & & & & & & & & 17 \\
\hline & & & & & & & & & & & & & & & \\
\hline & & & & & & & & & & & & & & & \\
\hline & & & & & & & & & & & & & & & \\
\hline & & & & & & & & & & & & & & 9.5 & 688 \\
\hline & & & & & & & & & & & & & & & \\
\hline & & & & & & & & & & & & & & & \\
\hline & & & & & & & & & & & & & & & \\
\hline & & & & & & & & & & & & & & 3.8 & 773 \\
\hline & & & & & & & & & & & & & & 148.0 & 358 \\
\hline & & & & & & & & & & & & & & & \\
\hline & & & & & & & & & & & & & & 52.9 & \\
\hline & 0.107 & & & & 0.0000 & 1.428 & 24 & & & 0.120 & .517 & 0.003 & 0.000 & 9.5 & \\
\hline
\end{tabular}


WSRC-TR-2002-00318, Rev. 0

\begin{tabular}{|c|c|c|c|c|c|c|c|c|c|c|c|c|c|c|c|}
\hline $\mathrm{Al}$ & $\mathrm{Cl}$ & $\mathrm{O}_{3}$ & $\mathrm{C}_{2} \mathrm{O}_{4}$ & F & $\mathrm{Fe}$ & $\mathrm{NO}_{2}$ & $\mathrm{NO}_{3}$ & $\mathrm{OH}$ & K & $\mathrm{PO}_{4}$ & $\mathrm{SO}_{4}$ & $\mathrm{Si}$ & $\mathrm{U}$ & $\mathrm{T}\left({ }^{\circ} \mathrm{C}\right)$ & Evap \\
\hline 0.006 & 001 & 134 & 004 & 0002 & 00 & 856 & 1.249 & .148 & 360 & & .001 & 00 & 081 & 121.5 & 369 \\
\hline & & & & & & & & & & & & & & & 469 \\
\hline & & & & & & & & & & & & & & & 181 \\
\hline 15 & 009 & & 09 & & & 413 & & & & & & 00 & & 44.6 & .575 \\
\hline 0.076 & 001 & & .055 & & & 112 & .712 & & & & & 0.002 & & 150.2 & .281 \\
\hline 0.016 & 013 & & .042 & & & 099 & 728 & & & & & & & 91.1 & .789 \\
\hline & 01 & & 0 & & & & & & & & & & & & \\
\hline & 029 & & 0.004 & & & 168 & 699 & & & & & & & 50.1 & 744 \\
\hline 0.022 & 001 & 941 & 0.001 & 0120 & & 406 & 987 & 105 & 156 & 0.002 & 039 & .009 & 000 & 162.0 & 166 \\
\hline 0.016 & 005 & & 0.005 & & & 674 & .219 & & 424 & 0.024 & 001 & 0.001 & & 03.4 & .783 \\
\hline & 01 & & 00 & & & 113 & 034 & & & 01 & & & & 45.5 & 316 \\
\hline & 09 & & 085 & & & 174 & 67 & 157 & & 04 & & & & & 542 \\
\hline & 001 & & .104 & & & 097 & & & & 22 & & & & 57.4 & 164 \\
\hline & 018 & & 0.064 & & & 372 & & & & & & & & 97.7 & 694 \\
\hline & 001 & & & & & & 921 & & & 0.017 & & & & 117.1 & .000 \\
\hline & & & 003 & & & & & & & & & & & .2 & 492 \\
\hline & 00 & & 002 & & & & & & & & & & & 79.2 & 003 \\
\hline & & & 005 & & & & & & & & & & & 87.6 & 506 \\
\hline & 000 & & 0.002 & & & 142 & 072 & & & & & & & & 314 \\
\hline & & & & & & & & & & & & & & & 450 \\
\hline & & & & & & & & & & & & & & & 341 \\
\hline & & & & & & & & & & & & & & & \\
\hline & 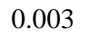 & & & & & & & & & & & & & & \\
\hline 0.012 & 058 & & 0005 & & & & & & & & & & & & \\
\hline & & & & & & & & & & & & & & & 95 \\
\hline & & & & & & & & & & & & & & & 683 \\
\hline & & & & & & & & & & & & & & & 06 \\
\hline & na & & 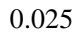 & & & & & & & & & & & 80.7 & \\
\hline & O०1 & & 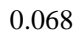 & & & & & & & & & & & & \\
\hline & & & & & & & & & & & & & & & \\
\hline & & & & & & & & & & & & & & .6 & 52 \\
\hline & & & & & & & & & & & & & & & \\
\hline & רח & & .001 & & & & & & & & & & & 1.3 & \\
\hline & & & & & & & & & & & & & & 50.9 & \\
\hline & & & & & & & & & & & & & & & \\
\hline & & & & & & & & & & & & & & & \\
\hline & & & & & & & & & & & & & & & \\
\hline & & & & & & & & & & & & & & 7.0 & 611 \\
\hline & & & & & & & & & & & & & & & \\
\hline & & & & & & & & & & & & & & & \\
\hline & & & & & & & & & & & & & & & \\
\hline & & & & & & & & & & & & & & & \\
\hline & & & & & & & & & & & & & & .3 & \\
\hline & & & & & & & & & & & & & & & \\
\hline & & & & & & & & & & & & & & & \\
\hline & & & & & & & & & & & & & & & \\
\hline & & & & & & & & & & & & & & 42.7 & 16 \\
\hline & & & & & & & & & & & & & & & \\
\hline & & & & & & & & & & & & & & & \\
\hline & & & & & & & & & & & & & & & \\
\hline & & & & & & & & & & & & & & & \\
\hline & & & & & & & & & & & & & & & 706 \\
\hline & & & & & & & & & & & & & & & \\
\hline & & & & & & & & & & & & & & & \\
\hline & & & & & & & & & & & & & & 78 & \\
\hline & & & & & & & & & & & & & & & \\
\hline & & & & & & & & & & & & & & 3.5 & 264 \\
\hline & & & & & & & & & & & & & & & \\
\hline & & & & & & & & & & & & & & & \\
\hline & & & & & & & & & & & & & & & \\
\hline & & & & & & & & & & & & & & & \\
\hline & & & & & & & & & & & & & & 176.7 & 545 \\
\hline & & & & & & & & & & & & & & & \\
\hline & & & & & & & & & & & & & & & \\
\hline & & & & & & & & & & & & & & & \\
\hline & & & & & & & & & & & & & & 122.0 & 03 \\
\hline & & & & & & & & & & & & & & 71.7 & 139 \\
\hline & & & & & & & & & & & & & & 40.6 & \\
\hline & & & & & & & & & & & & & & 9.2 & \\
\hline & 0.040 & 0.0 & & 100 & 108 & 0.445 & & 0.300 & .152 & 0.005 & .001 & 0.00 & 0.0003 & 78.1 & \\
\hline
\end{tabular}


WSRC-TR-2002-00318, Rev. 0

\begin{tabular}{|c|c|c|c|c|c|c|c|c|c|c|c|c|c|c|c|}
\hline $\mathrm{Al}$ & $\mathrm{Cl}$ & $\mathrm{CO}_{3}$ & $\mathrm{C}_{2} \mathrm{O}_{4}$ & $\mathrm{~F}$ & $\mathrm{Fe}$ & $\mathrm{NO}_{2}$ & $\mathrm{NO}_{3}$ & $\mathrm{OH}$ & $\mathrm{K}$ & $\mathrm{PO}_{4}$ & $\mathrm{SO}_{4}$ & $\mathrm{Si}$ & $\overline{\mathrm{U}}$ & $\mathrm{T}\left({ }^{\circ} \mathrm{C}\right)$ & Evap \\
\hline 0.016 & 001 & 009 & 011 & 016 & 392 & 51 & 14 & & 519 & 40 & 103 & 057 & 0000 & 105.1 & .044 \\
\hline & & & & & & & & & & & & & & & 747 \\
\hline & & & & & & & & & & & & & & & \\
\hline & & & & & & & & & & & & & & & \\
\hline & & & & & & & & & & & & & & & 97 \\
\hline & & & & & & & & & & & & & & & 692 \\
\hline & & & & & & & & & & & & & & 68.7 & 072 \\
\hline & & & & & & & & & & & & & & & 470 \\
\hline & & & & & & & & & & & & & & & \\
\hline & & & & & & & & & & & & & & & \\
\hline & & & & & & & & & & & & & & 40.5 & 005 \\
\hline & & & & & & & & & & & & & & & \\
\hline & & & & & & & & & & & & & & & \\
\hline & & & & & & & & & & & & & & & 102 \\
\hline 0. & & & 53 & & & & & & & & & & & 99.6 & 123 \\
\hline & & & & & & & & & & & & & & & 663 \\
\hline & & & & & & & & & & & & & & & \\
\hline & & & & & & & & & & & & & & & \\
\hline & & & J & & & & & & & & & & & & 394 \\
\hline & & & 002 & & & & & & & & & & & 159.5 & 702 \\
\hline & & & & & & & & & & & & & & & 186 \\
\hline & & & & & & & & & & & & & & & \\
\hline & & & & & & & & & & & & & & 55.3 & 95 \\
\hline & & & & & & & & & & & & & & 165.8 & .758 \\
\hline & & & & & & & & & & & & & & 6.5 & 277 \\
\hline & & & & & & & & & & & & & & & \\
\hline & & & & & & & & & & & & & & & \\
\hline & & & & & & & & & & & & & & 3.9 & \\
\hline 0.019 & 0.003 & 0.014 & 0.001 & 0.0001 & 0.0000 & 0.282 & 0.231 & 0.113 & 0.002 & 0.001 & 0.010 & 0.001 & 0.0000 & 75.0 & 0.066 \\
\hline
\end{tabular}


WSRC-TR-2002-00318, Rev. 0

Table XII. GWB Results Corresponding to the Optimized Design Matrix

\begin{tabular}{|c|c|c|c|c|c|c|c|c|c|c|c|}
\hline \multicolumn{4}{|c|}{$\log _{10}(\mathrm{Q} / \mathrm{K})$} & \multicolumn{4}{|c|}{$\log _{10}(\mathrm{Q} / \mathrm{K})$} & \multicolumn{4}{|c|}{$\log _{10}(\mathrm{Q} / \mathrm{K})$} \\
\hline FileNo & NAS & Zeolite & $\mathrm{K}_{\mathrm{st}}$ & FileNo & NAS & Zeolite & $\mathrm{K}_{\mathrm{sp}}$ & FileNo & NAS & Zeolite & $\mathrm{K}_{\mathrm{sp}}$ \\
\hline 1 & 30.589 & 26.957 & -19.241 & 172 & -16.189 & -6.984 & -58.45 & 343 & -38.783 & -26.028 & -71.128 \\
\hline 2 & -0.711 & 6.711 & -47.52 & 173 & 32.232 & 33.73 & -15.498 & 344 & 14.241 & 10.894 & -32.178 \\
\hline 3 & 15.483 & 18.026 & -33.575 & 174 & -21.337 & -0.888 & -47.042 & 345 & -24.863 & -9.104 & -56.762 \\
\hline 4 & -4.662 & 11.13 & -55.107 & 175 & 41.743 & 40.151 & -9.982 & 346 & 4.563 & 0.667 & -46.094 \\
\hline 5 & 23.067 & 19.315 & -34.759 & 176 & -20.968 & -4.202 & -57.058 & 347 & -35.487 & -26.85 & -66.36 \\
\hline 6 & 20.061 & 26.467 & -39.875 & 177 & 2.505 & 8.365 & -38.846 & 348 & -8.63 & -6.446 & -45.277 \\
\hline 7 & 44.327 & 42.461 & -13.108 & 178 & -4.563 & 11.746 & -36.38 & 349 & -37.1 & -20.377 & -71.864 \\
\hline 8 & 0.885 & 12.316 & -52.273 & 179 & -19.007 & -16.01 & -62.454 & 350 & 9.463 & 8.223 & -35.752 \\
\hline 9 & 39.38 & 32.252 & -8.296 & 180 & 3.132 & 14.681 & -33.347 & 351 & -44.804 & -23.724 & -74.094 \\
\hline 10 & 21.726 & 30.807 & -30.396 & 181 & -18.656 & -10.583 & -59.712 & 352 & 7.401 & 3.357 & -36.822 \\
\hline 11 & 48.681 & 45.425 & -1.082 & 182 & 9.37 & 15.026 & -27.981 & 353 & -52.309 & -38.363 & -85.506 \\
\hline 12 & 12.524 & 20.987 & -39.256 & 183 & -25.729 & -22.013 & -59.644 & 354 & -41.459 & -38.189 & -86.473 \\
\hline 13 & 63.575 & 57.605 & -1.807 & 184 & 0.645 & 13.918 & -29.824 & 355 & -26.258 & -17.12 & -52.009 \\
\hline 14 & -6.197 & 8.862 & -53.273 & 185 & -30.587 & -24.334 & -68.912 & 356 & -40.087 & -35.067 & -68.714 \\
\hline 15 & 28.347 & 23.713 & -29.103 & 186 & 22.363 & 30.652 & -17.776 & 357 & -25.368 & -16.328 & -59.347 \\
\hline 16 & -7.452 & 8.982 & -53.318 & 187 & -6.988 & -4.853 & -53.429 & 358 & -55.687 & -49.405 & -87.097 \\
\hline 17 & -8.841 & -7.815 & -61.572 & 188 & -11.273 & -1.162 & -39.561 & 359 & -17.878 & -6.499 & -52.327 \\
\hline 18 & 15.199 & 18.812 & -31.439 & 189 & -21.404 & -18.579 & -60.016 & 360 & -34.565 & -31.631 & -74.632 \\
\hline 19 & 0.595 & 2.171 & -48.024 & 190 & 5.809 & 21.156 & -26.4 & 361 & -18.777 & -12.445 & -44.165 \\
\hline 20 & 29.295 & 37.578 & -13.977 & 191 & -1.486 & 0.384 & -55.58 & 362 & -57.59 & -51.38 & -89.918 \\
\hline 21 & 23.079 & 22.792 & -27.45 & 192 & 6.281 & 19.96 & -32.622 & 363 & -43.37 & -32.422 & -68.125 \\
\hline 22 & 18.873 & 26.435 & -22.726 & 193 & -7.094 & 3.443 & -39.014 & 364 & -21.789 & -19.228 & -59.926 \\
\hline 23 & 8.086 & 10.873 & -42.091 & 194 & -12.853 & -11.322 & -52.495 & 365 & -9.038 & 0.997 & -34.858 \\
\hline 24 & 8.734 & 19.55 & -31.971 & 195 & 1.814 & 9.043 & -39.431 & 366 & -15.349 & -14.358 & -58.792 \\
\hline 25 & 22.601 & 19.71 & -31.136 & 196 & -12.531 & -8.342 & -49.132 & 367 & -9.167 & 1.708 & -39.615 \\
\hline 26 & 19.342 & 27.48 & -24.722 & 197 & -9.25 & -0.68 & -41.007 & 368 & -43.654 & -39.323 & -80.553 \\
\hline 27 & 30.482 & 28.039 & -25.369 & 198 & -14.102 & -10.412 & -46.642 & 369 & -31.884 & -15.097 & -54.89 \\
\hline 28 & 35.981 & 47.302 & -6.922 & 199 & -1.306 & 15.122 & -27.778 & 370 & 4.228 & 2.743 & -42.651 \\
\hline 29 & 34.038 & 31.3 & -30.667 & 200 & -17.148 & -10.512 & -62.881 & 371 & -53.24 & -32.941 & -85.88 \\
\hline 30 & 40.681 & 41.209 & -26.448 & 201 & -7.087 & 4.918 & -37.059 & 372 & -19.271 & -16.141 & -55.666 \\
\hline 31 & -3.318 & -1.253 & -48.03 & 202 & -34.031 & -28.934 & -66.157 & 373 & -57.549 & -44.356 & -84.492 \\
\hline 32 & 40.029 & 46.823 & -11.021 & 203 & 25.254 & 36.913 & -16.962 & 374 & -12.734 & -11.816 & -44.675 \\
\hline 33 & 33.454 & 28.841 & -22.225 & 204 & -8.511 & -7.143 & -59.706 & 375 & -45.48 & -25.724 & -75.991 \\
\hline 34 & 6.238 & 10.651 & -39.883 & 205 & 10.163 & 24.13 & -20.44 & 376 & -5.99 & -4.025 & -38.208 \\
\hline 35 & 37.67 & 36.187 & -18.17 & 206 & 6.318 & 9.918 & -38.709 & 377 & -55.963 & -37.06 & -79.427 \\
\hline 36 & -9.15 & 4.467 & -55.428 & 207 & 31.534 & 39.523 & -19.099 & 378 & -5.486 & -5.04 & -38.433 \\
\hline 37 & 45.758 & 45.434 & -13.53 & 208 & 9.78 & 14.234 & -44.676 & 379 & -41.871 & -28.933 & -71.635 \\
\hline 38 & 34.998 & 41.297 & -38.338 & 209 & -9.379 & -1.864 & -53.281 & 380 & -27.212 & -25.697 & -55.802 \\
\hline 39 & 36.653 & 35.246 & -17.878 & 210 & 6.959 & 6.41 & -39.118 & 381 & -40.842 & -31.152 & -75.024 \\
\hline 40 & -5.119 & 4.952 & -50.945 & 211 & -48.712 & -32.828 & -76.739 & 382 & -15.472 & -13.154 & -48.526 \\
\hline 41 & 35.615 & 35.026 & -11.272 & 212 & 11.963 & 11.356 & -36.904 & 383 & -26.967 & -12.809 & -66.319 \\
\hline 42 & -4.309 & 8.786 & -50.567 & 213 & -50.303 & -29.081 & -73.296 & 384 & -28.592 & -26.988 & -58.232 \\
\hline 43 & 43.005 & 43.562 & -6.92 & 214 & 3.41 & 3.66 & -29.972 & 385 & -28.236 & -18.595 & -63.327 \\
\hline 44 & 4.015 & 21.386 & -49.01 & 215 & -45.399 & -27.351 & -74.348 & 386 & 10.403 & 14.337 & -40.19 \\
\hline 45 & 43.142 & 41.356 & -26.824 & 216 & 9.866 & 12.377 & -32.747 & 387 & 17.356 & 16.881 & -34.088 \\
\hline 46 & 26.608 & 36.426 & -32.319 & 217 & -5.071 & 10.211 & -43.303 & 388 & 10.314 & 19.492 & -57.248 \\
\hline 47 & 17.148 & 18.263 & -34.004 & 218 & 2.276 & 7.534 & -27.991 & 389 & 15.287 & 11.355 & -34.414 \\
\hline 48 & -10.332 & 2.962 & -54.369 & 219 & -21.903 & -1.178 & -57.379 & 390 & -7.516 & 6.295 & -52.909 \\
\hline 49 & 5.549 & 4.562 & -47.498 & 220 & 28.234 & 26.692 & -11.436 & 391 & -1.946 & -1.502 & -52.562 \\
\hline 50 & 19.064 & 27.598 & -31.893 & 221 & -4.84 & 7.786 & -46.48 & 392 & -32.845 & -23.948 & -76.553 \\
\hline 51 & 10.054 & 12.238 & -33.492 & 222 & 5.986 & 10.014 & -23.558 & 393 & 15.88 & 13.159 & -37.912 \\
\hline 52 & 34.685 & 46.142 & -11.091 & 223 & -14.051 & -5.34 & -51.732 & 394 & -12.727 & 2.618 & -65.132 \\
\hline 53 & -2.966 & 0.875 & -54.971 & 224 & 9.319 & 9.821 & -33.905 & 395 & 13.948 & 10.16 & -29.951 \\
\hline 54 & 18.946 & 25.901 & -30.511 & 225 & 2.123 & 14.17 & -35.457 & 396 & -34.039 & -19.135 & -79.195 \\
\hline 55 & 19.381 & 19.277 & -38.648 & 226 & -12.971 & -8.744 & -61.335 & 397 & 4.966 & 2.878 & -48.884 \\
\hline 56 & 47.569 & 56.421 & -3.003 & 227 & 14.964 & 29.959 & -31.885 & 398 & -26.878 & -14.046 & -80.566 \\
\hline 57 & -5.953 & -6.588 & -60.109 & 228 & -20.707 & -11.681 & -60.542 & 399 & 28.793 & 24.426 & -18.126 \\
\hline 58 & 36.866 & 40.931 & -16.453 & 229 & 0.855 & 16.009 & -31.886 & 400 & -19.525 & -3.389 & -69.06 \\
\hline 59 & 13.248 & 13.02 & -38.997 & 230 & -33.641 & -27.261 & -65.918 & 401 & 24.221 & 22.614 & -23.836 \\
\hline 60 & 24.374 & 31.951 & -24.154 & 231 & 17.088 & 30.756 & -23.743 & 402 & 21.713 & 30.43 & -28.81 \\
\hline 61 & 30.117 & 27.48 & -36.695 & 232 & -11.932 & -5.965 & -53.32 & 403 & -9.168 & -4.335 & -66.316 \\
\hline 62 & 26.511 & 33.074 & -17.517 & 233 & 12.117 & 19.415 & -29.031 & 404 & 35.393 & 44.517 & -34.552 \\
\hline 63 & -4.489 & 0.506 & -59.483 & 234 & -0.284 & 1.915 & -44.52 & 405 & -22.505 & -15.493 & -73.133 \\
\hline 64 & 35.588 & 43.538 & -7.356 & 235 & 4.621 & 17.26 & -25.815 & 406 & 13.742 & 18.616 & -33.724 \\
\hline 65 & 23.901 & 26.09 & -22.224 & 236 & -17.494 & -12.661 & -59 & 407 & -19.252 & -15.373 & -70.207 \\
\hline 66 & -4.949 & -5.844 & -63.595 & 237 & -4.731 & 3.466 & -35.128 & 408 & 0.318 & 3.634 & -52.287 \\
\hline
\end{tabular}


WSRC-TR-2002-00318, Rev. 0

\begin{tabular}{|c|c|c|c|c|c|c|c|c|c|c|c|}
\hline \multicolumn{4}{|c|}{$\log _{10}(\mathrm{Q} / \mathrm{K})$} & \multicolumn{4}{|c|}{$\log _{10}(\mathrm{Q} / \mathrm{K})$} & \multicolumn{4}{|c|}{$\log _{10}(\mathrm{Q} / \mathrm{K})$} \\
\hline FileNo & NAS & Zeolite & $\mathrm{K}_{\mathrm{sp}}$ & FileNo & NAS & Zeolite & $\mathrm{K}_{\mathrm{sp}}$ & FileNo & NAS & Zeolite & $\mathrm{K}_{\mathrm{sp}}$ \\
\hline 67 & 20.141 & 23.845 & -26.612 & 238 & 2.967 & 2.901 & -41.62 & 409 & -8.256 & -7.055 & -64.768 \\
\hline 68 & 16.042 & 14.412 & -39.114 & 239 & -8.43 & 1.025 & -42.546 & 410 & 11.397 & 22.476 & -36.517 \\
\hline 69 & 37.233 & 43.276 & -10.99 & 240 & 0.051 & 4.572 & -50.209 & 411 & -12.895 & -10.984 & -68.174 \\
\hline 70 & 6.379 & 5.501 & -54.765 & 241 & -3.668 & 4.534 & -47.737 & 412 & 32.178 & 35.542 & -38.811 \\
\hline 71 & 10.313 & 23.901 & -37.791 & 242 & 25.47 & 26.835 & -18.024 & 413 & 5.234 & 1.921 & -52.685 \\
\hline 72 & -1.914 & -0.643 & -52.154 & 243 & -9.241 & 0.613 & -52.755 & 414 & 1.146 & 11.652 & -42.138 \\
\hline 73 & 41.27 & 52.393 & -11.612 & 244 & 21.248 & 23.193 & -20.038 & 415 & -36.569 & -30.394 & -87.085 \\
\hline 74 & 17.958 & 20.08 & -37.156 & 245 & -24.933 & -14.679 & -56.044 & 416 & -0.814 & 9.297 & -47.208 \\
\hline 75 & 34.475 & 41.904 & -11.198 & 246 & -1.237 & 4.841 & -32.523 & 417 & 4.126 & 2.838 & -56.247 \\
\hline 76 & 14.66 & 13.414 & -32.761 & 247 & -45.618 & -24.611 & -73.147 & 418 & -19.583 & -3.922 & -72.121 \\
\hline 77 & 15.06 & 27.219 & -29.182 & 248 & 19.259 & 18.198 & -31.327 & 419 & 8.248 & 6.263 & -41.074 \\
\hline 78 & -8.861 & -3.899 & -56.051 & 249 & 9.082 & 17.112 & -39.785 & 420 & -35.289 & -25.351 & -81.233 \\
\hline 79 & 55.876 & 59.148 & -2.98 & 250 & 5.988 & 5.765 & -27.446 & 421 & 10.916 & 6.97 & -44.872 \\
\hline 80 & 14.557 & 16.767 & -44.559 & 251 & -12.481 & 6.881 & -56.707 & 422 & -11.697 & 3.273 & -56.05 \\
\hline 81 & 1.024 & 16.359 & -43.042 & 252 & 37.031 & 33.234 & -13.221 & 423 & 9.786 & 6.646 & -42.576 \\
\hline 82 & 16.759 & 14.053 & -31.807 & 253 & -27.415 & -7.401 & -65.464 & 424 & -4.529 & -0.326 & -55.78 \\
\hline 83 & 13.762 & 23.998 & -40.276 & 254 & 11.143 & 13.049 & -32.617 & 425 & 27.931 & 24.201 & -30.223 \\
\hline 84 & 18.516 & 18.412 & -28.607 & 255 & -27.494 & -12.245 & -60.915 & 426 & -24.278 & -9.334 & -79.66 \\
\hline 85 & 3.83 & 17.738 & -49.673 & 256 & 13.576 & 13.87 & -33.121 & 427 & 20.036 & 15.336 & -32.569 \\
\hline 86 & 44.088 & 40.138 & -20.345 & 257 & -3.323 & 0.843 & -45.736 & 428 & -2.466 & 3.014 & -60.132 \\
\hline 87 & -13.72 & 3.724 & -59.295 & 258 & -34.83 & -20.009 & -72.231 & 429 & 23.169 & 21.421 & -33.022 \\
\hline 88 & 13.743 & 11.47 & -34.711 & 259 & 7.041 & 8.001 & -43.953 & 430 & -29.724 & -22.277 & -75.975 \\
\hline 89 & -0.821 & 16.608 & -45.379 & 260 & -17.988 & -10.646 & -57.898 & 431 & -0.171 & -2.724 & -44.43 \\
\hline 90 & 33.467 & 34.743 & -25.112 & 261 & 6.042 & 3.736 & -36.366 & 432 & -44.371 & -32.942 & -81.49 \\
\hline 91 & 1.434 & 9.985 & -46.196 & 262 & -20.778 & -7.918 & -56.713 & 433 & 14.771 & 9.757 & -34.415 \\
\hline 92 & 32.187 & 29.547 & -19.609 & 263 & -10.849 & -8.159 & -51.597 & 434 & 4.907 & 7.513 & -52.627 \\
\hline 93 & -1.179 & 8.511 & -55.721 & 264 & -36.826 & -25.235 & -78.365 & 435 & 0.51 & -2.086 & -55.092 \\
\hline 94 & 42.88 & 36.777 & -17.378 & 265 & -8.961 & -8.107 & -39.199 & 436 & 39.487 & 46.118 & -29.019 \\
\hline 95 & -6.976 & 10.47 & -54.65 & 266 & -45.987 & -25.178 & -83.177 & 437 & 4.246 & 2.485 & -58.125 \\
\hline 96 & 49.187 & 45.774 & -5.967 & 267 & -15.636 & -14.222 & -61.076 & 438 & 11.395 & 13.662 & -31.761 \\
\hline 97 & 45.399 & 54.732 & -5 & 268 & -59.453 & -44.287 & -90.39 & 439 & -11.275 & -8.024 & -63.491 \\
\hline 98 & 17.683 & 19.423 & -39.464 & 269 & -8.727 & -8.107 & -52.217 & 440 & 12.46 & 22.976 & -31.829 \\
\hline 99 & 17.983 & 27.991 & -22.758 & 270 & -63.263 & -46.093 & -89.665 & 441 & -0.103 & -1.651 & -61.648 \\
\hline 100 & 22.183 & 24.103 & -32.125 & 271 & 9.789 & 6.884 & -38.2 & 442 & 21.804 & 26.869 & -22.56 \\
\hline 101 & 69.009 & 72.399 & -4.375 & 272 & -30.979 & -13.175 & -62.369 & 443 & -21.417 & -19.092 & -73.697 \\
\hline 102 & 21.107 & 20.96 & -39.146 & 273 & -4.089 & -5.21 & -38.154 & 444 & 18.439 & 27.894 & -38.043 \\
\hline 103 & 27.428 & 36.224 & -16.841 & 274 & 4.401 & 12.954 & -29.901 & 445 & 2.919 & 3.209 & -51.912 \\
\hline 104 & 4.92 & 10.734 & -47.307 & 275 & -18.278 & -13.369 & -60.034 & 446 & 18.122 & 30.388 & -31.456 \\
\hline 105 & 40.398 & 48.063 & -1.555 & 276 & 1.066 & 9.52 & -43.449 & 447 & -16.815 & -17.299 & -65.073 \\
\hline 106 & 34.208 & 34.493 & -23.348 & 277 & -29.866 & -27.533 & -77.495 & 448 & -0.631 & 10.585 & -35.893 \\
\hline 107 & 14.385 & 22.983 & -31.546 & 278 & -33.224 & -21.345 & -64.023 & 449 & -9.719 & -10.711 & -58.851 \\
\hline 108 & -6.138 & -3.659 & -56.615 & 279 & -19.01 & -16.754 & -68.747 & 450 & -1.452 & -0.806 & -52.459 \\
\hline 109 & 13.421 & 25.764 & -32.68 & 280 & -11.497 & -4.076 & -49.382 & 451 & 11.13 & 21.948 & -38.978 \\
\hline 110 & 10.608 & 12.203 & -51.858 & 281 & -8.454 & -7.956 & -59.502 & 452 & -0.595 & 1.021 & -52.041 \\
\hline 111 & 41.651 & 51.355 & -10.92 & 282 & -21.506 & -5.972 & -60.336 & 453 & 14.412 & 22.074 & -42.34 \\
\hline 112 & 23.787 & 21.153 & -36.582 & 283 & -18.979 & -15.974 & -66.751 & 454 & -2.391 & -0.237 & -50.466 \\
\hline 113 & -7.742 & 5.5 & -48.821 & 284 & -28.588 & -12.655 & -66.104 & 455 & 6.995 & 15.628 & -44.831 \\
\hline 114 & 50.7 & 44.688 & -5.593 & 285 & -29.914 & -27.85 & -84.55 & 456 & -15.354 & -15.879 & -63.694 \\
\hline 115 & 13.994 & 19.963 & -35.806 & 286 & -25.007 & -13.565 & -60.805 & 457 & 17.168 & 20.074 & -28.592 \\
\hline 116 & 47.332 & 45.588 & -6.981 & 287 & -22.639 & -17.084 & -65.025 & 458 & 4.372 & 3.154 & -54.413 \\
\hline 117 & 28.627 & 38.683 & -46.797 & 288 & -0.739 & 6.096 & -43.443 & 459 & 39.485 & 46.955 & -25.315 \\
\hline 118 & 42.447 & 36.076 & -15.481 & 289 & -44.227 & -38.602 & -80.452 & 460 & -21.38 & -20.69 & -74.51 \\
\hline 119 & 9.248 & 16.241 & -53.265 & 290 & -39.029 & -20.609 & -69.247 & 461 & 5.984 & 18.765 & -31.767 \\
\hline 120 & 39.652 & 35.304 & -12.046 & 291 & -1.809 & 2.1 & -51.589 & 462 & -19.747 & -18.298 & -71.033 \\
\hline 121 & -3.7 & 6.984 & -53.04 & 292 & -37.83 & -25.972 & -73.302 & 463 & -6.262 & -0.074 & -52.764 \\
\hline 122 & 43.361 & 41.179 & -19.838 & 293 & 6.769 & 5.23 & -36.044 & 464 & -22.373 & -20.524 & -72.373 \\
\hline 123 & 10.74 & 24.179 & -35.67 & 294 & -49.27 & -38.456 & -77.943 & 465 & -2.408 & 1.942 & -46.797 \\
\hline 124 & 34.059 & 34.058 & -16.449 & 295 & -17.351 & -14.902 & -53.135 & 466 & 13.678 & 14.77 & -38.191 \\
\hline 125 & 17.004 & 25.293 & -42.947 & 296 & -43.623 & -30.306 & -73.594 & 467 & -10.218 & 1.807 & -52.354 \\
\hline 126 & 33.648 & 31.211 & -25.154 & 297 & -5.377 & -3.051 & -40.527 & 468 & 31.524 & 27.773 & -14.733 \\
\hline 127 & 21.116 & 34.21 & -33.241 & 298 & -41.282 & -30.973 & -80.2 & 469 & -9.489 & 3.273 & -54.569 \\
\hline 128 & 24.39 & 25.218 & -28.145 & 299 & 3.56 & 1.506 & -40.905 & 470 & 28.584 & 23.338 & -18.177 \\
\hline 129 & -24.201 & -16.709 & -51.283 & 300 & -47.661 & -38.478 & -84.553 & 471 & -10.509 & 1.853 & -61.5 \\
\hline 130 & -25.717 & -14.392 & -57.384 & 301 & -4.423 & -7.749 & -42.462 & 472 & 30.619 & 25.352 & -17.125 \\
\hline 131 & 0.184 & 1.183 & -34.224 & 302 & -33.466 & -24.377 & -64.649 & 473 & -13.895 & -7.228 & -58.725 \\
\hline 132 & -31.167 & -13.663 & -57.059 & 303 & -12.469 & -12.393 & -59.153 & 474 & 3.244 & 0.465 & -48.17 \\
\hline 133 & 4.304 & 3.644 & -38.563 & 304 & -20.596 & -12.471 & -57.468 & 475 & -18.507 & -11.664 & -63.482 \\
\hline 134 & -9.488 & 3.362 & -38.91 & 305 & 5.188 & 3.724 & -37.103 & 476 & 23.181 & 16.63 & -34.094 \\
\hline 135 & 30.886 & 31.915 & -14.919 & 306 & -18.578 & -5.08 & -43.975 & 477 & -18.664 & -5.799 & -80.036 \\
\hline
\end{tabular}


WSRC-TR-2002-00318, Rev. 0

\begin{tabular}{|c|c|c|c|c|c|c|c|c|c|c|c|}
\hline \multicolumn{4}{|c|}{$\log _{10}(\mathrm{Q} / \mathrm{K})$} & \multicolumn{4}{|c|}{$\log _{10}(\mathrm{Q} / \mathrm{K})$} & \multicolumn{4}{|c|}{$\log _{10}(\mathrm{Q} / \mathrm{K})$} \\
\hline FileNo & NAS & Zeolite & $\mathrm{K}_{\mathrm{sp}}$ & FileNo & NAS & Zeolite & $\mathrm{K}_{\mathrm{sp}}$ & FileNo & NAS & Zeolite & $\mathrm{K}_{\mathrm{sp}}$ \\
\hline 136 & -19.89 & -5.513 & -53.56 & 307 & -25.612 & -21.922 & -59.58 & 478 & 5.769 & 3.996 & -44.993 \\
\hline 137 & 10.192 & 9.685 & -26.341 & 308 & -31.024 & -21.21 & -57.981 & 479 & -18.146 & -11.371 & -67.914 \\
\hline 138 & -36.23 & -15.619 & -61.521 & 309 & -43.775 & -39.636 & -80.382 & 480 & 6.2 & 7.112 & -39.74 \\
\hline 139 & 32.331 & 28.581 & -12.277 & 310 & 7.055 & 12.557 & -36.502 & 481 & -8.935 & 1.81 & -57.568 \\
\hline 140 & 0.38 & 12.371 & -42.588 & 311 & -17.965 & -14.429 & -60.962 & 482 & -6.611 & -7.519 & -56.016 \\
\hline 141 & 27.245 & 25.916 & -10.907 & 312 & -15.065 & -3.902 & -52.825 & 483 & 14.33 & 19.186 & -30.137 \\
\hline 142 & -45.694 & -29.183 & -73.346 & 313 & -52.035 & -46.766 & -88.469 & 484 & -13.643 & -14.986 & -59.587 \\
\hline 143 & 9.898 & 8.621 & -22.413 & 314 & -1.141 & 13.633 & -31.364 & 485 & 14.524 & 15.047 & -30.931 \\
\hline 144 & -21.778 & -10.964 & -67.636 & 315 & -33.963 & -28.383 & -75.02 & 486 & -14.495 & -14.653 & -59.586 \\
\hline 145 & -24.045 & -19.186 & -62.663 & 316 & -22.908 & -7.253 & -52.475 & 487 & 17.44 & 24.331 & -25.555 \\
\hline 146 & 9.696 & 13.549 & -25.157 & 317 & -26.354 & -23.149 & -67.319 & 488 & -25.718 & -25.284 & -67.729 \\
\hline 147 & -27.838 & -23.526 & -56.921 & 318 & -28.541 & -13.725 & -54.778 & 489 & 8.845 & 12.297 & -38.153 \\
\hline 148 & 25.405 & 26.997 & -18.339 & 319 & -26.984 & -23.446 & -73.956 & 490 & -11.996 & -9.058 & -62.442 \\
\hline 149 & -13.349 & -8.302 & -57.748 & 320 & 4.58 & 7.905 & -31.989 & 491 & -2.5 & 6.588 & -46.952 \\
\hline 150 & 14.693 & 21.206 & -21.265 & 321 & -50.229 & -45.036 & -84.117 & 492 & -7.862 & -8.89 & -65.658 \\
\hline 151 & -3.002 & 3.735 & -39.185 & 322 & -26.797 & -19.816 & -69.249 & 493 & 9.128 & 19.402 & -32.473 \\
\hline 152 & 6.46 & 15.164 & -26.704 & 323 & 3.423 & 17.768 & -27.877 & 494 & -11.52 & -8.027 & -56.345 \\
\hline 153 & -13.779 & -10.062 & -54.955 & 324 & -30.578 & -23.83 & -64.86 & 495 & -8.651 & 5.157 & -49.853 \\
\hline 154 & 12.769 & 21.178 & -23.299 & 325 & -10.83 & 3.215 & -52.359 & 496 & 1.181 & 1.292 & -48.927 \\
\hline 155 & -22.39 & -17.299 & -52.662 & 326 & -35.872 & -32.047 & -80.482 & 497 & -1.955 & 2.365 & -41.263 \\
\hline 156 & -7.537 & 7.785 & -38.787 & 327 & -4.23 & 10.515 & -36.708 & 498 & 6.569 & 7.74 & -43.736 \\
\hline 157 & -19.913 & -16.003 & -49.335 & 328 & -12.814 & -12.736 & -53.682 & 499 & -21.605 & -14.663 & -73.448 \\
\hline 158 & 39.081 & 42.824 & -4.387 & 329 & -6.205 & 5.195 & -39.319 & 500 & 8.871 & 7.262 & -38.718 \\
\hline 159 & 2.588 & 4.85 & -44.265 & 330 & -44.492 & -40.96 & -79.861 & 501 & -15.112 & -7.109 & -71.435 \\
\hline 160 & -10.797 & 3.893 & -35.226 & 331 & -8.444 & -1.192 & -54.317 & 502 & 9.583 & 10.983 & -35.428 \\
\hline 161 & 17.857 & 16.434 & -19.351 & 332 & -50.395 & -44.395 & -80.275 & 503 & -10.414 & -6.323 & -58.949 \\
\hline 162 & -19.828 & -4.811 & -50.398 & 333 & -33.227 & -16.646 & -58.711 & 504 & 23.045 & 16.683 & -18.325 \\
\hline 163 & 37.547 & 36.283 & -10.24 & 334 & -16.787 & -16.488 & -62.291 & 505 & -19.491 & -4.897 & -60.145 \\
\hline 164 & -15.444 & 2.118 & -46.601 & 335 & 9.611 & 13.73 & -35.422 & 506 & -2.726 & -2.402 & -51.687 \\
\hline 165 & 2.286 & 2.525 & -35.423 & 336 & -58.74 & -50.969 & -88.493 & 507 & -18.871 & -3.133 & -64.026 \\
\hline 166 & -14.402 & 1.994 & -48.897 & 337 & -18.139 & -11.207 & -46.914 & 508 & 15.479 & 8.709 & -34.765 \\
\hline 167 & 1.892 & 7.015 & -35.692 & 338 & -16.591 & -16.698 & -48.43 & 509 & -35.005 & -20.745 & -78.252 \\
\hline 168 & -32.796 & -16.892 & -61.25 & 339 & -29.697 & -15.103 & -59.666 & 510 & 19.51 & 13.714 & -26.008 \\
\hline 169 & 33.578 & 29.776 & -11.813 & 340 & -15.293 & -13.584 & -51.197 & 511 & -14.38 & -7.732 & -58.856 \\
\hline 170 & -17.098 & 0.015 & -58.903 & 341 & -36.351 & -24.357 & -62.865 & 512 & 24.222 & 20.195 & -30.558 \\
\hline 171 & 7.592 & 10.152 & -31.34 & 342 & -4.749 & -5.802 & -41.8 & 513 & -15.505 & -5.95 & -58.351 \\
\hline
\end{tabular}


Comparison of the OLH composition space analysis at temperatures between $40^{\circ} \mathrm{C}$ and $180^{\circ} \mathrm{C}$ and between zero to $80 \%$ evaporation are overlayed in Figure 10 with the nominal SRS evaporator model developed for the $120-140^{\circ} \mathrm{C}$ operating temperature and $40 \%$ evaporation. The nominal model fits comfortably within the space defined by the OLH analysis, thereby validating the calculational method used for the model and the conditions over which it was developed.

On Figure 10 it should be noted that at a Ksp $\left(\log Q(N A S)_{25^{\circ} \mathrm{C}}\right.$ of -43.3 that values of $\log (\mathrm{Q} / \mathrm{K})_{\mathrm{NAS}}$ can be as large as +40 indicating a great deal of supersaturation with respect to $\mathrm{NAS}_{\text {gel }}$. This was evaluated and the design points in the superaturated range are primarily those at low $\mathrm{OH}^{-}$concentrations, e.g. values $<1 \mathrm{M} \mathrm{OH}^{-}$. This is a limitation of the model in that the solubility data used for the $\mathrm{NAS}_{\text {gel }}$ was solubility data at $8.5 \mathrm{M} \mathrm{OH}^{-}$. Therefore, the minimum $\mathrm{OH}^{-}$modeled should be truncated at $1 \mathrm{M} \mathrm{OH}^{-}$. Other than this minimal limit, only the maximums given in Table $\mathrm{X}$ need to be considered during application of the model to the prediction of $\mathrm{NAS}_{\text {gel }}$ formation. Any additional minimum concentrations of major components will be addressed in (Part V) if the absence of a component such as Al causes a phase other than $\mathrm{NAS}_{\text {gel }}$ to precipitate and/or a different phase boundary to be intersected. 
WSRC-TR-2002-00318, Rev. 0

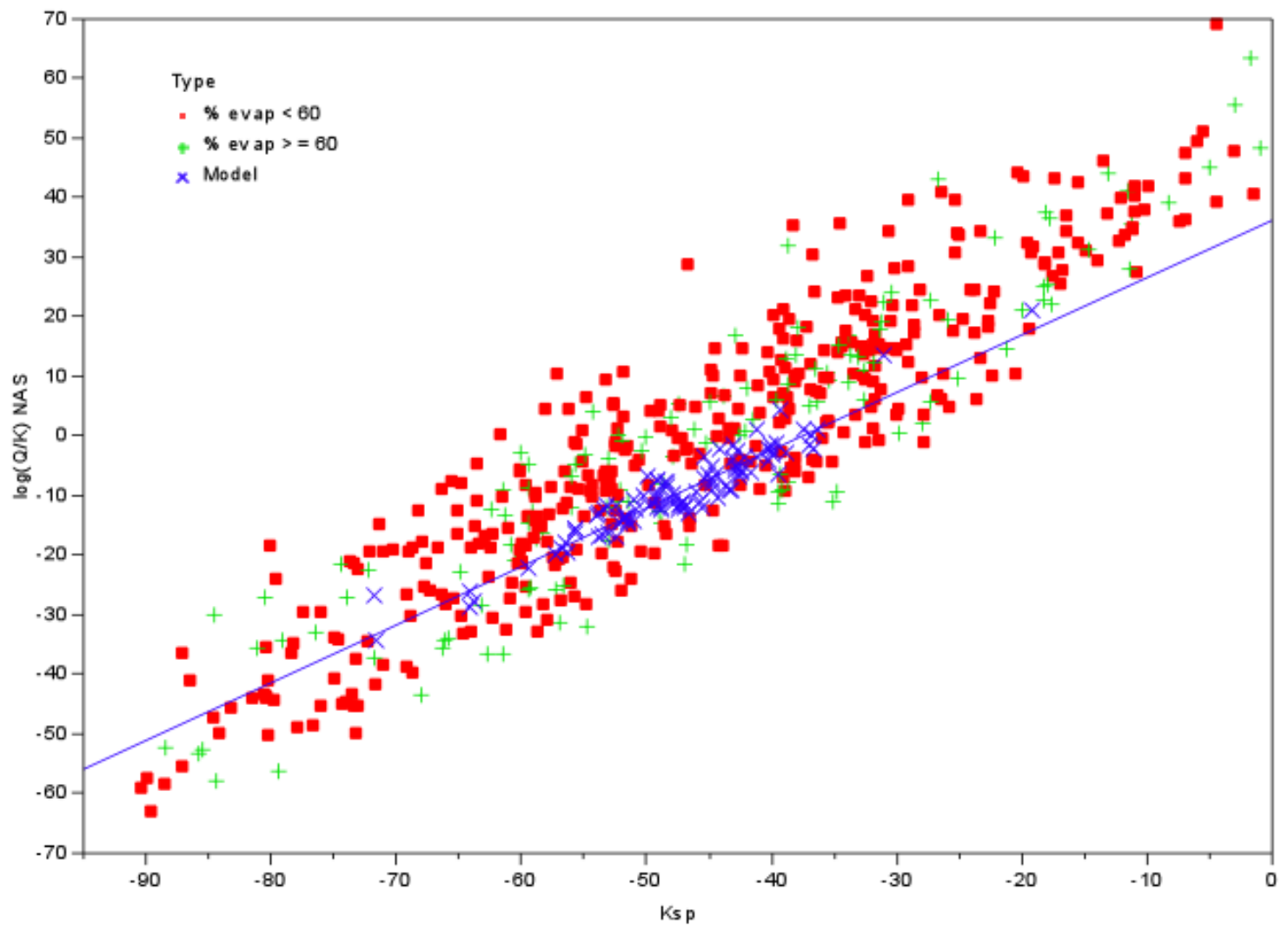

Figure 10. Comparison of the OLH composition space analysis at temperatures of $40^{\circ} \mathrm{C}$ $180^{\circ} \mathrm{C}$, at evaporations spanning zero to $80 \%$ compared to the SRS evaporator nominal model at $120-140^{\circ} \mathrm{C}$ operating temperature and $40 \%$ evaporation. 


\section{WSRC-TR-2002-00318, Rev. 0}

\subsection{RECENT TANK DATA}

The recent tank data discussed in Section 9.0 of this study is overlain on the model from Part $\mathrm{I}^{3}$ of this study. This data was not used to generate a new model, only for confirmatory understanding of the recent SRS Evaporator operations in light of the nominal evaporator model.

The recent tank data from February 2001 to June 2002 is shown on the nominal evaporator process control model in Figure 11. The data shown in deep purple is the recent data for all tanks. The deep purple Y's and X' are for Tanks 30 and 32, respectively. The solid purple squares are Tanks 43 and Tank 38. All of the data for the SRS 2H Evaporator feed tank (Tank 43) is labeled by date since the tank solutions analyzed were not fed to the 2H Evaporator until October, 2001 (after the evaporator was cleaned of aluminosilicate scale). The purple +'s and z's are Tanks 46 and 26, respectively. All of the data indicated in purple was analyzed by the F-Area laboratory. The orange colored Y's and X's for Tanks 30 and 32 are the February 2002 and June 2002 samples analyzed at SRTC.

Several interesting conclusions can be drawn from Figure 11 about recent processing history in the SRS 2H Evaporator system. It is obvious from the trends shown in

Figure 11 that the solutions decreased in supersaturation with time as long as the SRS $2 \mathrm{H}$ Evaporator was inoperable. The sample analyzed on 5/16/01 had a $\log \mathrm{Q}(\mathrm{NAS})_{25^{\circ} \mathrm{C}}$ of 36.9 , much more positive than the -43.3 process control limit set by sample FTF-046 from Tank 46. This corresponded to a calculated $\log (\mathrm{Q} / \mathrm{K})_{\mathrm{NAS}}$ of +0.7 . By $7 / 04 / 01$ the $\log \mathrm{Q}(\mathrm{NAS})_{25^{\circ} \mathrm{C}}$ of the Tank 43 solutions had dropped to -60.4 and the $\log (\mathrm{Q} / \mathrm{K})_{\mathrm{NAS}}$ was 22.1. Moreover, by $9 / 27 / 01$ the $\log \mathrm{Q}(\mathrm{NAS})_{25^{\circ} \mathrm{C}}$ was -67.4 and $\log (\mathrm{Q} / \mathrm{K})_{\mathrm{NAS}}$ was -28.9 . This indicates that it only took two months for the saturated May 2001 solutions to react leaving the tank supernate undersaturated with respect to $\mathrm{NAS}_{\text {gel }}$ precipitation.

The decrease in supersaturation in Tank 43 continued as long as the tank was quiescent (through September 2001). Once the SRS 2H Evaporator began operation again the solutions, as given by the dates on Figure 11, have become more saturated with respect to NAS $_{\text {gel }}$. It should be noted that none of the Tank 43 solutions have reached the $\log \mathrm{Q}$ $(\mathrm{NAS})_{25^{\circ} \mathrm{C}}$ limit of -43.3 .

The data shown on Figure 11 with respect to the SRS 3H Evaporator system are also interesting. It shows an increase in the degree of supersaturation of the Tank 32 solutions with time, e.g. compare the purple X's and Y's analyzed by F-Area to the most recent solutions indicated by the orange X's and Y's analyzed by SRTC. While no feed tank solutions have violated the $\log \mathrm{Q}(\mathrm{NAS})_{25^{\circ} \mathrm{C}}$ limit of being more positive than -43.3 , several of the drop tank analyses have been more positive than -43.3 (Table XIII). When Equation 10 is used to calculate the $\log (\mathrm{Q} / \mathrm{K})_{\mathrm{NAS}}$ for the samples with more positive $\log \mathrm{Q}$ $(\mathrm{NAS})_{25^{\circ} \mathrm{C}}$ values than -43.3 (samples HTK-482 and HTK-508, it is clear that these samples were more supersaturated than $\log (\mathrm{Q} / \mathrm{K})_{\mathrm{NAS}}$ of -5.50 but at no time did the $\log$ $(\mathrm{Q} / \mathrm{K})_{\mathrm{NAS}}$ values become positive indicating supersaturation (Table XIII). 
WSRC-TR-2002-00318, Rev. 0

Table XIII. Recent Tank Data in the SRS 3H Evaporator System

\begin{tabular}{|c|c|c|c|}
\hline Tank & Sample & $\begin{array}{c}\log \mathbf{Q} \\
(\mathbf{N A S})_{\mathbf{2 5}^{\circ} \mathrm{C}}\end{array}$ & $\begin{array}{c}\text { Calculated } \log \\
(\mathbf{Q} / \mathbf{K})_{\text {NAS }}\end{array}$ \\
\hline Tank 30 (Drop) & HTK-505 & -44.15 & -6.36 \\
\hline Tank 30 (Drop) & HTK-506 & -44.46 & -6.66 \\
\hline Tank 30 (Drop) & HTK-507 & -44.64 & -6.83 \\
\hline Tank 32 (Feed) & HTK-480 & -44.43 & -6.63 \\
\hline Tank 32 (Feed) & HTK-481 & -44.14 & -6.35 \\
\hline Tank 32 (Feed) & HTK-482 & -41.42 & -3.71 \\
\hline Tank 32 (Feed) & HTK-508 & -42.46 & -4.73 \\
\hline Tank 32 (Feed) & HTK-509 & -44.46 & -6.66 \\
\hline Tank 32 (Feed) & HTK-511 & -45.84 & -8.00 \\
\hline
\end{tabular}

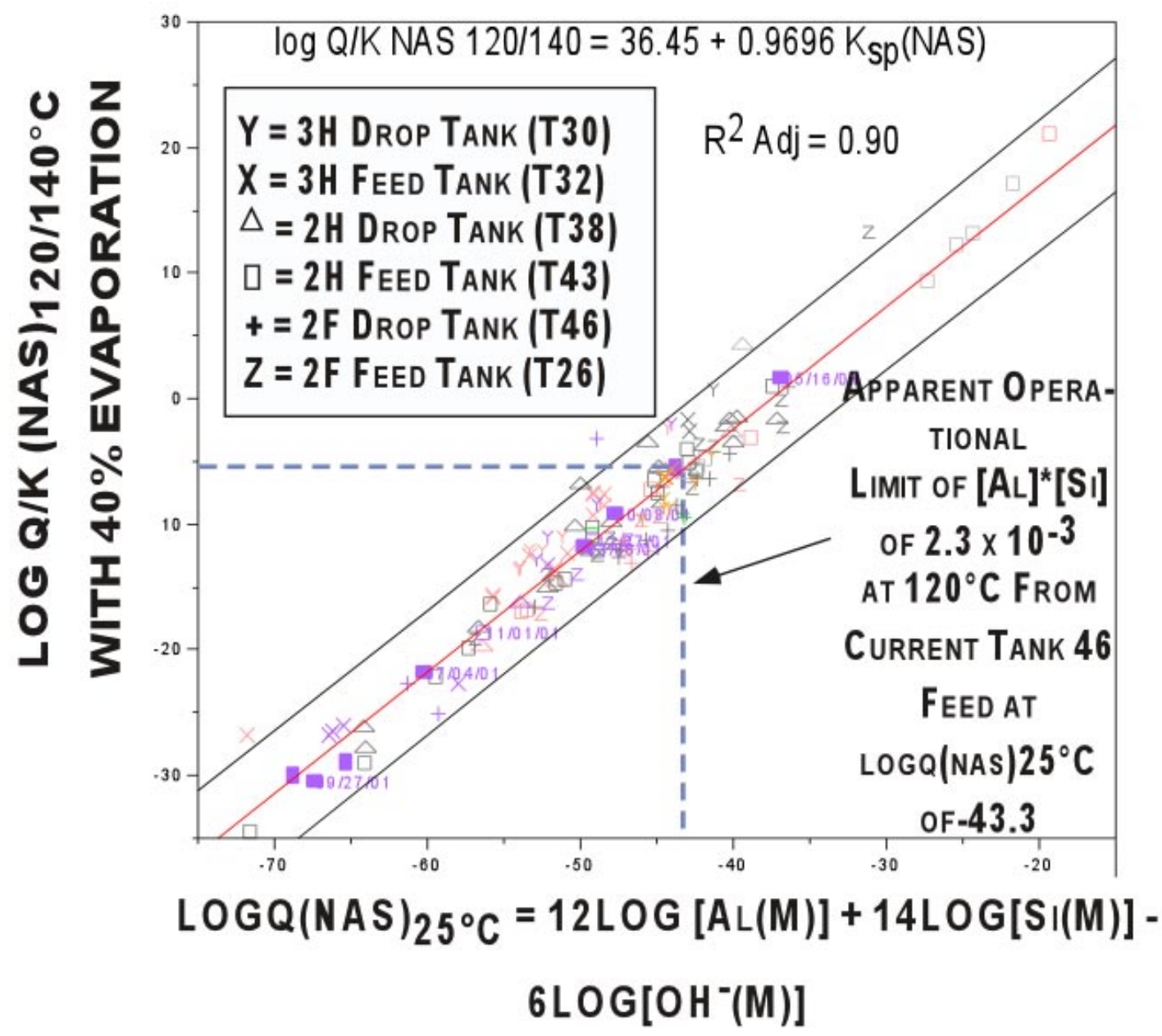

Figure 11. Recent Tank Data (February 2001-June 2002). 


\subsection{CONCLUSIONS}

The SRS evaporator model presented in Part I of this study ${ }^{3}$ is for the following nominal evaporator operating conditions:

- $40 \mathrm{wt} \%$ evaporation

- $120^{\circ} \mathrm{C}$ to $140^{\circ} \mathrm{C}$

The data and calculations presented in this follow on study are summarized below:

- temperature effects on the $\log (\mathrm{Q} / \mathrm{K})_{\text {NAS }}$ saturation index are negligible in the temperature range over which the SRS evaporators operate, e.g. 120$180^{\circ} \mathrm{C}$

- the elevated temperature $\log (\mathrm{Q} / \mathrm{K})_{\mathrm{NAS}}$ values fall within the $95 \%$ bias of the nominal evaporator process model, the errors associated with using the model developed for the pooled $120^{\circ} \mathrm{C} / 140^{\circ} \mathrm{C}$ data (Equation 10) for solutions being processed at $180^{\circ} \mathrm{C}$ is sufficiently accounted for

- the model does not apply above $180^{\circ} \mathrm{C}$ because of an intersecting stability field for $\mathrm{NaAlO}_{2}$ which creates an equilibrium boundary between this phase and $\mathrm{NAS}_{\text {gel }}$ instead of between $\mathrm{AlOOH}$ and $\mathrm{NAS}_{\mathrm{gel}}$

- the upper bounding $\log (\mathrm{Q} / \mathrm{K})_{\mathrm{NAS}}$ for the nominal evaporator model at 40 wt\% evaporation is just about at saturation, e.g. $\log (\mathrm{Q} / \mathrm{K})_{\mathrm{NAS}}$ is approximately zero $(-0.576)$ for solutions with a $\log \mathrm{Q}(\mathrm{NAS})_{25^{\circ} \mathrm{C}}$ of -43.3

- lower percentages of evaporation (10 wt \%, $20 \mathrm{wt} \%$, and $30 \mathrm{wt} \%$ ) have negative upper $95 \%$ bounding $\log (\mathrm{Q} / \mathrm{K})_{\mathrm{NAS}}$ values for solutions with a $\mathrm{K}_{\mathrm{sp}}$ of -43.3

- larger percentages of evaporation (50 wt \% and $60 \mathrm{wt} \%$ ) have positive upper $95 \%$ bounding $\log (\mathrm{Q} / \mathrm{K})_{\mathrm{NAS}}$ values for solutions with a $\mathrm{K}_{\mathrm{sp}}$ of -43.3

- the amount of evaporation can be correlated to $\log (\mathrm{Q} / \mathrm{K})_{\mathrm{NAS}}$ of -5.50 and still be conservative with respect to preventing aluminosilicate scale since the upper $95 \%$ error bounds for $\log \mathrm{Q}(\mathrm{NAS})_{25^{\circ} \mathrm{C}}=-43.3$ is $\log (\mathrm{Q} / \mathrm{K})_{\mathrm{NAS}}$ of 0.567

- process control based on varying amounts of evaporation is recommended based on $\log (\mathrm{Q} / \mathrm{K})_{\mathrm{NAS}}$ of -5.50 which gives a correlation between the saturation in the evaporator pot and the percent evaporation of

$$
\% \text { evaporation }=-285.64-7.47 \log \mathrm{Q}(\mathrm{NAS})_{25^{\circ} \mathrm{C}}
$$




\section{WSRC-TR-2002-00318, Rev. 0}

- an orthogonal latin hypercube (OLH) statistical design validates that the evaporator control model covers maximum composition ranges indicated below plus the temperature range $40^{\circ} \mathrm{C}$ to $180^{\circ} \mathrm{C}$ and evaporation ranges between 0 and $80 \%$

- recent tank data indicates that it only took about 2 months for the solutions in Tank 43 of the SRS 2H Evaporator system to react so that the supernates became undersaturated with respect to NAS $_{\text {gel }}$ (assuming that the tank remains quiescent)

- after the SRS 2H Evaporator system became operational again, the solutions became more supersaturated with respect to $\mathrm{NAS}_{\mathrm{gel}}$ but have not violated the $\log \mathrm{Q}(\mathrm{NAS})_{25^{\circ} \mathrm{C}}$ criteria of being more positive than -43.3 .

- the SRS 3H Evaporator system has become more saturated with respect to $\mathrm{NAS}_{\text {gel }}$ than in prior operating history and is operating close to the $\log \mathrm{Q}$ $(\mathrm{NAS})_{25^{\circ} \mathrm{C}}$ criteria of being more positive than -43.3 since many of the feed tank samples have $\log \mathrm{Q}(\mathrm{NAS})_{25^{\circ} \mathrm{C}}$ values of -44 while several drop tank samples have $\log \mathrm{Q}(\mathrm{NAS})_{25^{\circ} \mathrm{C}}$ values of -41 and -42

- recent tank data from the SRS 3H Evaporator system has verified the operational limit of -43.3 proposed in Part I of this study ${ }^{3}$

- the orthogonal latin hypercube (OLH) design demonstrated that the model predicts high degrees of supersaturation with respect to $\mathrm{NAS}_{\text {gel }}$ for solutions that have $\mathrm{OH}$ - concentrations $<1 \mathrm{M}$; this is a consequence of the fact that $\mathrm{NAS}_{\text {gel }}$ solubility used in GWB was for $8.5 \mathrm{M} \mathrm{OH}^{-}$solutions

- a minimum limit of $1 \mathrm{M} \mathrm{OH}^{-}$should be imposed for usage of the GWB model for SRS evaporators

- no other minimal limits are imposed on the usage of the GWB model; only the maximums given in Table $\mathrm{X}$ need to be considered during application of the model to the prediction of $\mathrm{NAS}_{\mathrm{gel}}$ formation

- any additional minimum concentrations of major components will be addressed in (Part V) if the absence of a component such as Al causes a phase other than $\mathrm{NAS}_{\text {gel }}$ to precipitate and/or a different phase boundary to be intersected. 


\subsection{ACKNOWLEDGEMENTS}

Kent Gilbreath from the SRS H-Area Tank farm is thanked for providing the data about sludge levels, feed pump levels, and operating temperatures of the SRS $3 \mathrm{H}$ from the Tank Farm morning reports. Ken Jones of the F-Area laboratory is acknowledged for discussions about the F-Area Si analytic methodology and dilution factors.

Many many thanks are due to David Hobbs and Bill Wilmarth of SRTC for their frequent and always helpful counsel.

This work was performed under contract No. DE-AC09-96SR18500 with the Department of Energy and co-funded by the Tank Focus Area under Technical Task Plan \# SR-1-9WT-31. 


\subsection{REFERENCES}

1 W. R. Wilmarth, C. J. Coleman, A. R. Jurgensen, W. M. Smith, J. C. Hart, W. T. Boyce, D. Missimer, C. M. Conley, "Characterization and Dissolution Studies of Samples from the 242-16H Evaporator,' WSRC-TR-2000-00038, Rev. 0 (January 31, 2000).

2 W. R. Wilmarth, C. J. Coleman, J. C. Hart, and W. T. Boyce, "Characterization of Samples from the 242-16H Evaporator Wall," WSRC-TR-2000-00089 (March 20, 2000).

3 C.M. Jantzen, J.E. Laurinat, and K.G. Brown "Thermodynamic Modeling of the SRS Evaporators: Part I. The 2H and 2F Systems (U),' WSRC-TR-200000293, Rev. 1 (April 4, 2002).

4 C.M. Jantzen, J.E. Laurinat, and K.G. Brown "Thermodynamic Modeling of the SRS Evaporators: Part II. The 3H System (U)," WSRC-TR-2001-00155, Rev. 1 (April 8, 2002).

5 C.M. Jantzen and J.M. Pareizs, "Thermodynamic Modeling of the SRS Evaporators: Part IV. Incorporation of SRS Evaporator Specific Aluminosilicate Solubility Data,”WSRC-TR-2002-00330 (August 1, 2002).

$6 \quad$ J.M. Pareizs and C.M. Jantzen, “Thermodynamic Modeling of the SRS Evaporators: Part V. Validation,” WSRC-TR-2002-00331 (September 1, 2002).

7 W. R. Wilmarth, S. D. Fink, D. T. Hobbs, M. S. Hay, "Characterization and Dissolution Studies of Samples from the 242-16H Evaporator Gravity Drain Line," WSRC-TR-97-0326, Rev.0 (October 16, 1997).

8 C.S. Boley, M.C. Thompson, W.R. Wilmarth, and K.G. Brown, "Technical Basis for the 242-16H Evaporator Cleaning Process,' WSRC-TR-2000-00211, Rev. 1 (November, 2000).

9 Iman, R. L. and J. C. Helton, “An Investigation of Uncertainty and Sensitivity Analysis Techniques for Computer Models,” Risk Analysis, 8, 71-90, 1988.

10 Sacks, J., S. B. Schiller, and W. J. Welch, “Designs for Computer Experiments," Technometrics, 31, 41-47,1989.

11 Sacks, J., W. J. Welch, T. J. Mitchell, and H. P. Wynn, "Design and Analysis of Computer Experiments,’ Statistical Science, 4, 409-435, 1989. 
12 Ye, K. Q., “Orthogonal Column Latin Hypercubes and Their Application in Computer Experiments," Journal of the American Statistical Association, 93, 1430-1439, 1998.

13 K.G. Brown, "Designed SRS Evaporator Experiments Using Geochemist's Workbench,” SRTC-GPD-2002-00058 (May 15, 2002).

14 R.M. Barrer, "Hydrothermal Chemistry of Zeolites," Academic Press,London (1982).

15 The American Heritage Dictionary, Second College Edition, Houghton Mifflin Co., Boston, MA, (1982).

16 G.M. Barrow, "Physical Chemistry," 2nd edition, McGraw-Hill Book Company, New York, 843pp., (1966).

17 M.C. Barnes, J.A. Mensah, and A.R. Gerson, "The Mechanism of the Sodaliteto-Cancrinite Phase Transformation in Synthetic Spent Bayer Liquor,' Microporous and Mesoporous Materials, 31, 287-302 (1999).

18 A.R. Gerson and K. Zheng, "Bayer Process Plant Scale: Transformation of Sodalite to Cancrinite,’ J. of Crystal Growth, 171, 209-218 (1997).

19 R. M. Barrer, J. W. Baynham, F. W. Bultitude, and W. M. Meier, "Hydrothermal Chemistry of the Silicates. Part V23I, Low-Temperature Crystal Growth of Aluminosilicates, and of Some Gallium and Germanium Analogues," 195-208 (1959).

20 T. Ejaz A.G. Jones and P. Graham, "Solubility of Zeolite-A and Its Amorphous Precursor Under Synthesis Conditions,” J. Chem. Eng. Data, 44, 574-576 (1999).

21 J.C. Buh. And J. Lons, "Synthesis and Crystal Structure of Nitrate Enclathrated Sodalite, Na8[AlSiO4]6(NO3)2," Journal of Alloys and Compounds, v.235, 41-47 (1996).

22 W. R. Wilmarth, D. D. Walker, S. D. Fink, "Sodium Aluminosilicate Formation in Tank 43H Simulants,” WSRC-TR-97-00389, Rev. 0 (November 15, 1997).

23 H. A. Gasteiger, W. J. Frederick, and R. C. Streisel, "Solubility of Aluminosilicates in Alkaline Solutions and a Thermodynamic Equilibrium Model,’ Ind. Eng. Chem. Res., 31, 1183-1190 (1992).

24 B. Subotic, D. Skrtic, I. Smit, L. Sekovanic, "Transformation of Zeolite-A into Hydroxysodalite," J. Crystal Growth, 50, 498-508 (1980). 
25 S. Bosnar and B. Subotic, "Mechanism and Kinetics of the Growth of Zeolite Microcrystals; Part I. Influence of the Alkalinity of the System on the Growth of Zeolite-A Microcrystals," Microporous and Misoporous Materials, 28, 483-493 (1999).

26 A.J. Mattus, C.H. Mattus, and R.D. Hunt, "Kinetic Testing of Nitrate-Based Sodalite Formation Over the Temperature Range of 40 to $100^{\circ}$ C," U.S. DOE Report ORNL/TM-2001, Oak Ridge National Laboratory, UT-Battelle, LLC, Oak Ridge, TN (April 13, 2001).

27 R.K. Iler, "The Colloid Chemistry of Silica and Silicates," Cornell University Press, Ithaca, NY, 324pp. (1955).

28 A.K. Varshneya, "Fundamentals of Inorganic Glasses," Academic Press, Inc., New York, 570pp. (1994).

29 S.M. Budd, "The Mechanisms of Chemical Reaction Between Silicate Glass and Attacking Agents,” Phys. Chem. Glasses, 2[4], 111-114 (1961).

30 S.V. Mattigod and B.P. McGrail, "Estimating the Standard Free Energy of Formation of Zeolites Using the Polymer Model," Microporous and Mesoporous Materials, 27, 41-47 (1999).

31 D.E. White, W.W. Brannock, and K.J. Murata, "Silica in Hot-Spring Waters," Geochim. Cosmochim. Acta, 10, 27-59 (1956).

32 W.R. Wilmarth “Tank 30H Sample Analysis,” SRT-LWP-2002-00053 (may 29, 2002).

33 W.R. Wilmarth "Tank 30H and 32H Sample Analysis," SRTC-LWP-200200058 (June 19, 2002).

34 D.D. Walker and C.J. Coleman, "Densities and Weight\% Solids of Simulated Salt Solutions," WSRC-TR-91-176 (April 1991).

35 C. Coleman, personal communication

36 C.F. Baes, Jr. and R.E. Mesmer, “The Hydrolysis of Cations," John Wiley \& Sons, New York, 489pp. (1976).

37 S. Sjoberg, L.Ohman, N. Ingri, "Equilibrium and Structural Studies of Silicon(IV) and Aluminum(III) in Aqueous Solution. 11. Polysilicate Formation in Alkaline Aqueous Solution. A Combined Potentiometric and 29Si NMR Study,” Acta Chemica Scandinavica , A39, 93-107 (1985). 
38 I. Grenthe, et. al., "Chemical Thermodynamics of Uranium," North Holland, New York (1992).

39 R.H. Busey, R.E. Mesmer, "Ionization Equilibria of Silicic Acid and Polysilicate Formation in Aqueous Sodium Chloride Solutions to $300^{\circ} \mathrm{C}$," Inorg. Chem., 16, 2444-2450 (1977).

40 A.S. Russell, J.D. Edwards, and C.S. Taylor, "Solubility and Density of Hydrated Aluminas in NaOH Solutions," J. of Metals, p.1123-1128 (October, 1955).

41 D.A. Reynolds and D.L. Herting, "Solubilities of Sodium Nitrate, Sodium Nitrite, and Sodium Aluminate in Simulated Nuclear Waste," U.S. DOE Report, RHO-RE-SST-14P, Westinghouse Hanford Company, Richland, WA (September, 1984). 